UNIVERSIDADE DE SÃO PAULO

INSTITUTO DE PSICOLOGIA

KAREN CRISTINA PAGLIUSO WOHLERS

Ação da acupuntura nos sintomas motores e não motores da Doença de Parkinson.

São Paulo 
UNIVERSIDADE DE SÃO PAULO

INSTITUTO DE PSICOLOGIA

KAREN CRISTINA PAGLIUSO WOHLERS

\section{Ação da acupuntura nos sintomas motores e não motores da Doença de Parkinson.}

Trabalho apresentado ao Instituto de Psicologia da Universidade de São Paulo como parte do exame geral de defesa de titulo.

Nível: Doutorado

Área de Concentração: Neurociências e Comportamento

Orientador: Luiz Roberto Giorgetti de Britto

São Paulo 
AUTORIZO A REPRODUÇÃO E DIVULGAÇÃO TOTAL OU PARCIAL DESTE TRABALHO, POR QUALQUER MEIO CONVENCIONAL OU ELETRÔNICO, PARA FINS DE ESTUDO E PESQUISA, DESDE QUE CITADA A FONTE.

Catalogação na publicação Biblioteca Dante Moreira Leite

Instituto de Psicologia da Universidade de São Paulo

Dados fornecidos pelo(a) autor(a)

Wohlers, Karen Cristina Pagliuso

Ação da acupuntura nos sintomas motores e não motores da Doença de Parkinson. / Karen Cristina Pagliuso Wohlers; orientador Luiz Roberto Giorgetti de Britto. --

São Paulo, 2019.

$90 \mathrm{f}$.

Tese (Doutorado - Programa de Pós-Graduação em Neurociências e Comportamento) -- Instituto de Psicologia, Universidade de São Paulo, 2019.

1. Acupuntura. 2. Doença de Parkinson. 3. Sintomas. I. Britto, Luiz Roberto Giorgetti de, orient. II. Título. 
WOHLERS, K. C. P. Ação da acupuntura nos sintomas motores e não motores da Doença de Parkinson. Tese apresentada ao Instituto de Psicologia da Universidade de São Paulo para obtenção do título de doutor em Neurociências e Comportamento.

Aprovado em:

Banca Examinadora

Prof. Dr. Instituição:

Julgamento: Assinatura:

Prof. Dr. Instituição:

Julgamento: Assinatura:

Prof. Dr. Instituição:

Julgamento: Assinatura:

Prof. Dr. Instituição:

Julgamento: Assinatura:

Prof. Dr. Instituição:

Julgamento: Assinatura: 


\section{AGRADECIMENTOS}

A Deus por ter me dado toda a força e serenidade durante esta caminhada.

Aos meus pais, por todo o apoio, estrutura e amor para que eu chegasse até este momento.

Ao meu amigo, Leonardo Rocha Fontes, um incentivador desde o início desta jornada, nunca me deixando desistir dos meus sonhos.

Ao Prof Dr. Luiz Roberto Giorgetti de Britto por toda dedicação, paciência e suporte durante este período, sendo mais que somente um orientador, e sim como um pai nesta jornada.

Ao Instituto de psicologia da Universidade de São Paulo por todo suporte para que esta pesquisa se realizasse.

$\mathrm{E}$ a todos aqueles que de alguma forma contribuíram direta ou indiretamente com este momento de aprendizado. 
"O mundo é um lugar perigoso de se viver, não por causa daqueles que fazem o mal, mas sim por causa daqueles que observam e deixam o mal acontecer".

Albert Einstein 


\section{Resumo}

WOHLERS, K. C. P. Ação da acupuntura nos sintomas motores e não motores da Doença de Parkinson. 2019. 90f. Tese (doutorado) - Instituto de Psicologia, Universidade de São Paulo, São Paulo, 2019.

A Doença de Parkinson é a segunda doença neurodegenerativa mais comum que atinge os indivíduos acima dos 50 anos, acometendo de $1 \%$ a $5 \%$ da população mundial, tornando-se um problema de saúde pública devido ao avanço da expectativa de vida da população. Dentre os tratamentos utilizados temos a utilização de medicações e terapias diversas, dentre elas a Acupuntura (ACP) que é uma técnica milenar da medicina chinesa que utiliza a inserção de agulhas em pontos específicos corporais. No presente trabalho foram realizadas cinco sessões de acupuntura, uma vez por semana, em um grupo de sete pacientes escolhidos de forma aleatória. Foram mensurados escala visual analógica de dor, UPDRS parte III, mini mental, escala de sintomas não motores e questionário de qualidade de vida, tais avaliações mensuram de forma quantitativa os sintomas motores e não motores da doença de Parkinson. Foram utilizados teste T-student para dados parados, teste de Wilcoxon e ANOVA dependendo do dado encontrado. Após a análise estatística foram detectadas diferenças significantes entre antes e após a realização da quinta sessão, sugerindo assim melhora dos scores da dor, dos sintomas motores, dos sintomas não motores e da qualidade de vida desses pacientes.

Palavras - chaves: Acupuntura, Doença de Parkinson, sintomas não motores 


\begin{abstract}
WOHLERS, K. C. P. Ação da acupuntura nos sintomas motores e não motores da Doença de Parkinson. 2019. 90f Tese (doutorado) - Instituto de Psicologia, Universidade de São Paulo, São Paulo, 2019.
\end{abstract}

Parkinson's disease is the second most common neurodegenerative disease that affects individuals over 50 years of age, affecting $1 \%$ to $5 \%$ of the world population, becoming a public health problem due to the advancement of life expectancy of the population. Among the treatments used are the use of medications and various therapies, among them Acupuncture (ACP), which is an ancient technique of Chinese medicine that uses the insertion of needles at specific bodily points. In the present study, five acupuncture sessions were performed once a week in a group of seven randomly selected patients. The visual analog pain scale, UPDRS part III, mini mental, non-motor symptom scale and quality of life questionnaire were measured. These evaluations quantitatively measure the motor and non-motor symptoms of Parkinson's disease. T-student test was used for stopped data, Wilcoxon test and ANOVA depending on the data found. After the statistical analysis, significant differences were detected between before and after the fifth session, suggesting an improvement in pain scores, motor symptoms, non-motor symptoms and quality of life of these patients.

Key words: Acupuncture, Parkinson 's disease, non - motor symptoms 


\section{Lista de figuras}

1. Figura 1: Mecanismos propostos para a patogênese da doença de Parkinson...17

2. Figura 2: Localização do ponto IG4 (anexo 9)............................................88

3. Figura 3: Localização do ponto F3 (anexo9).............................................88

4. Figura 4: Localização do ponto VB34 (anexo 9)..........................................89

5. Figura 5: Localização do ponto BP6 (anexo 9).......................................... 89

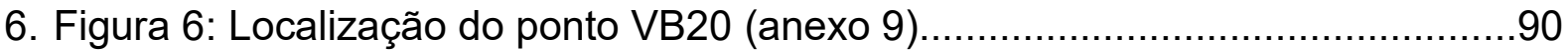

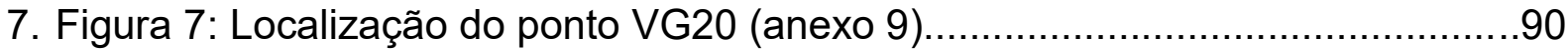




\section{Lista de tabelas}

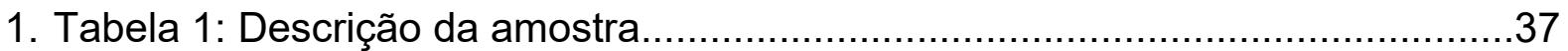

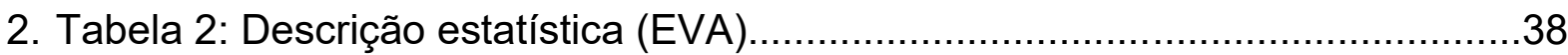

3. Tabela 3: Descrição estatística (UPDRS - parte III)..................................40

4. Tabela 4: Descrição estatística (mini mental) ............................................41

5. Tabela 5: Descrição estatística (NMSS) ..................................................42

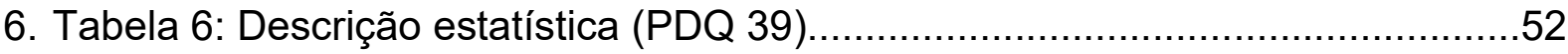




\section{Lista de gráficos}

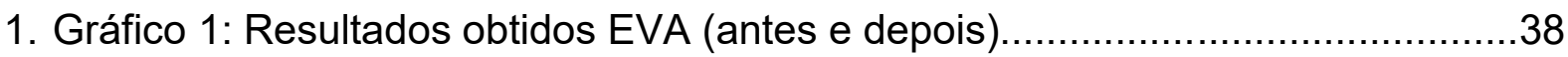

2. Gráfico 2: Resultados obtidos após estatística (EVA)......................................38

3. Gráfico 3: Resultados obtidos UPDRS parte III (antes e depois)...........................39

4. Gráfico 4: Resultados obtidos UPDRS parte III (antes e depois)..........................39

5. Gráfico 5: Resultados obtidos após estatística (UPDRS parte III).......................40

6. Gráfico 6: Resultados obtidos mini mental (antes e depois) ...............................41

7. Gráfico 7: Resultados obtidos após estatística (mini mental).............................41

8. Gráfico 8: Resultados obtidos NMSS - domínio cardiovascular (antes e depois)

9. Gráfico 9: Resultados obtidos após estatística (NMSS - domínio

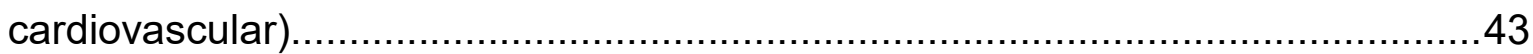

10. Gráfico 10: Resultados obtidos NMSS - domínio sono e fadiga (antes e depois)

11. Gráfico 11: Resultados obtidos após estatística (NMSS - domínio sono e fadiga)

12. Gráfico 12: Resultados obtidos NMSS - domínio humor e cognição (antes e depois)

13. Gráfico 13: Resultados obtidos após estatística (NMSS - domínio humor e cognição)

14. Gráfico 14: Resultados obtidos NMSS - domínio percepção e alucinação (antes e depois)

15. Gráfico 15: Resultados obtidos após estatística (NMSS - domínio percepção e alucinação).

16. Gráfico 16: Resultados obtidos NMSS - domínio atenção e memória (antes e depois)

17. Gráfico 17: Resultados obtidos após estatística (NMSS - domínio atenção e memória).

18. Gráfico 18: Resultados obtidos NMSS- domínio gastrointestinal (antes e depois).

19. Gráfico 19: Resultados obtidos após estatística (NMSS - domínio gastrointestinal) 
20. Gráfico 20: Resultados obtidos NMSS - domínio urinário (antes e

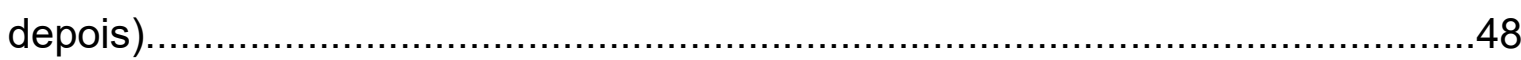

21. Gráfico 21: Resultados obtidos após estatística (NMSS - domínio urinário).......48

22. Gráfico 22: Resultados obtidos NMSS- domínio função sexual (antes e depois)...

23. Gráfico 23: Resultados obtidos após estatística (NMSS - domínio função sexual)

24. Gráfico 24: Resultados obtidos NMSS - domínio miscelânea (antes e depois)....49

25. Gráfico 25: Resultados obtidos após estatística (NMSS - domínio miscelânea). 50

26. Gráfico 26: Resultados obtidos NMSS - Total (antes e depois)...................... 50

27. Gráfico 27: Resultados obtidos após estatística (NMSS - Total)..................... 51

28. Gráfico 28: Resultados obtidos PDQ39 - domínio mobilidade (antes e depois).. 53

29. Gráfico 29: Resultados obtidos após estatística (PDQ39 - domínio mobilidade). 53

30. Gráfico 30: Resultados obtidos PDQ39 - domínio atividade de vida diária (antes e depois) 53

31. Gráfico 31: Resultados obtidos após estatística (PDQ39 - domínio atividade de vida diária)

32. Gráfico 32: Resultados obtidos PDQ39 - domínio bem estar emocional (antes e depois) 54

33. Gráfico 33: Resultados obtidos após estatística (PDQ39 - domínio bem estar emocional) 54

34. Gráfico 34: Resultados obtidos PDQ39 - domínio estigma (antes e depois)...... 55

35. Gráfico 35: Resultados obtidos após estatística (PDQ39 - domínio estigma).... 55

36. Gráfico 36: Resultados obtidos PDQ39 - domínio suporte social (antes e depois)

37. Gráfico 37: Resultados obtidos após estatística (PDQ39 - domínio suporte social). 56

38. Gráfico 38: Resultados obtidos PDQ39 - domínio cognição (antes e depois).... 56

39. Gráfico 39: Resultados obtidos após estatística (PDQ39 - domínio cognição).. 57

40. Gráfico 40: Resultados obtidos PDQ39 - domínio comunicação (antes e depois) 
41. Gráfico 41: Resultados obtidos após estatística (PDQ39 - domínio

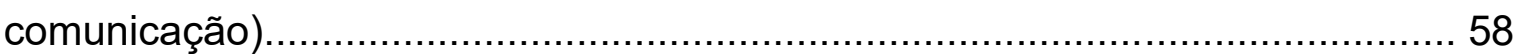

42. Gráfico 42: Resultados obtidos PDQ39 - domínio desconforto corporal (antes e

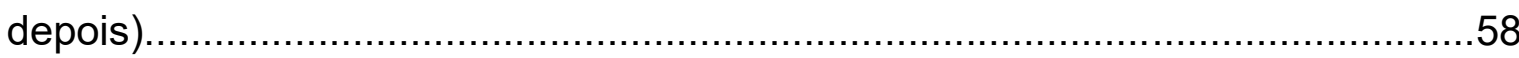

43. Gráfico 43: Resultados obtidos após estatística (PDQ39 - domínio desconforto corporal) .58

44. Gráfico 44: Resultados obtidos PDQ39 - Total (antes e depois) 59

45. Gráfico 45: Resultados obtidos após estatística (PDQ39 - Total). 59 


\section{Sumário}

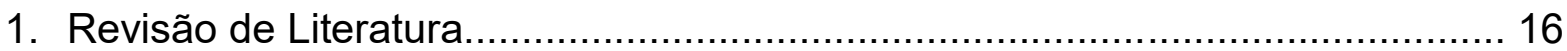

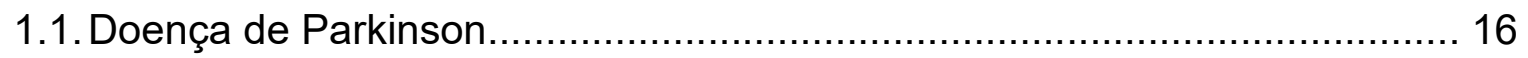

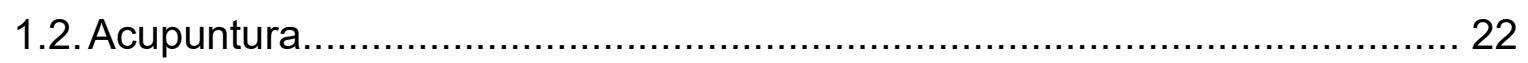

1.3. Acupuntura na DP baseada em evidências............................................. 26

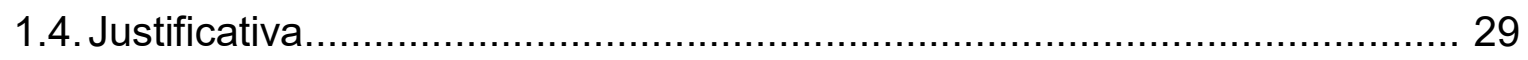

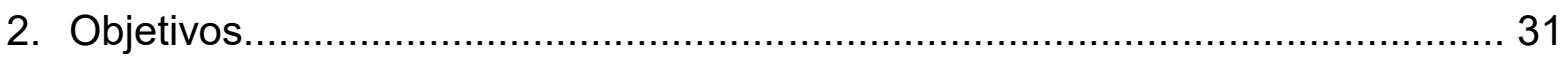

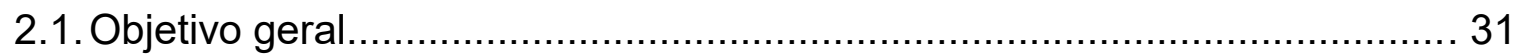

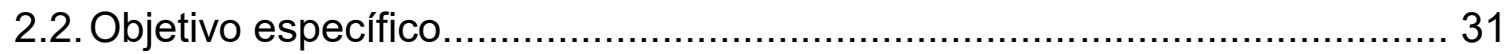

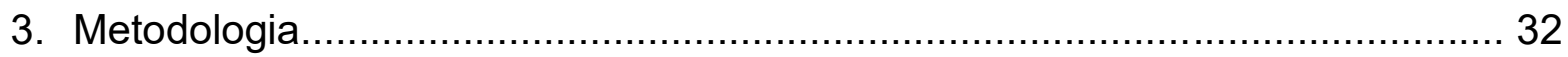

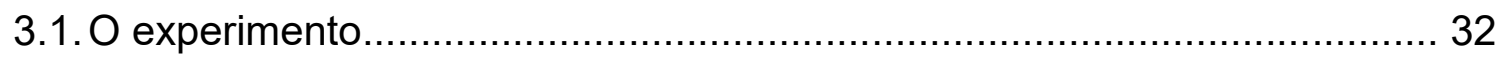

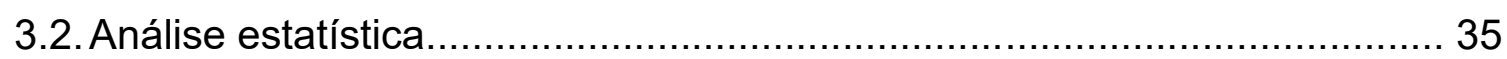

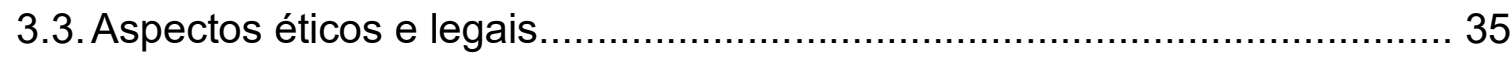

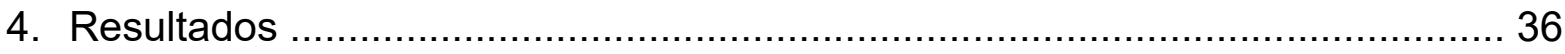

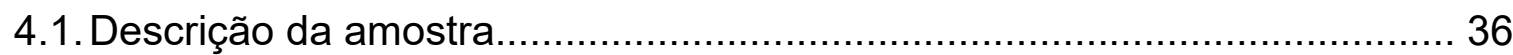

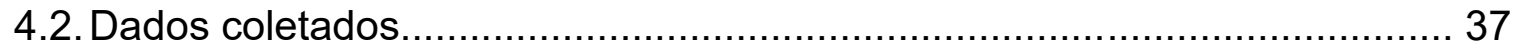

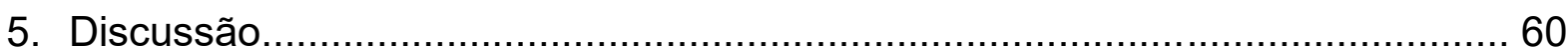

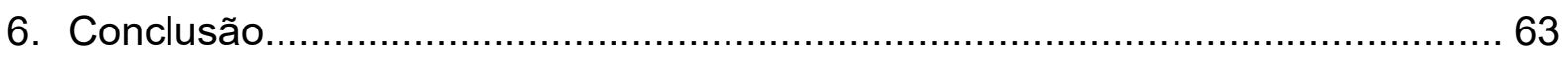

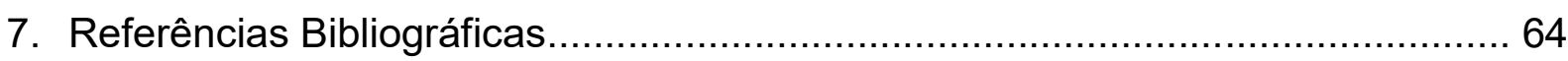

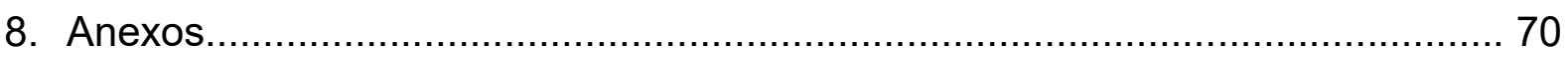




\section{Anexos}

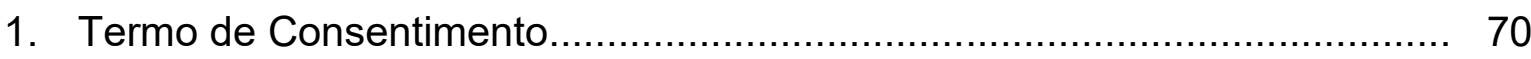

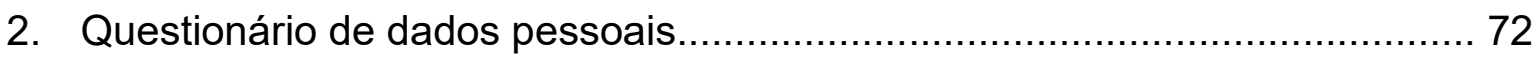

3. Escala Unificada para Doença de Parkinson............................................. 73

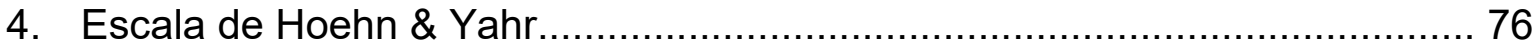

5. Escala de qualidade de vida para Doença de Parkinson............................. 77

6. Escala de sintomas não motores.......................................................... 83

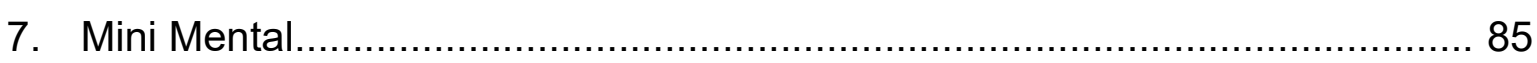

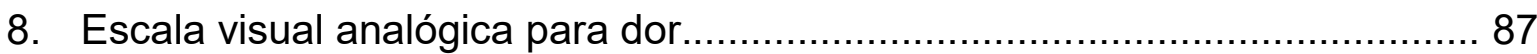

9. Figuras da localização dos pontos da acupuntura................................... 88 


\section{Revisão de literatura}

\subsection{Doença de Parkinson}

O avanço na expectativa de vida da população tem tornado as doenças neurológicas um problema de saúde pública. A doença de Parkinson (DP) é a segunda mais comum desordem neurodegenerativa que atinge indivíduos acima dos 50 anos, acometendo de $1 \%$ a $5 \%$ da população mundial (MILLER,O'CALLAGHAN, 2015; NAM KIM e col., 2013; TOOSIZADEH e col., 2015; WANG e col., 2011; WANG e col., 2013; YEO e col., 2014).

A descrição inicial da doença foi realizada pelo médico inglês James Parkinson em 1817, e tradicionalmente tem sido considerada como idiopática ou esporádica com etiologia complexa que envolve múltiplas influências como estilo de vida, genética e fatores ambientais. Apresenta como principal alteração patológica a perda progressiva e seletiva profunda dos neurônios catecolaminergicos da região compacta da substância negra (SNc) com consequente diminuição da concentração de dopamina (DA) no núcleo estriado, que leva a alterações na atividade dos núcleos da base, resultando na inabilidade do controle dos movimentos voluntários e subsequente distúrbios das funções motoras. Outra alteração patológica encontrada é a presença dos corpúsculos de Lewy (MILLER, O'CALLAGHAN, 2015; NAM KIM e col., 2013; KIM e col., 2011; YANG e col., 2011; WANG e col., 2011; WANG e col., 2013).

Biomarcadores ainda estão sendo pesquisados, para auxiliar o diagnóstico da doença, em diversos estágios além de prever riscos e suscetibilidade. Em análises post-mortem são encontrados a degeneração e morte de neurônios da substância negra, presença de agrupados proteicos citoplasmáticos,chamados corpos de Lewy, na SNc com presença de $\alpha$-synuclein ( $\alpha$-syn) e ubiquitina, sugerindo mecanismos de morte celular por apoptose (MILLER, O'CALLAGHAN, 2015; YANG e col., 2011; YEO, CHOI, HONG, LIM, 2013; ZENG e col., 2014; WANG e col., 2011).

A $\alpha$-syn é uma proteína tradicionalmente citoplasmática, mas esta visão tem sido alterada por sua presença em fluidos extracelulares como plasma e líquido 
cefalorraquidiano na DP. O mecanismo de secreção dessa proteína não é totalmente esclarecido, mas evidências apontam que suas fibrilas são liberadas no meio extracelular por uma exocitose não clássica. No meio extracelular podem se propagar e serem endocitadas por neurônios vizinhos ou células gliais, propagando e amplificando, assim, sinais degenerativos de célula para célula. As glias estão particularmente envolvidas na progressão das doenças neurodegenerativas por seu papel na comunicação celular e por evidências de acúmulos de agregados de $\alpha$-syn em astrócitos e oligodendrócitos. Esse aumento depositário, aparentemente, induz uma resposta precoce astrocitária e glial com importante resposta inflamatória que acelera os danos neuronais e a progressão da DP (DENG e col., 2015).

Outros achados identificaram alterações nas funções mitocondriais, aumento do stress oxidativo, disfunção lisossomal, agregação e degradação proteica, altos índices de marcadores de perioxidação lipídica, oxidação de DNA e distúrbios no equilíbrio do ferro. Todos esses achados (figura 1) podem ser importantes para elucidar a patogênese complexa da DP (MILLER, O'CALLAGHAN, 2015; YANG e col., 2011; YEO, CHOI, HONG, LIM, 2013;ZENG e col., 2014; WANG e col., 2011).

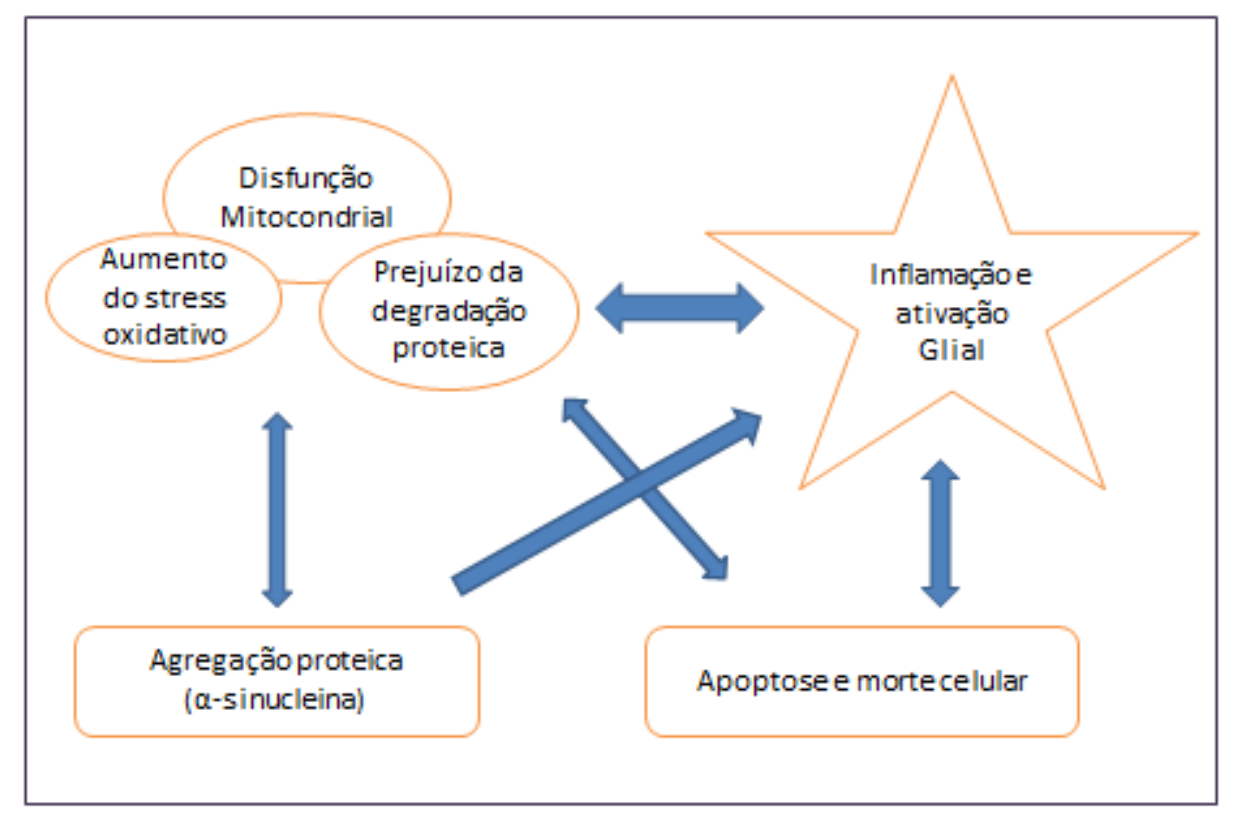

Figura 1- Mecanismos propostos para a patogênese da DP, esquema modificado de MILLER, O'CALLAGHAN, 2015. 
Suas principais características incluem o tremor de repouso, a rigidez e a bradicinesia, que são os chamados sintomas motores, e os sintomas não motores (NMS) como o déficit cognitivo, demência, distúrbios do sono, depressão, ansiedade, dores, fadiga e sintomas urinários. Os sintomas motores aparentemente não aparecem até que $50 \%$ a $60 \%$ de degeneração neuronal já tenha ocorrido, e tal fato pode ser explicado pela ocorrência de uma reserva neural ou mecanismos compensatórios (MILLER, O'CALLAGHAN, 2015). É uma doença complexa sistêmica que combina os sintomas motores e NMS, sendo que esses podem preceder em alguns anos às desordens motoras refletindo uma degeneração extra nigral antes da perda neuronal e se agravar com a progressão da doença, podendo até mesmo limitar os efeitos dos tratamentos motores. Quase $100 \%$ dos pacientes relatam ao menos um NMS, e alguns deles podem ser secundários à farmacoterapia, como psicose e transtornos de controle impulsivo. No momento do diagnóstico a prevalência de NMS é de $21 \%$ aumentando para $88 \%$ após sete anos de doença. A maioria das características não motoras está relacionada a alterações nas sínteses dos neurônios catecolaminérgicos. Alguns dos NMS, como a hiposmia (diminuição do olfato), podem aparecer antes mesmo dos sintomas motores por provável alteração no bulbo olfatório, no nervo olfatório e amígdala, estando presente em $90 \%$ dos pacientes e $10 \%$ dos que apresentam tal sintoma desenvolvem a doença em até dois anos (BONNET, 2012; CHUNG e col.; 2013; MARTIN, 2011; MILLER, O'CALLAGHAN, 2015; KHEDR, 2013; KOVÁCS, 2016; WATTANATHORN, SUTALANGKA, 2014; YEO e col., 2014).

A dor é um dos NMS mais frequentes que aumenta sua prevalência com a evolução da doença. A dor crônica está presente de $30 \%$ a $85 \%$ dos pacientes. A dor musculoesquelética é uma das dores mais comuns sendo resultante de uma combinação de fatores como a rigidez, deformidades e fatores mecânicos. A dor distônica ocorre em $40 \%$ dos pacientes e responde com as drogas dopaminérgicas assim como as dores por espasmos. As lesões nigro-estriatais dopaminérgicas modificam a percepção da dor e o processo de modulação da dor central é alterado com predomínio da hiperatividade dos circuitos nociceptivos (BONNET, 2012).

As desordens do sono acometem de $60 \%$ a $90 \%$ dos pacientes, dificuldade em pegar no sono, fragmentação do sono, pesadelos, sonhos vívidos, desordens do sono REM (de $25 \%$ a $50 \%$ dos pacientes) e a sonolência excessiva diurna $(20 \%$ a 
$50 \%$ dos pacientes) são as características mais observadas. Acredita-se que estes sintomas estão relacionados com a hipocinesia noturna, distonia noturna e logo pela manhã e noctúria, que podem impedir uma noite de sono reparadora (BONNET, 2012; CHUNG e col.; 2013; MARTIN, 2011;KHEDR, 2013; WATTANATHORN, SUTALANGKA, 2014; YEO e col., 2014).

Distúrbios de humor e apatia podem ocorrer em $30 \%$ a $40 \%$ dos pacientes sendo um dos maiores determinantes de redução de qualidade de vida. Sabendo-se que o sistema dopaminérgico é parte de um complexo sistema motivacional responsável por atribuir um caráter atrativo as coisas e estímulos, e que o portador de doença de parkinson apresenta tal sistema comprometido, podemos concluir que uma postura desencorajadora perante as tarefas é adotada nesses indivíduos. Desordens de humor e comportamento podem ser avaliadas regularmente durante as consultas com escalas específicas. A motivação e atos de decisão melhoram com a reposição farmacológica dopaminérgica (BONNET, 2012).

A depressão é o problema psiquiátrico mais comum, atingindo de $17 \%$ a $50 \%$ dos pacientes dependendo dos critérios clínicos utilizado no diagnóstico, mas sabese que ela ocorre pela piora da qualidade de vida e da incapacidade, associada à própria disfunção dos circuitos nigro-estriatais atingidos durante a doença (sistema noradrenérgico, serotoninérgico e dopaminérgico) tornando-se essencial uma avaliação individualizada. Importante destacar que a depressão se apresenta de forma diferente da forma clássica, na DP ocorre predomínio de características somáticas como falta de energia e lentificação psicomotora, com irritabilidade sem o sentimento de culpa ou de fracasso. Habitualmente os pacientes apresentam dificuldades em expressar suas emoções, pois consideram mais importante suas incapacidades motoras, dificultando o diagnóstico não motor depressivo (BONNET, 2012; SCHRAG, 2006; KIM, 2009).

A ansiedade geralmente presente nesses pacientes é considerada secundária ao quadro depressivo e acomete de $20 \%$ a $46 \%$; alguns fatores de risco são reportados como: gênero feminino, presença de flutuações motoras, história prévia de ansiedade e pacientes com idades mais jovens. Pode levar ao isolamento social e geralmente evolui para quadros depressivos (BONNET, 2012; MARTIN, 2011).

Outra característica comportamental pode estar associada a síndrome da desregulação de dopamina (DDS), que pode ser definida como o uso compulsivo de 
medicações dopaminérgicas associadas a importantes sintomas comportamentais e prejuízo da função social; e as desordens de controle impulsivo (ICDs), que são desordens de comportamento caracterizadas pela falta de resistência aos impulsos tais como jogos, compras e sexo, acometem de $15 \%$ a $20 \%$ dos pacientes. Acreditase que pacientes do sexo masculino e jovens tenham maior predisposição a desenvolver tais sintomas. As terapias dopaminérgicas podem levar a uma hiperestimulação da via meso-córtico-limbica resultando na ICD (BONNET, 2012).

O declínio cognitivo é frequentemente observado e associado à DP podendo se desenvolver de maneira insidiosa até cinco anos antes do diagnóstico da doença e progride ao longo do tempo avançando para a demência nas fases mais graves. As desordens cognitivas implicam na disfunção da substância negra e das vias nigro-estriatais, com desbalanço das vias corticais frontais causando uma síndrome cortico-frontal, que é caracterizada por uma déficit na escolha e planejamento de tarefas, déficit de memória e alteração nas representações internas dos estímulos visuais. A prevalência da demência ocorre entre $24 \%$ e $31 \%$ dos pacientes. Acredita-se que o nível educacional possa influenciar nas desordens cognitivas e de memória, sendo uma prevalência de $62 \%$ para analfabetos e $11 \%$ para indivíduos com ao menos seis anos de escolaridade (BONNET, 2012; KHEDR, 2013; MARTIN, 2011).

Alucinações ocorrem usualmente em estados normais de consciência, sem delírios, e apresentam curso crônico, ocorrendo em $22 \%$ a $38 \%$ dos pacientes e apresentam como fatores de risco a idade avançada, a severidade dos outros sintomas da doença, desordens do sono e desordens visuais. A psicose ocorre com maior risco nos casos de diagnóstico tardio da doença e com a utilização de altas doses de dopamina (BONNET, 2012).

A fadiga é reportada em $37 \%$ a $81 \%$ dos pacientes e afeta diretamente as atividades de vida diária. Desordens de transpiração podem levar a prejuízos físicos, emocionais e sociais secundários. Disfunções genitourinárias como aumento da frequência miccional e incontinência urinária ocorrem com frequência e relacionamse com a hiperatividade do músculo detrusor causada pela alteração dos circuitos do reflexo de micção normal. A constipação ocorre em mais de $50 \%$ dos pacientes e a salivação excessiva pode acometer $48 \%$ dos pacientes e levar a dificuldades de fala, alimentação e interação social. Disfunções sexuais (diminuição da libido, 
intercorrências sexuais, diminuição do orgasmo, diminuição da ejaculação e ereção) e hipotensão ortostática também frequentemente estão presentes em ao menos um terço dos pacientes (BONNET, 2012; KHEDR, 2013; MARTIN, 2011).

Geralmente os NMS não são frequentemente reportados e por tal motivo não recebem tanta atenção no tratamento clínico, mesmo influenciando amplamente na qualidade de vida do paciente e de seus cuidadores com o aumento da severidade da doença. Alguns pacientes relatam flutuações nos NMS assim como ocorre com os sintomas motores, tais flutuações podem levar a um grau ainda maior de incapacidade e estresse (BONNET, 2012; GARCIA, FERNANDEZ, 2013; KIM, 2009; KOVÁCS, 2016; LEONARDI, 2012; SOH, MORRIS, McGINLEY, 2011).

Importante ressaltar que qualidade de vida é um termo amplamente utilizado e refere-se às conotações fisiológicas sobre a satisfação em aspectos pessoais e padrões sociais; segundo a OMS é definida pela percepção individual da vida no contexto cultural e de valores em relação aos seus objetivos, expectativas e preocupações. Mas em estudos clínicos o que geralmente quer se avaliar é a chamada qualidade de vida relacionada à saúde (HRQoL), que descreve a percepção dos próprios pacientes sobre o impacto causado da doença em suas vidas e suas consequências (MARTIN, 2011; SOH, MORRIS, McGINLEY, 2011).

Em geral o diagnóstico de DP é realizado por exames clínicos sendo condicionado a presença de manifestações motoras; a utilização de exames de imagem como tomografia computadorizada por emissão de fóton único (SPECT), tomografia por emissão de pósitrons (PET), ressonância nuclear magnética (MRI) e sonografia transcraniana (TCS) podem contribuir com informações sobre a estrutura cerebral e servirem como avaliação adjuvante na constatação de diagnósticos diferenciais e melhorarem a acurácia do diagnóstico (MILLER, O'CALLAGHAN, 2015; MARTIN, 2011).

Para avaliar os NMS são realizados testes funcionais, não invasivos com bom custo benefício, normalmente fáceis de administrar que podem ser realizados na casa do doente ou até mesmo on line em alguns casos. A escala de sintomas não motores para doença de Parkinson (NMSS) é uma ferramenta validada e utilizada amplamente em diversos estudos clínicos (GARCIA, FERNANDEZ, 2013; KIM, 2009). Em Garcia e Fernandez (2013) é investigada a correlação direta entre a 
NMSS e o questionário de qualidade de vida para doentes de Parkinson (PDQ39), assim como em Bonnet (2012); modelos de regressão linear correlacionam o NMSS e a HRQoL mensurada no PDQ39 (MARTIN, 2011).

Diversas terapias são utilizadas para retardar a progressão da DP e melhorar a longevidade. Dentre elas a administração de drogas precursoras de dopamina é a opção clínica inicial mais comum e efetiva para os pacientes com DP, porém ocasionalmente podem gerar efeitos adversos como alucinações, insônia, náuseas e discinesia. A discinesia é um dos mais severos efeitos de quem recebe a medicação cronicamente, sendo dose dependente e atingindo mais de $50 \%$ dos pacientes em cinco anos de tratamento. Agentes antioxidantes podem ser uma escolha terapêutica potencial para DP. O suporte familiar, o serviço de saúde disponível e a comunicação são fatores que influenciam no tratamento e na melhora funcional dos doentes (YANG e col., 2011; LEONARDI, 2012; NAM KIM e col., 2013).

Terapias alternativas e/ou complementares como a fisioterapia, musicoterapia, psicologia e acupuntura cada dia mais se propagam no tratamento para alívio dos sintomas motores e não motores e na melhora da qualidade de vida. Cerca de $40 \%$ dos pacientes utilizam alguma forma de terapia complementar durante o curso da doença (NAM KIM e col., 2013; TOOSIZADEH e col., 2015; WANG e col., 2011; YEO e col., 2014; YANG e col., 2011).

\section{2 - Acupuntura}

A acupuntura é uma técnica terapêutica milenar da Medicina Tradicional Chinesa (MTC), uma das ciências mais antigas do mundo, e dados apontam achados de sua utilização desde 3000 anos antes de Cristo (ALLTREE, 1993; QIAOFENG e col., 2011; LIU e col., 2011; MUCHTADI e col., 2009).

Sua técnica tradicional consiste na aplicação de agulhas em pontos específicos do corpo, chamados acupontos, que transformam um estímulo mecânico em sinal elétrico gerando um potencial de ação, propagando o impulso nervoso que será conduzido até áreas corticais superiores e com isso proveram o alívio de sintomas (BRASIL, 2008; GOLDMAN, 1991; GRIGORY e col., 2006; HSIAO, TSAI, 
2008; MUCHTADI e col., 2009; SAIDAH e col., 2003; WHITE; CUMMINGS, 2009; YAMAMURA, 2001).

A acupuntura tem como seus principais objetivos terapêuticos a promoção da analgesia, a normalização neuromuscular, os efeitos anti-inflamatórios e neuroprotetores, a modulação imunológica, endócrina e psíquica (HELENE, DAVID, MARILYN, 2001; MUCHTADI e col., 2009; PARK e col., 2015).

Para a compreensão dos efeitos desencadeados pela acupuntura vale ressaltar a capacidade de modificação neuronal e sua atividade em resposta a diversos estímulos, que permite o sistema nervoso se adaptar e estabilizar. Alterações no sistema nervoso periférico e mudanças no ambiente neuronal geram sinais que são propagados por suas conexões, promovendo neuromodulação local e distante da origem da mudança, que podem estimular áreas cerebrais que são responsáveis por diferentes respostas orgânicas (HASTY e col., 2001; MUCHTADI e col., 2009).

A estimulação dos acupontos pode ocorrer por meio da inserção das agulhas, por estimulação manual (acupressão), elétrica (eletroacupuntura - EA) e laser, mas os mecanismos da ação de cada um desses estímulos ainda são controversos. Hipoteticamente a estimulação influencia no sistema imune, no aumento da circulação sanguínea, na pressão arterial, no ritmo e volume de sangue no coração, na secreção de suco gástrico, na produção de células brancas e vermelhas, no controle do estresse, na liberação hormonal e na liberação de fatores neurotróficos. (CHERKIN e col., 2008; HSIAO, TSAI, 2008; KIM, JEON, 2014; LINDE e col., 2001; LITSCHER, 2004; PARK e col., 2015;TAKIGUSHI e col., 2008).

A resposta sensorial à estimulação da acupuntura chama-se De Qi e pode ser descrita pelo paciente como um estado de entorpecimento, sensação de peso, distensão ou um "choque" no local de inserção e manipulação da agulha. O acupunturista consegue sentir um aumento da resistência da agulha. Acredita-se que a intensidade da resposta fisiológica gerada pela acupuntura esteja diretamente relacionada com a intensidade do De Qi (HSIAO, TSAI, 2008; HUI e col., 2011).

Uma hipótese atribuída pela intensidade do De Qi é o enrolamento do tecido conjuntivo, de fibras elásticas e colágenas suficiente para gerar um acoplamento mecânico entre a agulha e o tecido. A transdução desse sinal mecânico sinaliza uma 
resposta celular, com aparente espessamento tecidual subcutâneo. A observação pela microscopia eletrônica demonstrou que as fibras colágenas estavam mais alinhadas quando realizada a rotação das agulhas, sugerindo que o efeito é propagado pelo acoplamento da agulha com as fibras, transmitindo o sinal mecânico pela deformação da matriz extracelular e de células como os fibroblastos (HELENE; DAVID, MARILYN, 2001).

A acupuntura produz seus efeitos regulando o sistema nervoso central, em locais específicos que auxiliam a liberação de opióides, como as endorfinas, e células do sistema imunológico. Altera também a bioquímica cerebral atuando na liberação de neurotransmissores agindo assim na regulação de processos fisiológicos como a dor, fluxo sanguíneo e temperatura (COLVIN, FORBES, FALLON, 2006; GOLDMAN, 1991; HSIA, TSAI, 2008; MOFFET, 2006; SUÀREZ e col., 2004; SUÀREZ e col.,2005;WHITE, CUMMINGS, 2009; YAMAMURA, 2001).

Os mecanismos de ação da acupuntura ainda estão sendo investigados, mas pode ele ser dividido em ação local, segmentar e supra segmentar. Ao redor da agulha é possível observar uma série de reações inespecíficas como: a vasodilatação com aumento da temperatura local durante a estimulação; a liberação de fatores pró-inflamatórios; a estimulação de fibras nervosas aferentes de todos os tipos em especial as do tipo A Delta, A beta e tipo $\mathrm{C}$ e a liberação de endorfinas locais, que ocorre pela lesão tecidual e micro irritação até alguns dias depois da estimulação, o que pode justificar seu efeito durante 2-3 dias após o tratamento (CARLSSON, 2002; KAGITANI, STENER-VICTORIN, WU, 2010; UCHIDA, HOTTA, 2010).

As adesões focais formam uma ligação mecânica entre a matriz extracelular e o citoesqueleto intracelular pelas integrinas. O deslocamento da membrana celular é transduzido por uma ligação entre as integrinas e uma proteína, que pode sofrer alterações conformacionais e iniciar uma série de reações e alterações no citoesqueleto. Em microscopia Helene, David e Marilyn, (2001) observaram que os fibroblastos modificaram-se para uma forma fusiforme com aumento da coloração da actina e sua redistribuição, o que pode comprovar o rearranjo do citoesqueleto induzindo a contração celular e a síntese proteica. 
A deformação celular pode conduzir a liberação de fatores de crescimento, a ativação de fosforilação de quinases que levam a síntese de proteínas e regulação na expressão de fatores de transcrição gênica de colágeno. Podem influenciar na síntese e liberação as citocinas, substâncias vasoativas, enzimas degradativas e elementos da matriz. Tal liberação pode influenciar ainda no meio extracelular modulando o sinal de transdução. A manipulação durante a acupuntura pode causar modificação estrutural causando uma onda de deformação da matriz propagando assim seu efeito para longe do local de inserção primária da agulha ( HAN et al, 2017; HELENE, DAVID, MARILYN, 2001; HSIAO, TSAI, 2008; LI et al, 2016).

Outra importância da deformação da matriz extracelular na produção do estímulo mecânico é a estimulação de fibras nervosas, fibras musculares lisas e células endoteliais, levando a possível indução na produção de eNOS e nNOS. O aumento na sua produção leva ao aumento do fluxo sanguíneo com alterações na circulação local. A inserção da agulha parece ser o estímulo inicial para a produção difusa de NO, que se propaga pela rede vascular alterando todo o sistema; a força dessas alterações e a produção de NO estão relacionadas com a frequência em que o estímulo acontece (HSIAO, TSAI, 2008).

Quanto à ação segmentar, a teoria da comporta de Melzac e Wall (1965) tornou-se a explicação mais racional, e a inibição pode ocorrer no momento ou em um curto período após a estimulação. Mas esse mecanismo explica somente o alivio da dor momentâneo e não sua permanência por dias e horas (ALLTREE, 1993; CARLSSON, 2002; MUCHTADI e col., 2009).

A liberação de endorfinas espinhais e supra espinhais também tem sido proposta, assim como a ativação do controle inibitório descendente através de vias bulboespinhais. O envolvimento de neurotransmissores como a serotonina, noradrenalina, diferentes endorfinas e hormônios como o ACTH e a cortisona tem sido investigado. Outra candidata a responsável pelos efeitos anti stress naturais causados pela acupuntura é a ocitocina (CARLSSON, 2002; KAGITANI.STENERVICTORIN. WU, 2010).

As vias descendentes inibitórias da dor na medula espinhal têm seus neurônios de origem no Núcleo Magno da Rafe (NMR) e usam serotonina como mediador. Os 
sistemas de endorfinas e seus receptores opióides também estão relacionados com a analgesia produzida pela estimulação da acupuntura. Os opioides endógenos mais comuns são beta-endorfinas, encefalinas e dinorfinas. Esse sistema inibitório pode permanecer ativo por aproximadamente oito horas (CARLSSON, 2002; KAGITANI,STENER-VICTORIN, WU, 2010).

Outros dois mecanismos estudados de ação central são: a ativação do eixo hipotálamo-hipófise-adrenal com o aumento sanguíneo de beta-endorfinas, ACTH e cortisol; e o fenômeno de potenciação de longa duração (LTP) e o potencial depressor de longo prazo (LTD) no SNC (CARLSSON, 2002).

\subsection{Acupuntura na DP baseada em evidências}

Alguns estudos correlacionando a utilização da acupuntura como tratamento complementar na DP nos últimos anos tem se apresentado promissores. Segundo Wang e col., 2011, em seu experimento com modelos animais de DP, a utilização da EA em $100 \mathrm{~Hz}$ nos pontos PC6 e E36 podem ter um efeito neuroprotetor nos neurônios dopaminérgicos da SNc por reverter a elevação dos radicais livres e inibir a elevação dos oxidantes no núcleo estriado, tendo assim por consequência a melhora das desordens motoras em seus animais.

Outro estudo com modelo animal investigou os efeitos da acupuntura no ponto PC7 e concluíram que possivelmente essa terapia atenue os danos neuronais causados pela DP (YANG e col., 2011).

Nam Kim em 2013, em uma pesquisa com modelo animal de DP, investigou se a acupuntura no ponto VB34 combinado com a terapia com L-Dopa poderia minimizar as limitações da terapia farmacológica sozinha; e se essa combinação promovia a melhora da função motora, aliviando a discinesia induzida pela droga. Como resultado demostraram que o efeito da L-Dopa é significantemente aumentado quando combinado com acupuntura, e que a combinação de acupuntura com doses mais baixas da droga potencializam as funções motoras sem a ocorrência de seus efeitos adversos. O que é interessante, pois neste caso os 
autores investigaram diversas doses e observaram que com a metade da dosagem da droga eles obtinham os mesmos benefícios quando combinando terapias.

Estudo realizado por Park e col. (2015) em roedores investigaram a possível via responsável pelo efeito neuroprotetor da acupuntura em modelos de DP utilizando o ponto VB34 (localizado na depressão anterior e distal da cabeça da fíbula), e demonstraram que a acupuntura leva à expressão diferencial de algumas proteínas e que essas poderiam levar a sobrevida neuronal, sugerindo que o efeito neuroprotetor com melhora das funções motoras ocorra por uma sinalização via p53, que é conhecida pelo seu papel fundamental no entendimento do dano ao DNA e da resposta celular a vários agentes estressores que afetam a integridade neuronal, onde sua inibição mostrou-se ser benéfica nos casos de danos neuronais. Outro ensaio realizado em modelos animais utilizando a acupuntura e a EA nos pontos VB34, BP6 e E36 mostrou-se eficiente no aumento da expressão dos transportadores pré-sinápticos de dopamina no estriado e na substância negra além de melhora na expressão dos receptores D1 e preveniu o aumento na expressão de receptores $\mathrm{D} 2$, sugerindo outro mecanismo de atuação da acupuntura na sobrevida neuronal e na melhora dos sintomas da DP (RUI e col., 2013).

Zeng e col., em 2014, em modelo animal, sugeriram que a acupuntura nos pontos VB34 e R3 poderia atenuar o estresse oxidativo e inibir a morte dos neurônios da SNc pela inibição da produção de $\mathrm{H}_{2} \mathrm{O} 2$, diminuição nos níveis de ferro e ferritina e restauração da ativação de proteínas sinalizadoras de neuroproteção. Como resultado, teríamos a melhora na função motora com a proteção neuronal dopaminérgica. Yeo, Choi, Hong e Lim (2013) investigaram as alterações nos perfis de expressão gênica de regiões talâmicas em modelo animal de DP e sua relação com o efeito inibitório da acupuntura em tais regiões. Seus resultados sugeriram que a estimulação com acupuntura suprimiu e diminuiu as alterações patológicas induzidas pela intoxicação com MPTP no estriado e substância negra quando comparados com o placebo (colocação de agulhas em regiões onde não são pontos de acupuntura) e que oito genes em comum são afetados pelo MPTP e também pela acupuntura, podendo estes serem os responsáveis pelo efeito protetor da acupuntura no tálamo. Yeo e col. (2015) também encontraram em seus resultados doze genes que são alterados pela intoxicação por MPTP e pela acupuntura na 
substância negra e sugeriram que a via existente entre substancia negra e tálamo possa ser a responsável pelo efeito neuroprotetor desempenhado pela acupuntura.

Deng e col. em 2015 realizaram um estudo com o objetivo de investigar as bases neuroquímicas responsáveis pelos efeitos terapêuticos da EA com intensidade de $100 \mathrm{~Hz}$ nos pontos E36 e BP6,utilizando modelos animais. Como resultado obtiveram aumento da sobrevida dos animais por diminuir a expressão não neuronal de a-syn inibindo as respostas inflamatórias e assim protegendo os neurônios dopaminérgicos. Portanto seus resultados sugerem que a EA pode inibir processos degenerativos em múltiplos níveis sendo uma ferramenta em potencial para o tratamento da DP.

Em 2014 um estudo realizado por Wattanathorn e Sutalangka utilizou a aplicação de laser no ponto C7 em modelos animais e observou que os mesmos melhoram seus testes de memória espacial e memória retentora, sugerindo que a acupuntura atenuou os distúrbios nos neurotransmissores dopamina e acetilcolina no giro denteado e hipocampo.

Outro trabalho investigou o impacto da EA com $100 \mathrm{~Hz}$ nas atividades espontâneas locomotoras em animais modelos de DP e demonstraram que houve melhora no controle da discinesia que os animais apresentavam e quando mensurados os níveis de dopamina e seus metabólitos estes foram maiores no grupo submetido ao tratamento do que no grupo sem tratamento, sugerindo assim que a acupuntura poderia ter efeitos extensivos neuroprotetores e reguladores na DP. (WANG e col., 2013). Sun e col., 2012, sugeriram com seus resultados que a EA com frequência de $100 \mathrm{~Hz}$ realizada nos pontos VG24 e VG20 previne a perda de neurônios dopaminérgicos, mas não altera o nível de dopamina no estriado e sim os níveis de glutamato e acetilcolina nessas estruturas.

Kim e col. em 2011 compararam com modelos animais os efeitos da acupuntura no ponto VB34, na função motora e na sobrevivência dos neurônios dopaminérgicos, mensurando alterações nas expressões de DARPP-32 e FosB, dentre outros marcadores. E pode concluir que houve um aumento da liberação de dopamina após o tratamento e isso permitia um aumento do neurotransmissor na fenda sináptica que por sua vez teria um papel essencial na melhora da função motora. 
Em 2016, Yu e col. avaliaram em modelos animais a aplicação de EA com intensidade de $100 \mathrm{~Hz}$ nos pontos E36 e BP6 e seus resultados sugeriram que o tratamento crônico com EA atenuou as deficiências motoras e conferiu um efeito neuroprotetor nos animais, mas o mais importante relatado pelos autores foi a demonstração de que os efeitos de melhora motora permaneceram por duas a quatro semanas após o término do estímulo e a melhora nos níveis disponíveis de dopamina no estriado foram também mantidos por duas semanas após o término do tratamento

Em um estudo feito com pacientes diagnosticados com DP idiopática, Yeo e col. (2014) utilizaram a estimulação do ponto de acupuntura VB34 para verificar, através de fMRI, se ocorria ativação das principais áreas acometidas pela doença e se existia diferença na atividade cerebral de pacientes com DP e indivíduos saudáveis. Seu estudo demonstrou que a acupuntura promoveu a ativação de locais diferentes quando comparados sujeitos saudáveis em relação aos com DP e que as regiões do córtex pré-frontal e giro pré-central são ativadas e correlacionadas à melhora dos sintomas da doença.

Uma revisão bibliográfica realizada por Kim e Jeon em 2014 avaliou a eficácia da acupuntura na DP idiopática em ensaios clínicos, e observou-se melhora na qualidade de vida, nos sintomas depressivos e na escala da UPDRS parte motora após a utilização da acupuntura quando comparada ao grupo placebo. O ponto mais utilizado nos ensaios clínicos foi VB34, seguido por E36. Nesta revisão os autores também descrevem os principais problemas na área que são a falta de follow-up, o pequeno número de amostras e discrepância nos pontos utilizados.

Em uma revisão bibliográfica Wang, Z. e col., 2013, descreveram alguns estudos que utilizavam exames de imagens avaliando a possível ação da acupuntura no tratamento da DP. Com PETscan foi possível notar um aumento no metabolismo da glicose cortical em diversas regiões no lado menos afetado e utilizando SPECT notou-se um aumento no fluxo sanguíneo no hemisfério mais afetado após o tratamento, sugerindo efeitos positivos da utilização da acupuntura.

Um estudo realizado em 2015 por Toosizadeh e col. avaliou o equilíbrio postural após a realização de EA em pacientes com DP idiopática e os resultados obtidos foram favoráveis a melhora com EA em relação a placebos utilizando os 
pontos VG20, VG14, E36, IG4, VB34, BP6, R3 F3 e B40. Interessante que os dados foram observados também no período "off" medicação de doze horas.

\subsection{Justificativa}

A escassez de dados relevantes sobre os sintomas não motores e a qualidade de vida na doença de Parkinson, seria interessante um tratamento complementar que pudesse melhorar os distúrbios motores e não motores desses pacientes, sem aumentar a dosagem das medicações, suavizando assim os efeitos colaterais e com isso melhorando a qualidade de vida. Neste projeto foi elaborado um protocolo com os pontos mais utilizados e pesquisados na área, que abrangem o tratamento como todo (sintomas motores e não motores) segundo a descrição pela medicina chinesa da indicação de cada um dos pontos escolhidos. Utilizando de ferramentas validadas e confiáveis para sua mensuração. 


\section{2 . Objetivo}

\subsection{Objetivo Geral}

Verificar o efeito do tratamento da acupuntura nos sintomas motores e não motores dos pacientes com doença de Parkinson.

\subsection{Objetivo específico}

Observar se ocorre alguma alteração nos questionários antes e após o tratamento.

Observar se há alterações na escala analógica visual de dor antes e após o tratamento.

Verificar se há alguma relação entre melhora motora e qualidade de vida e melhora dos sintomas não motores e qualidade de vida. 


\section{Metodologia}

\subsection{0 experimento}

A pesquisa foi realizada no Hospital das Clínicas (HC- SP) da Universidade de São Paulo (USP), no Instituto de Psiquiatria, sob a supervisão de neurologistas clínicos e cirúrgicos. O experimento consistiu em um tratamento de cinco sessões de acupuntura que foram realizadas uma vez por semana, com duração de aproximadamente 30 minutos de terapia total (considerando tempo para recepcionar o voluntário, mensurar sinais vitais, posicionar, inserir as agulhas, retirar as agulhas e liberar o voluntário). Os pacientes foram aleatoriamente selecionados do ambulatório de neurocirurgia. Os critérios para inclusão foram aqueles com idade entre 40 e 70 anos, com grau de instrução o suficiente para ler os questionários aplicados, com diagnóstico médico de DP idiopática, sem cirurgias neurológicas prévias, que tivessem disponibilidade de comparecer uma vez por semana ao ambulatório durante um período de onze semanas consecutivas e que não apresentassem nenhuma outra doença neurológica.

Inicialmente os pacientes assinaram um termo de consentimento livre e esclarecido (TCLE) (anexo 1), no qual estavam explicados os objetivos da pesquisa e o procedimento experimental adotado, ficando explícito que a participação na pesquisa era totalmente voluntária e que não haveria qualquer impedimento para uma desistência.

Após isso foram avaliadas a frequência cardíaca $(F C)$ e pressão arterial (PA), antes e após todas as sessões. Em seguida foram aplicados alguns questionários:

1. Questionário com dados pessoais e com dados sobre medicações e tratamentos utilizados (anexo 2);

2. MDS-UPDRS (Unifield Parkinson Disease Rating Scale): dividido em quatro domínios, parte I avaliação de NMS, parte || experiências motoras, parte || exame motor e parte IV complicações motoras (KOVÁCS, 2016) (anexo 3);

3. Escala de Hoehn e Yahr: escala que avalia a incapacidade dos pacientes sendo capaz de indicar o estado geral do mesmo. Consiste em sete estágios de classificação que abrange os sinais e sintomas apresentados. Os pacientes 
classificados de 1 a 3 apresentam incapacidade leve a moderada, nos estágios 4 e 5 apresentam incapacidade grave (MELLO, BOTELHO, 2010; TIAGO, ALMEIDA, SANTOS, VERONEZI, 2010) (anexo 4);

4. Questionário de HRQoL para Doença de Parkinson (PDQ39): questionário desenvolvido pelo departamento de Saúde Pública da Universidade de Oxford, na Inglaterra, validado no Brasil, sensível a alterações que interessam os pacientes. Composto por oito domínios (mobilidade, atividade de vida diária, bem-estar emocional, estigma, suporte social, cognição, comunicação e desconforto corporal) que variam de 0 a 100 , sendo que quanto maior 0 escore pior a qualidade de vida. (KOVÁCS, 2016; MARTIN, 2011; SOH, MORRIS, McGINLEY,2011; MELLO, BOTELHO, 2010; TIAGO, ALMEIDA, SANTOS, VERONEZI, 2010) (anexo 5);

5. Escalas de sintomas não motores para Doença de Parkinson (NMSS), que consiste em 30 questões dividido em nove domínios (sono, sintomas cardiovasculares, cognição, humor, alucinações, sintomas gastrointestinais, sintomas urinários, sintomas sexuais e problemas diversos) de avaliação da frequência e severidade dos NMS (KOVÁCS, 2016; KIM e col., 2009; KIM e col., 2013; MELLO, BOTELHO, 2010) (anexo 6);

6. Mini mental (MMSE) (anexo 7);

7. Escala visual analógica de dor (anexo 8).

Os sete itens acima foram aplicados antes do início do tratamento com ACP, após a quinta sessão. Para cada momento de avaliação foi pedido que o paciente ficasse sem as mediações anti-parkinsonianas por no mínimo doze horas (12h) (GARCIA, FERNANDEZ, 2013) para garantir um período off medicação para a aplicação da UPDRS-parte III. Após a avaliação era solicitado ao paciente que o mesmo tomasse sua medicação na dose de costume. Após no mínimo quarenta minutos (período médio para ação da medicação) foi realizada uma segunda avaliação da UPDRS- parte III mas agora em um momento chamado on. Durante esse intervalo eram realizados os demais questionários e escalas. Todas as respostas eram realizadas pelo paciente sem a intervenção do avaliador 
O tratamento consistiu na introdução das agulhas, de aço inoxidável e descartáveis, da marca Dong Bang de $30 \mathrm{~mm}$ por $25 \mathrm{~mm}$, nos pontos préselecionados, a partir de uma revisão bibliográfica:

$\checkmark$ IG4 bilateralmente, localizado na metade do segundo metacarpo, entre o primeiro e o segundo ossos metacarpais ou sobre a saliência muscular quando se faz a abdução do polegar (MARTINS. GARCIA, 2003) (figura 2);

$\checkmark$ F3 bilateralmente, localizado no dorso do pé, na depressão interóssea distal localizada entre o primeiro e o segundo metatarsos e a 2cun acima da prega interdigital (MARTINS, GARCIA, 2003) (figura 3);

$\checkmark$ VB34 bilateralmente, localizado no terço superior da face lateral da perna na depressão muscular localizada anterior e inferior a cabeça da fíbula (MARTINS, GARCIA, 2003) (figura 4);

$\checkmark$ BP6 bilateralmente, localizado na face medial da perna, 3cun acima da extremidade do maléolo medial, na fossa posterior à margem medial da tíbia (MARTINS. GARCIA, 2003) (figura 5);

$\checkmark$ VB20 bilateralmente, localizado na região lateral e posterior do pescoço na depressão entre a extremidade superior do músculo esternocleidomastoideo e a margem superior do músculo trapézio, ou na depressão óssea localizada entre a tuberosidade occipital externa e o processo mastóide (MARTINS. GARCIA, 2003) (figura 6);

$\checkmark$ VG20 localizado na linha média, no topo da cabeça, na intersecção da linha mediana do corpo com a linha que parte do eixo vertical das orelhas (MARTINS, GARCIA, 2003) (figura 7).

As agulhas permaneceram por vinte minutos, foram retiradas e após a mensuração da FC a PA o paciente foi liberado. Foram monitorados durante o experimento as medicações e dosagens utilizadas e os tratamentos realizados, sendo orientado para que qualquer alteração o paciente avisasse o experimentador. Quanto aos horários das sessões, foram mantidos os mesmos desde o primeiro atendimento, para não interferir no momento de ação das medicações 


\subsection{Análise estatística}

Inicialmente análises descritivas foram realizadas com o objetivo de explorar o comportamento dos dados. Foram construídos para cada variável de interesse gráficos de comportamento dos pacientes antes e após a quinta sessão de intervenção, e tabelas de médias e desvio padrão. Transformações; raiz quadrada ou arco seno da raiz quadrada da proporção; foram empregadas para medidas discreta ou porcentagem. $O$ efeito das cinco sessões de intervenção foi analisado estatisticamente empregando-se teste t-Student pareado ou Wilcoxon de acordo com as medidas de distribuição; achatamento e simetria. As variáveis obtidas do questionário UPDRS parte III foram analisadas empregando-se análise de variância (ANOVA) para medidas repetidas nos períodos com e sem medicação e antes e após a quinta sessão de intervenção. O nível de significância estatístico estabelecido foi $p<0,05$.

\subsection{Aspectos éticos e legais}

O procedimento utilizado na pesquisa não resultou em qualquer prejuízo para os voluntários, possibilitando por outro lado a eles usufruir algum benefício. Os únicos inconvenientes do procedimento que poderiam sem relatados pelos pacientes seriam algum desconforto no local de inserção das agulhas, aparecimento de vermelhidão e/ou pequeno sangramento local e sudorese por ativação do sistema nervoso simpático. Destacamos que qualquer intercorrência imprevista, caso ocorresse, seria resolvida pelo médico que acompanhou a pesquisa. A médio prazo o procedimento não apresentou quaisquer inconvenientes para os voluntários. Como benefício de curto prazo do procedimento, os voluntários apresentaram sensação de relaxamento e bem-estar. 


\section{Resultados}

\section{1 - Descrição da amostra}

Foram selecionados 30 prontuários de pacientes aleatoriamente durante 3 dias, desses, foram excluídos 15 prontuários por diversos motivos como faltas constantes em consultas agendadas, existência prévia de procedimento cirúrgico neurológico e apresentarem outros diagnósticos de patologias neurológicas. Dos 15 pacientes selecionados somente realizaram o experimento sete pacientes. Os outros oito pacientes foram excluídos da pesquisa, pois não apresentavam disponibilidade de comparecer na instituição.

A amostra, portanto, foi composta por sete voluntários, todos do sexo masculino, com idade média de 64 anos, variando de 56 anos a 75 anos. O tempo médio de diagnóstico da doença foi de 8,8 anos (variando de 3 anos a 13 anos). A escala de Hoehn\&Yahr média foi de 2,5 com variação entre 2 e 3, portanto em estágio leve a moderado da doença. A tabela 1 descreve em detalhes a amostra. 


\begin{tabular}{|c|c|c|c|c|c|c|c|}
\hline & P1 & P2 & P3 & P4 & P5 & P6 & P7 \\
\hline Idade & 64 & 56 & 56 & 66 & 64 & 75 & 70 \\
\hline Escolaridade & $\begin{array}{c}\text { EM } \\
\text { completo }\end{array}$ & Técnico & $\begin{array}{c}\mathrm{EM} \\
\text { completo }\end{array}$ & 5 série & 4 série & $\begin{array}{c}\text { superior } \\
\text { incompleto }\end{array}$ & 3 série \\
\hline Tempo da doença & 12 & 13 & 3 & 9 & 8 & 12 & 5 \\
\hline Comorbidade & HAS & & & & & & DM \\
\hline Hoen Yard & 2 & 2.5 & 2 & 2.5 & 3 & 3 & 2 \\
\hline Outras terapias & Psico & $\begin{array}{l}\text { Fono e } \\
\text { fisio }\end{array}$ & Hidro & & $\begin{array}{l}\text { Fono e } \\
\text { Psico }\end{array}$ & & \\
\hline \multicolumn{8}{|l|}{ Medicações: } \\
\hline Prolopa & $\begin{array}{c}8 x / \text { dia } 1 \\
1 / 4\end{array}$ & $\begin{array}{c}6 x / \text { dia } \\
3 / 4\end{array}$ & 4x/dia 1 & $\begin{array}{c}4 x / \text { dia } \\
1 / 2\end{array}$ & $\begin{array}{c}6 x / \text { dia } \\
1 / 2\end{array}$ & $5 x /$ dia 1 & $4 x /$ dia 1 \\
\hline Itacapone & 3x/dia 1 & & & & & & $4 x /$ dia 1 \\
\hline Amantadina & $2 x /$ dia 1 & $3 x /$ dia 1 & & & $3 x /$ dia 1 & & \\
\hline Pramipexol & $\begin{array}{c}3 x / \text { dia } \\
1 / 2\end{array}$ & $3 x /$ dia 1 & $3 x /$ dia 2 & $3 x /$ dia 3 & $3 x /$ dia 1 & & $4 x /$ dia 1 \\
\hline Fenasterida & 1x/dia 1 & & & & & & \\
\hline Gabapentina & & $\begin{array}{c}1 x / \text { noite } \\
1\end{array}$ & & & & & \\
\hline HBS & & $\begin{array}{c}1 x / \text { noite } \\
1\end{array}$ & & $\begin{array}{c}1 x / \text { noite } \\
1\end{array}$ & & $1 x /$ noite & \\
\hline Selegilina & & & 2x/dia 1 & & & & \\
\hline Amitriptilina & & & & $\begin{array}{c}1 x / \text { noite } \\
1\end{array}$ & $\begin{array}{c}1 x / \text { noite } \\
1\end{array}$ & & \\
\hline Tramadol & & & & & $3 x /$ dia 1 & & \\
\hline Dipirona & & & & & $\begin{array}{c}4 x / \text { dia } \\
40 \text { gotas }\end{array}$ & & \\
\hline Losartana & & & & & & 1x/dia & \\
\hline Prolopa DR & & & & & & & $1 x /$ noite \\
\hline
\end{tabular}

Tabela 1: Descrição da amostra: pacientes P1 a P7, HAS (hipertensão arterial sistêmica), DM (diabetes mielitus), Psico (psicologia), Fono (fonoaudiologia) e Fisio (fisioterapia). Nas medicações estão a quantidade de doses e o número de comprimidos/gotas. 


\section{2- Dados coletados}

Para os valores obtidos na escala analógica visual de dor (Tabela 2, Gráficos 1 e 2), o teste t-Student para dados pareados detectou diferença significante entre os dois momentos $p=0,002$, a acupuntura altera o nível de dor com a realização de cinco sessões (S5) de acupuntura quando comparado ao momento inicial (S0).

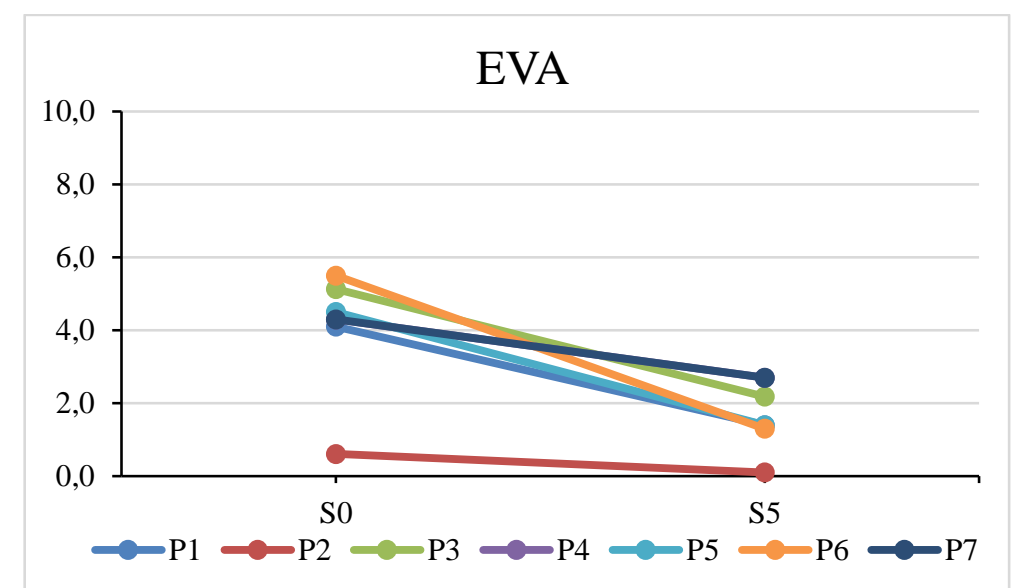

Gráfico1: Resultados obtidos EVA (antes e após a quinta sessão)

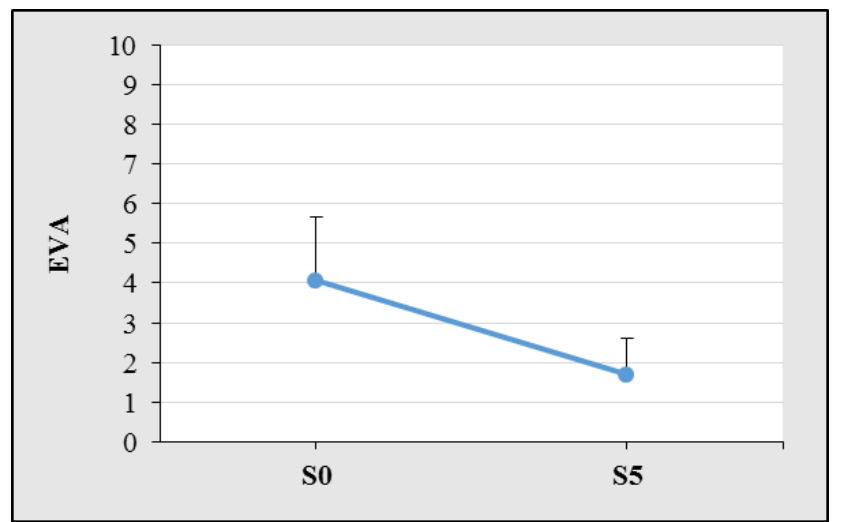

Gráfico 2: Resultados obtidos após estatística (EVA): Média e DP dos valores de EVA antes (SO) e após cinco sessões de acupuntura (S5). Teste t-Student pareado, $S 5 \neq S 0, p=0,002$.

\begin{tabular}{cccc}
\hline Sessão & Média & DP & N \\
\hline S0 & 4,05 & 1,60 & 7 \\
S5 & 1,69 & 0,934 & 7
\end{tabular}

Tabela 2: Descrição estatística (EVA): Média, desvio-padrão e tamanho da amostra dos valores de EVA antes (S0) e após cinco sessões de acupuntura (S5). 
Quando analisados com anova os resultados encontrados na avaliação da UPDRS parte III (exame motor) (gráficos 3 e 4) nos dois momentos on e off medicação detectou efeito significante das cinco sessões de acupuntura, independente da medicação, $p=0,030$ (gráficos 5 e tabela 3) Foi detectado também efeito significativo da medicação independente de ter realizado ou não as 5 sessões de acupuntura, $p<0,001$.

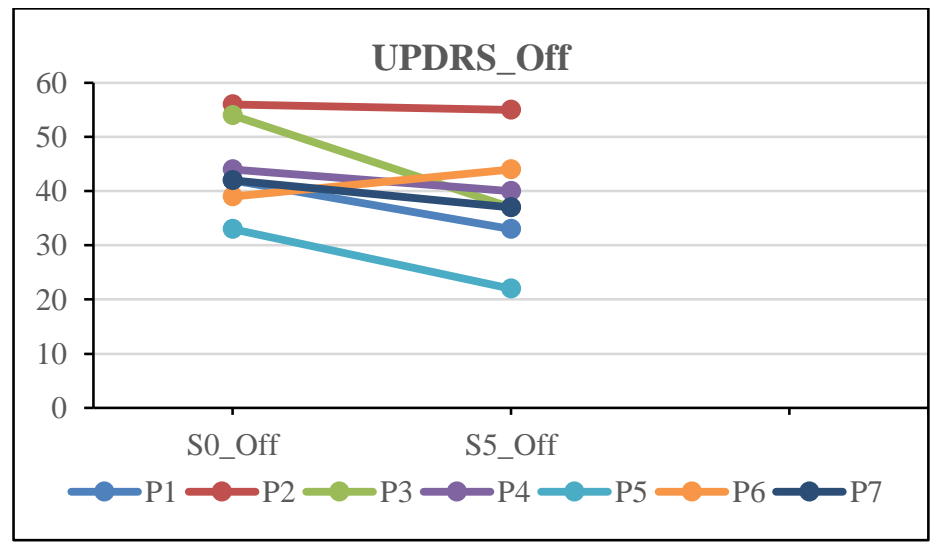

Gráfico 3: Resultados obtidos UPDRS parte III (antes e depois): momento off medicação

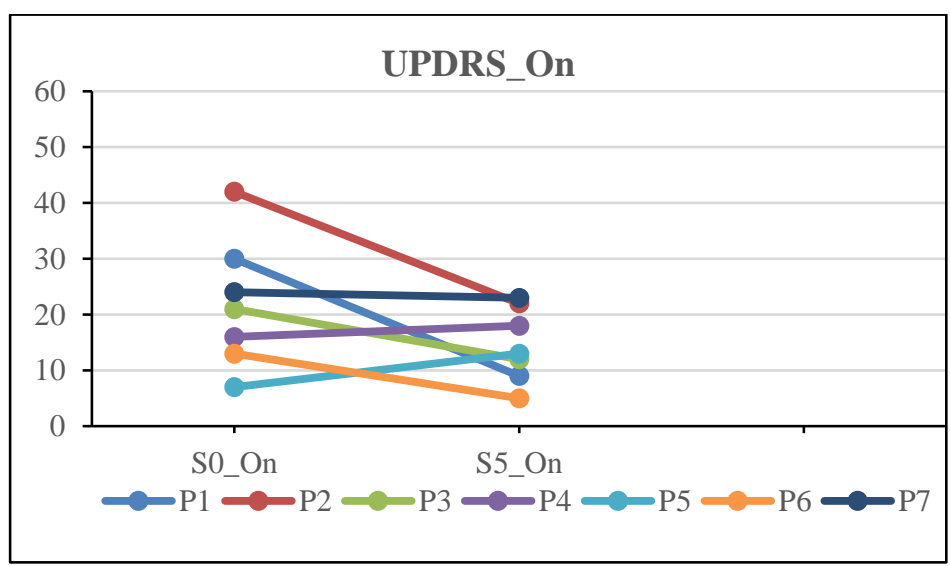

Gráfico 4: Resultados obtidos UPDRS parte III (antes e depois): momento on medicação 


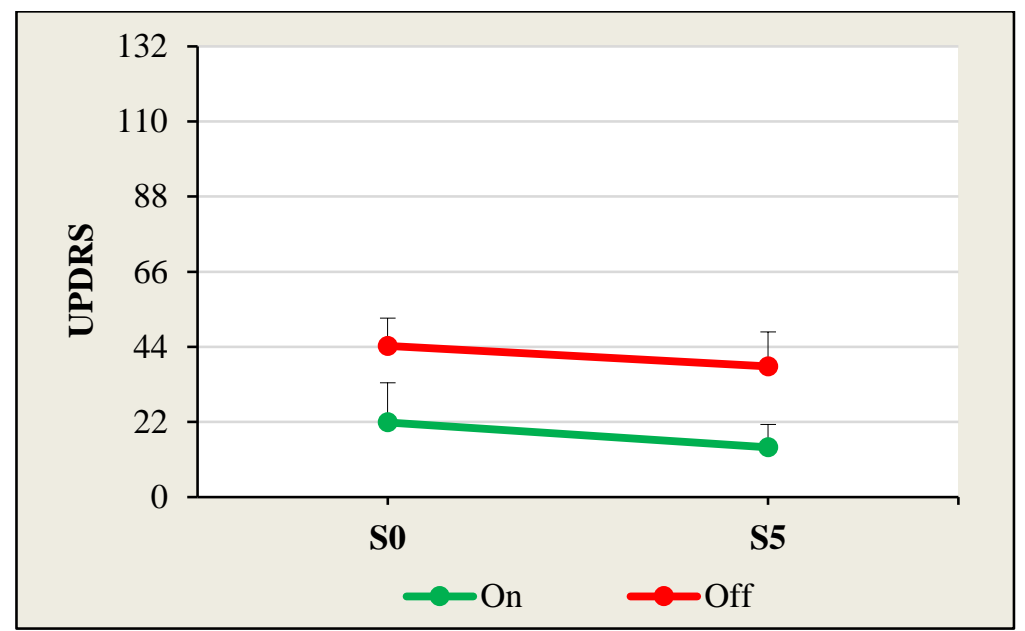

Gráfico 5: : Resultados obtidos após estatística (UPDRS - parte III) Média e DP dos valores de UPDRS antes (S0) e após cinco sessões de acupuntura (S5), sem ("off") ou com ("on") a medicação. ANOVA: Sessão*Medicação, $p=0,588$; Sessão, $p=0,030$ ( $S 5 \neq S 0$, independente da Medicação); Medicação, $p<0,001$ (OnfOff, independente da Sessão).

\begin{tabular}{cccc}
\hline Sessão_Medicação & Média & DP & N \\
\hline S0_Off & 44,29 & 8,14 & 7 \\
S0_On & 21,86 & 11,63 & 7 \\
S5_Off & 38,29 & 10,09 & 7 \\
S5_On & 14,57 & 6,70 & 7 \\
\hline
\end{tabular}

Tabela 3: Descrição estatística (UPDRS - parte III): Média, desvio-padrão e tamanho da amostra dos valores de UPDRS sem ("off") e com ("on") medicação e antes (SO) e após cinco sessões de acupuntura (S5).

Os dados encontrados no questionário Mini mental (gráfico 6) foram analisados empregando-se o teste t-Student e não foi detectada diferença significante entre as sessões $(p=0,057)$ (gráfico 7$)$. A descrição estatística dos dados está descrita na tabela 4. 


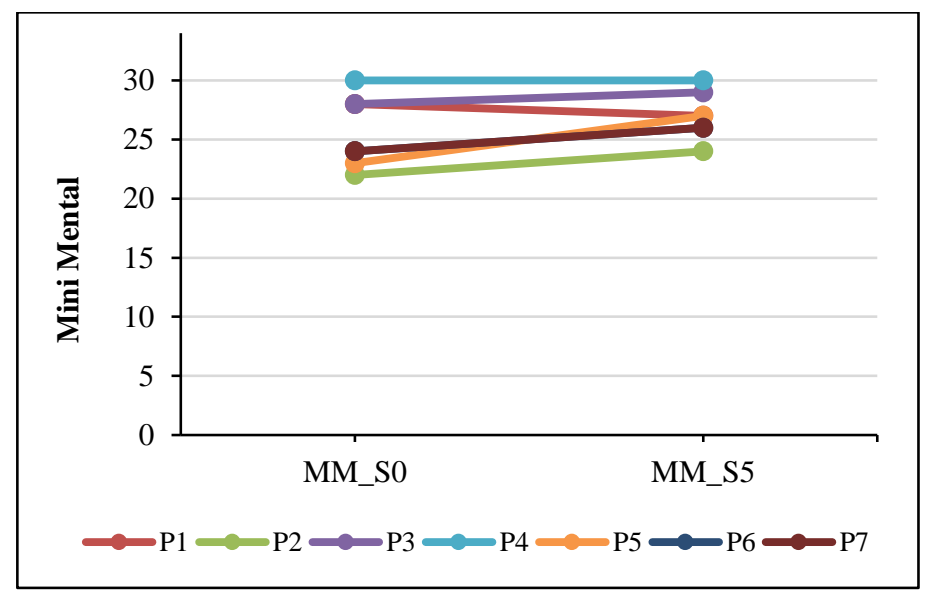

Gráfico 6: Resultados obtidos mini mental (antes e depois)

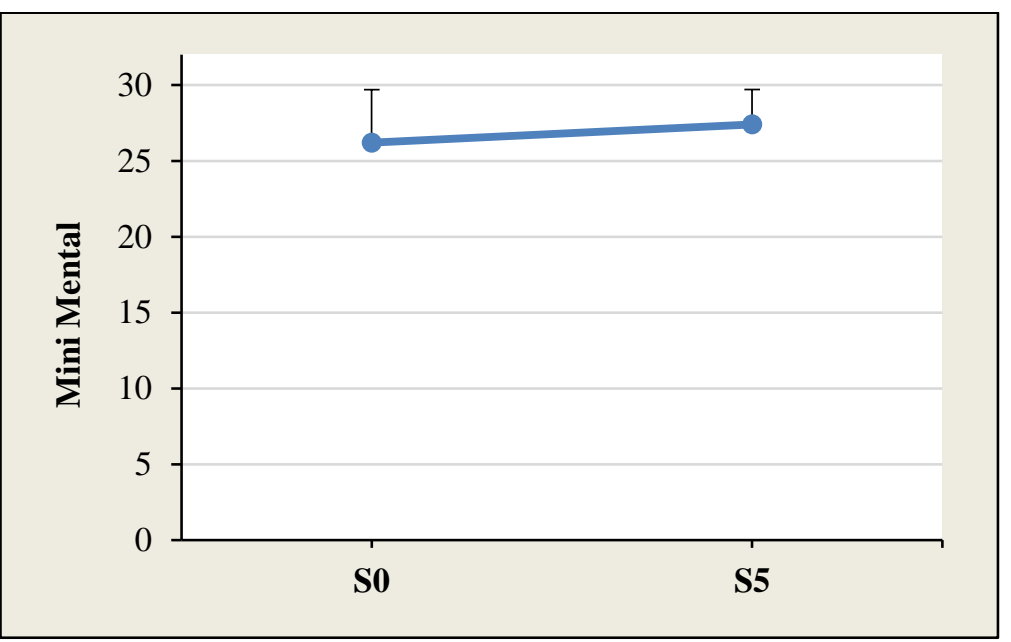

Gráfico 7: Resultados obtidos após estatística (mini mental): Média e DP dos valores do questionário Mini Mental antes (S0) e após cinco sessões de acupuntura (S5). Teste tStudent pareado, $p=0,057$.

\begin{tabular}{cccc}
\hline Sessão & Média & Desvio padrão & N \\
\hline S0 & 25,6 & 3,0 & 7 \\
S5 & 27,0 & 2,0 & 7
\end{tabular}

Tabela 4: Descrição estatística (mini mental): Média, desvio-padrão e tamanho da amostra dos valores do questionário Mini Mental antes (S0) e após cinco sessões de acupuntura (S5).

Para a análise do questionário de sintomas não motores primeiramente foi realizada a análise de cada um dos domínios: cardiovascular; sono e fadiga; humor e cognição; percepção e alucinação; atenção e memória; gastrointestinal; urinário; função sexual; miscelânea; e posteriormente do seu valor total. $O$ efeito das cinco 
sessões de acupuntura foi avaliado empregando-se teste t-Student para dados pareados ou Wilcoxon.

\begin{tabular}{ccccc}
\hline Domínio & Sessão & Média & DP & N \\
\hline \multirow{2}{*}{ Cardiovascular } & S0 & 3,29 & 4,07 & 7 \\
& S5 & 1,00 & 1,29 & 7 \\
\hline \multirow{2}{*}{ Sono e Fadiga } & S0 & 13,43 & 9,62 & 7 \\
& S5 & 5,43 & 6,16 & 7 \\
\hline Humor e & S0 & 11,86 & 9,58 & 7 \\
Cognição & S5 & 7,29 & 9,79 & 7 \\
\hline Percepção e & S0 & 1,71 & 4,54 & 7 \\
Alucinação & S5 & 0,00 & 0,00 & 7 \\
\hline Atenção e & S0 & 3,29 & 5,79 & 7 \\
Memória & S5 & 1,43 & 1,81 & 7 \\
\hline \multirow{2}{*}{ Gastrointestinal } & S0 & 8,71 & 6,90 & 7 \\
& S5 & 3,14 & 6,62 & 7 \\
\hline \multirow{2}{*}{ Urinário } & S0 & 9,86 & 11,04 & 7 \\
& S5 & 7,86 & 10,14 & 7 \\
\hline \multirow{2}{*}{ Função Sexual } & S0 & 5,14 & 9,44 & 7 \\
\hline \multirow{2}{*}{ Miscelânea } & S5 & 2,14 & 4,49 & 7 \\
\hline \multirow{2}{*}{ Total } & S0 & 3,86 & 4,85 & 7 \\
& S5 & 1,14 & 1,07 & 7 \\
\hline S0 & 61,14 & 26,63 & 7 \\
& S5 & 29,43 & 21,72 & 7
\end{tabular}

Tabela 5: Descrição estatística NMSS: Média, desvio-padrão e tamanho da amostra dos domínios do questionário de sintomas não-motores: cardiovascular; sono e fadiga; humor e cognição; percepção e alucinação; atenção e memória; gastrointestinal; urinário; função sexual; miscelânea e total, antes (S0) e após cinco sessões de acupuntura (S5).

No domínio cardiovascular (Tabela 5 e gráficos 8 e 9), não foi detectado efeito significante das cinco sessões de acupuntura, $p=0,171$. 


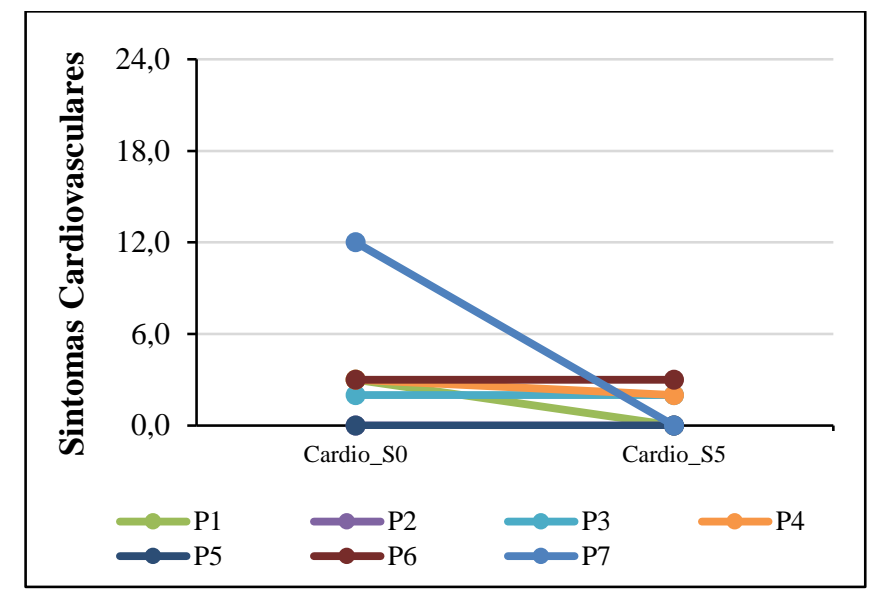

Gráfico 8: Resultados obtidos NMSS -domínio cardiovascular (antes e depois)

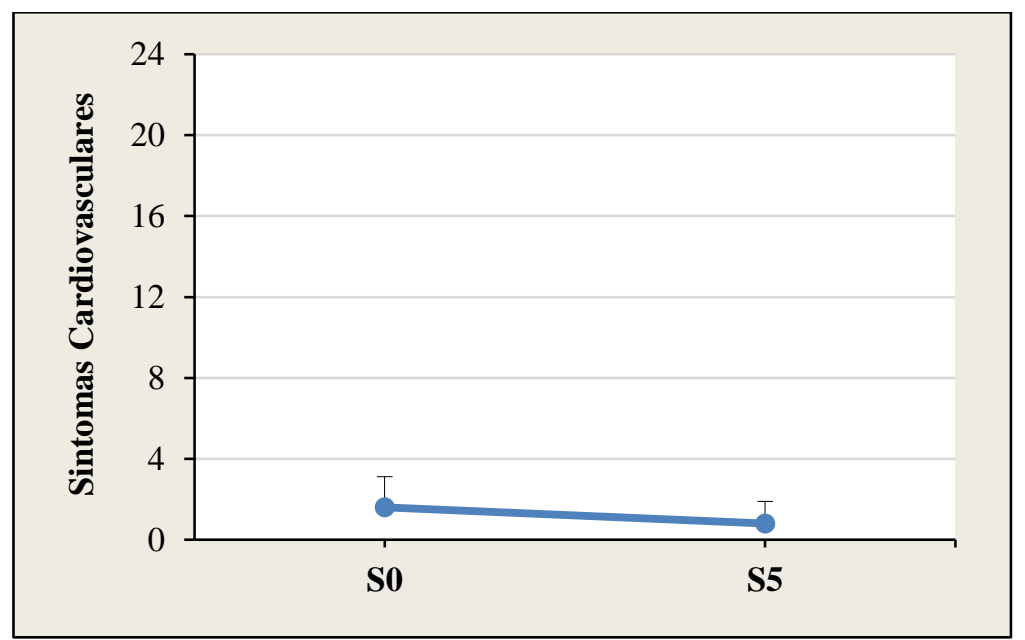

Gráfico 9: Resultados obtidos após estatística (NMSS - domínio cardiovascularl): Média e DP dos valores, antes (S0) e após cinco sessões de acupuntura (S5). Teste t-Student pareado, $p=0,171$.

No domínio sono e fadiga (Tabela 5 e gráficos 10 e 11), não foi detectado efeito significante das cinco sessões de acupuntura, $p=0,072$. 


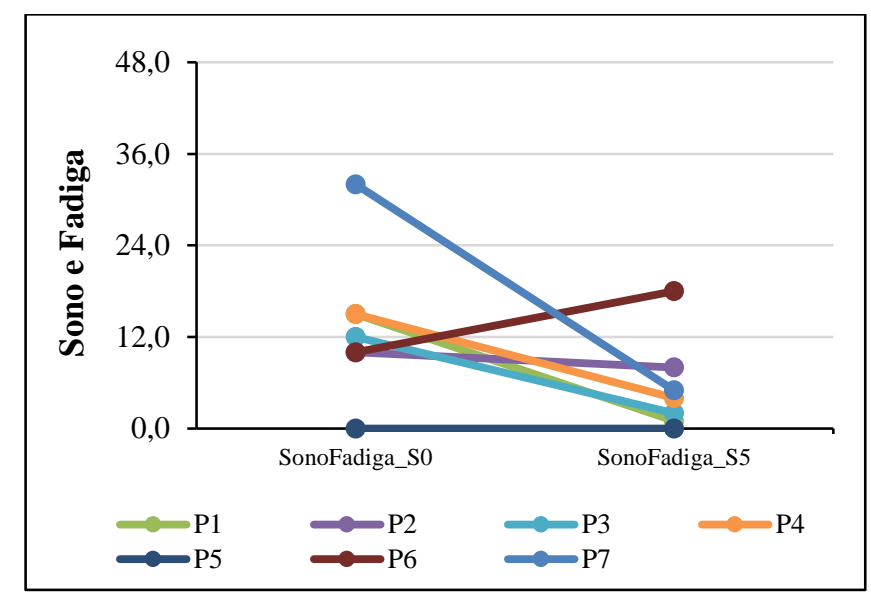

Gráfico 10: Resultados obtidos NMSS -domínio sono e fadiga (antes e depois)

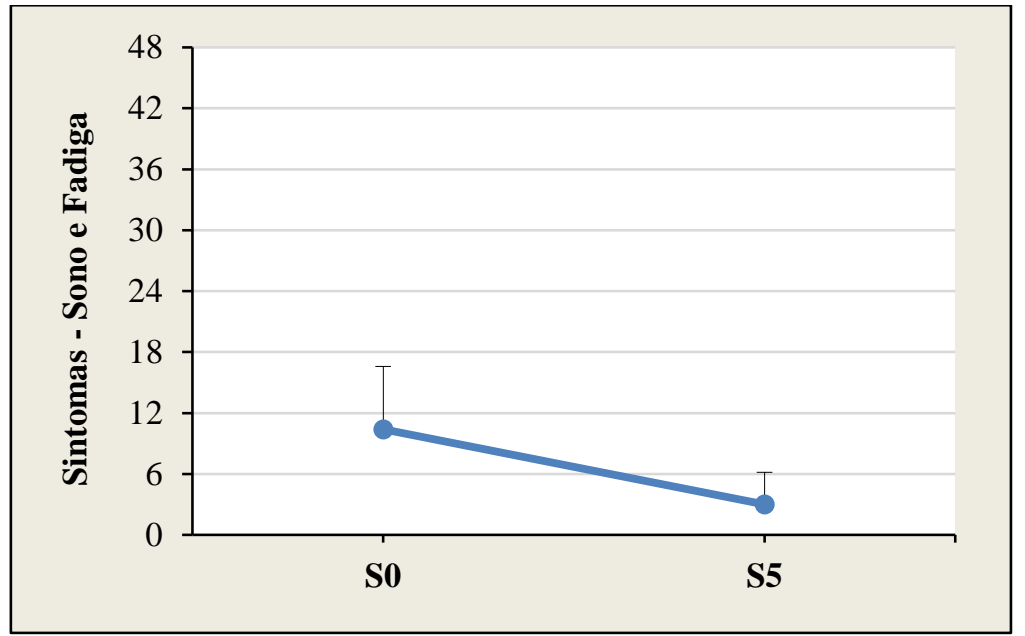

Gráfico 11: Resultados obtidos após estatística (NMSS - domínio sono e fadiga): Média e DP dos valores, antes (S0) e após cinco sessões de acupuntura (S5). Teste t-Student pareado, $p=0,072$.

No domínio humor e cognição (Tabela 5 e gráficos 12 e 13), não foi detectado efeito significante das cinco sessões de acupuntura, $p=0,236$.

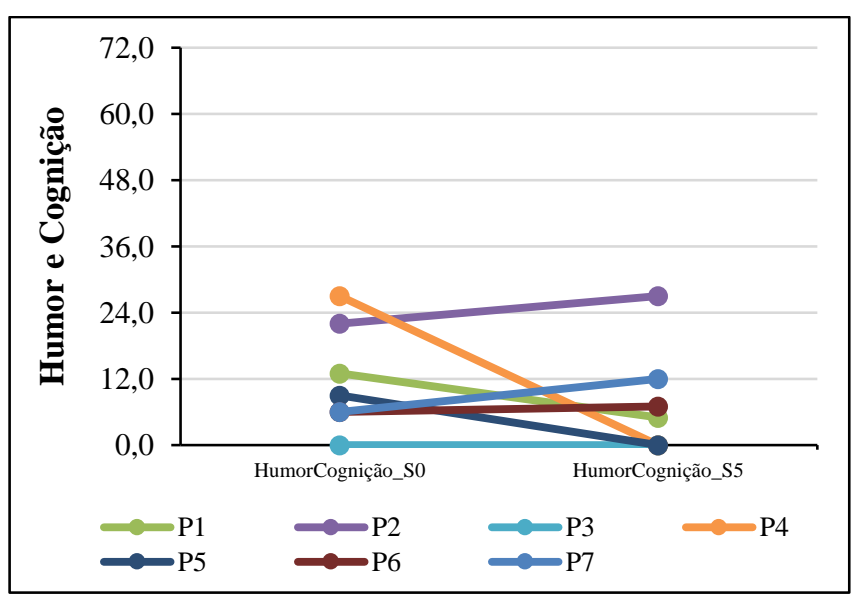

Gráfico 12: Resultados obtidos NMSS -domínio humor e cognição (antes e depois) 


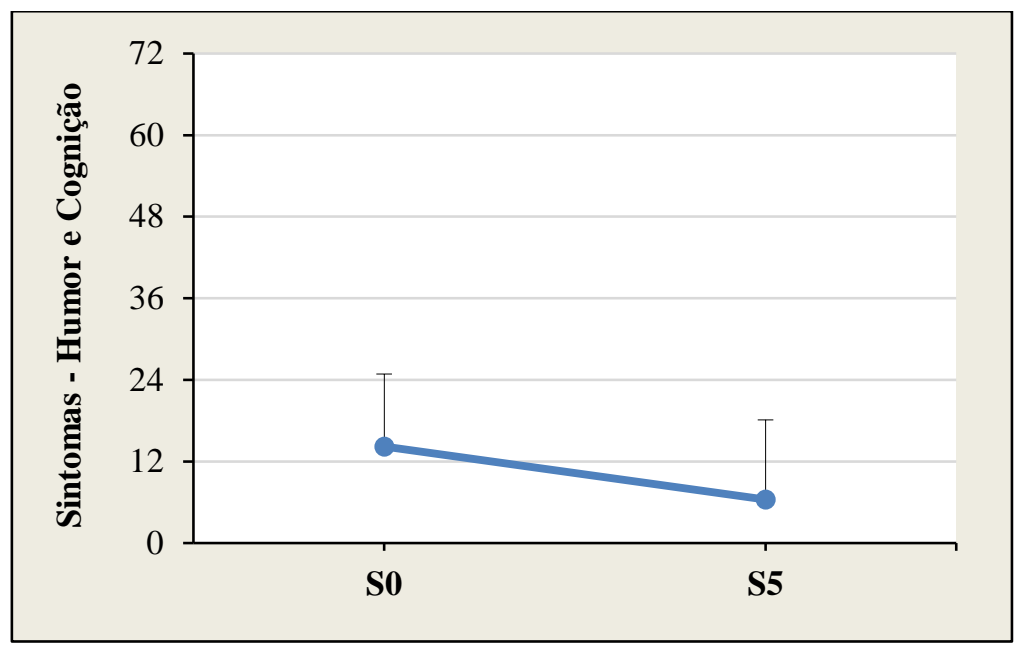

Gráfico 13: Resultados obtidos após estatística (NMSS - domínio humor e cognição): Média e DP dos valores, antes (S0) e após cinco sessões de acupuntura (S5). Teste t-Student pareado, $p=0,236$.

No domínio percepção e alucinação (Tabela 5 e gráficos 14 e 15), não foi detectado efeito significante das cinco sessões de acupuntura, $p=1,000$.

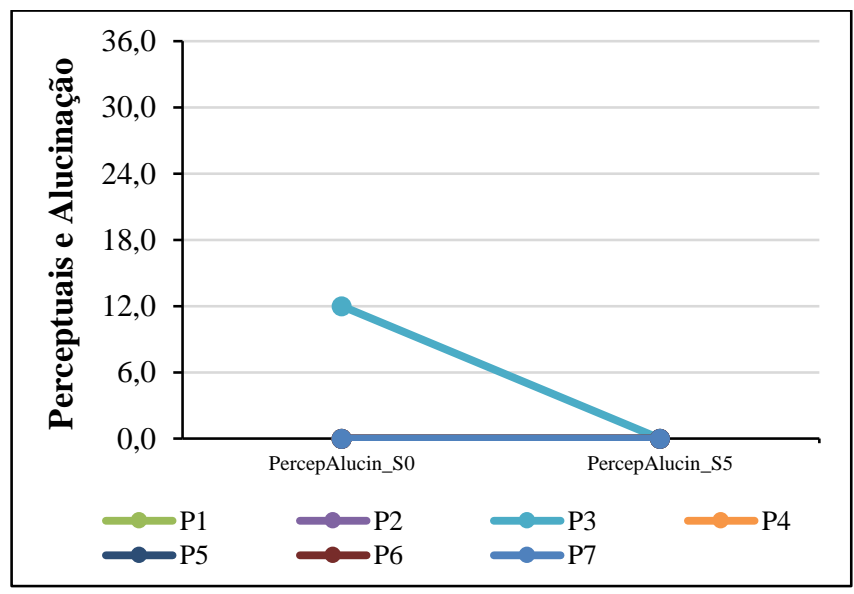

Gráfico 14: Resultados obtidos NMSS -domínio percepção e alucinação (antes e depois) 


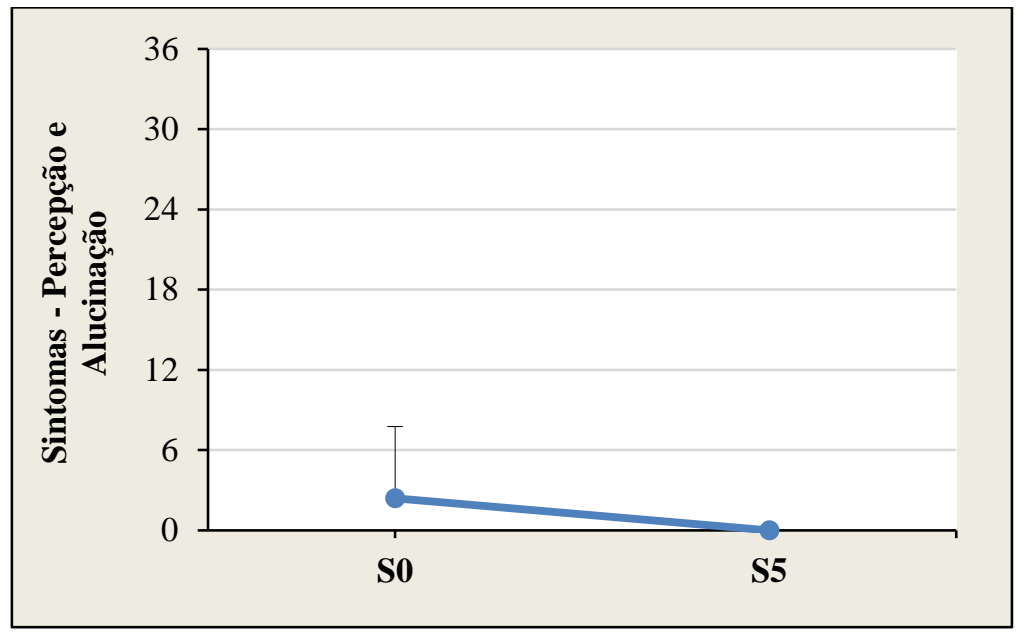

Gráfico 15: Resultados obtidos após estatística (NMSS - domínio percepção e alucinação): Média e DP dos valores, antes (S0) e após cinco sessões de acupuntura (S5). Teste tStudent pareado, $p=0,236$.

No domínio atenção e memória (Tabela 5 e gráficos 16 e 17), não foi detectado efeito significante das cinco sessões de acupuntura, $p=0,553$.

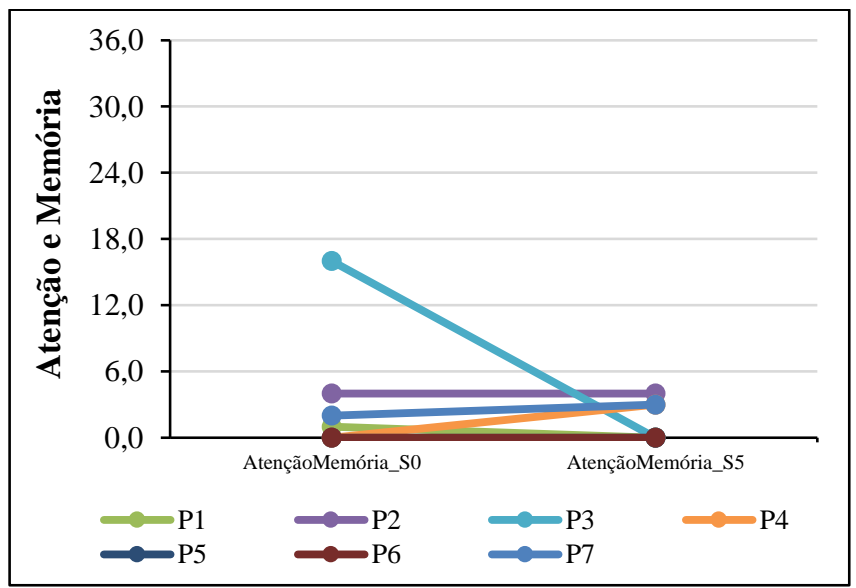

Gráfico 16: Resultados obtidos NMSS -domínio atenção e memória (antes e depois) 


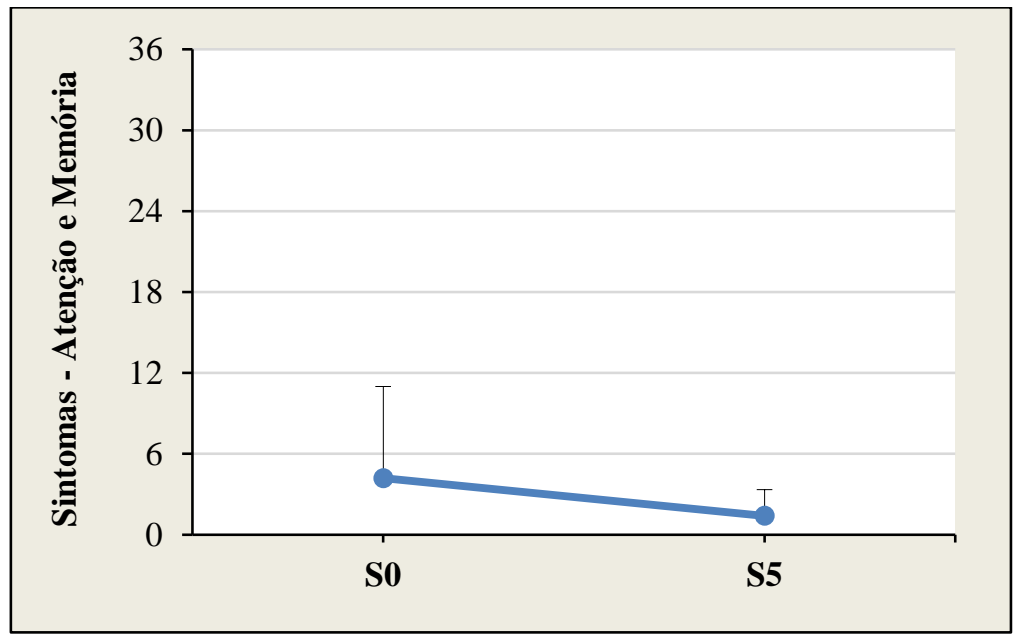

Gráfico 17: Resultados obtidos após estatística (NMSS - domínio atenção e memória): Média e DP dos valores, antes (S0) e após cinco sessões de acupuntura (S5). Teste t-Student pareado, $p=0,553$.

Assim como nos domínios anteriores, também não foi significante o efeito das cinco sessões de acupuntura para os domínios gastrointestinal (gráficos 18 e 19), $p=0,054$; urinário (gráfico 20 e 21), $p=0,399$ e função sexual (gráfico 22 e 23), $p=1,000$; miscelânea (gráfico 24 e 25), $p=0,229$. Resultados descritivos, Tabela 5.

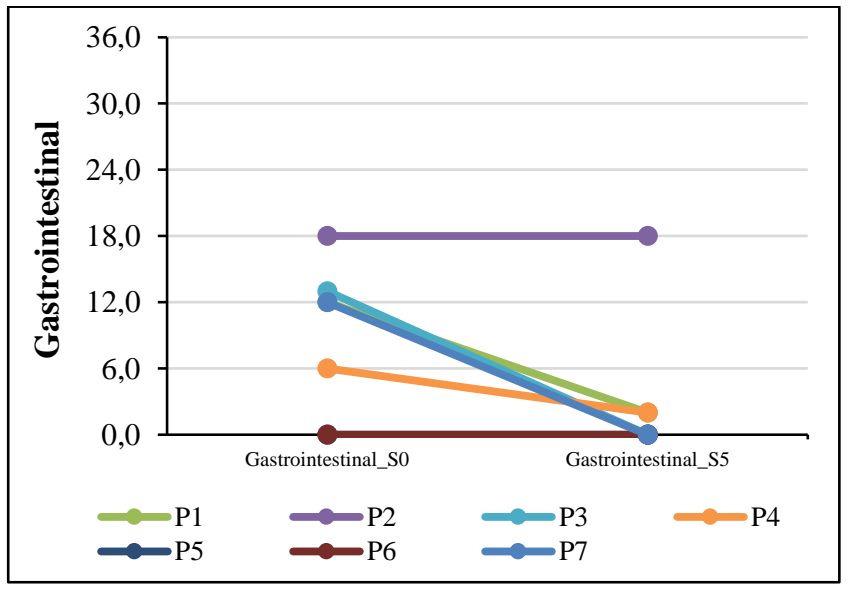

Gráfico 18: Resultados obtidos NMSS -domínio gastrointestinal (antes e depois) 


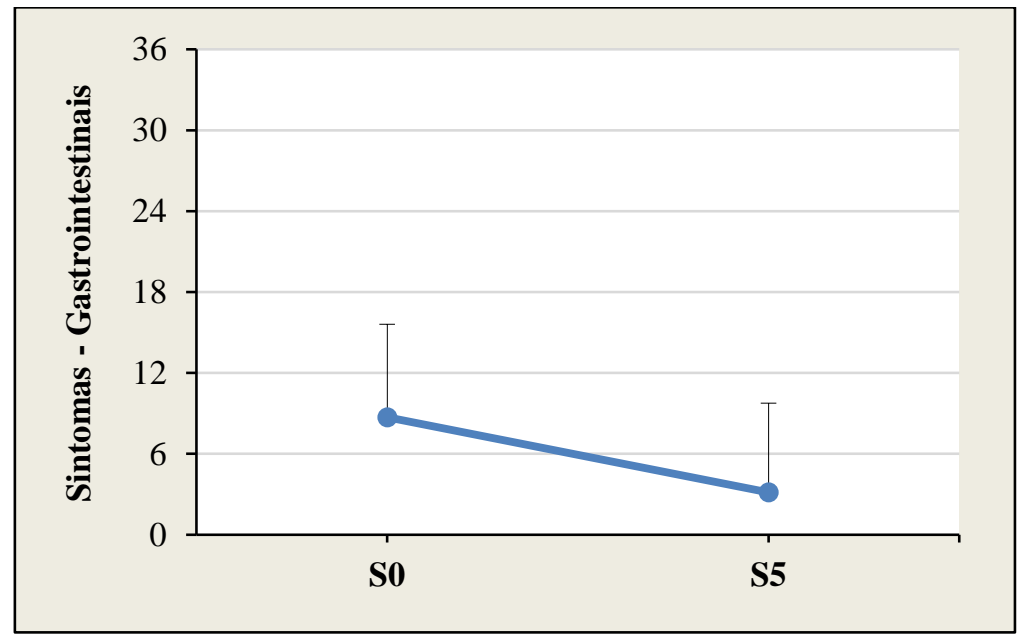

Gráfico 19: Resultados obtidos após estatística (NMSS - domínio gastrointestinal): Média e DP dos valores do sintoma, antes (S0) e após cinco sessões de acupuntura (S5). Teste t-Student pareado, $p=0,054$.

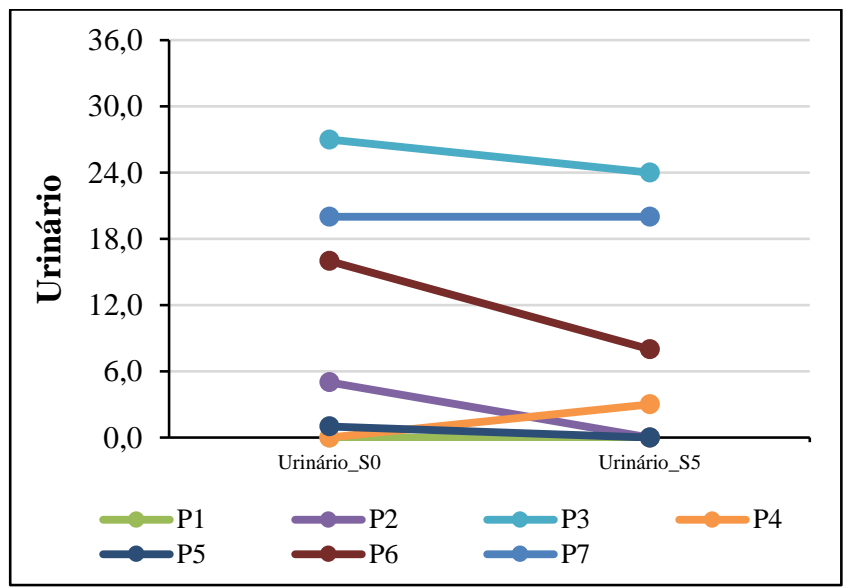

Gráfico 20: Resultados obtidos NMSS -domínio urinário (antes e depois)

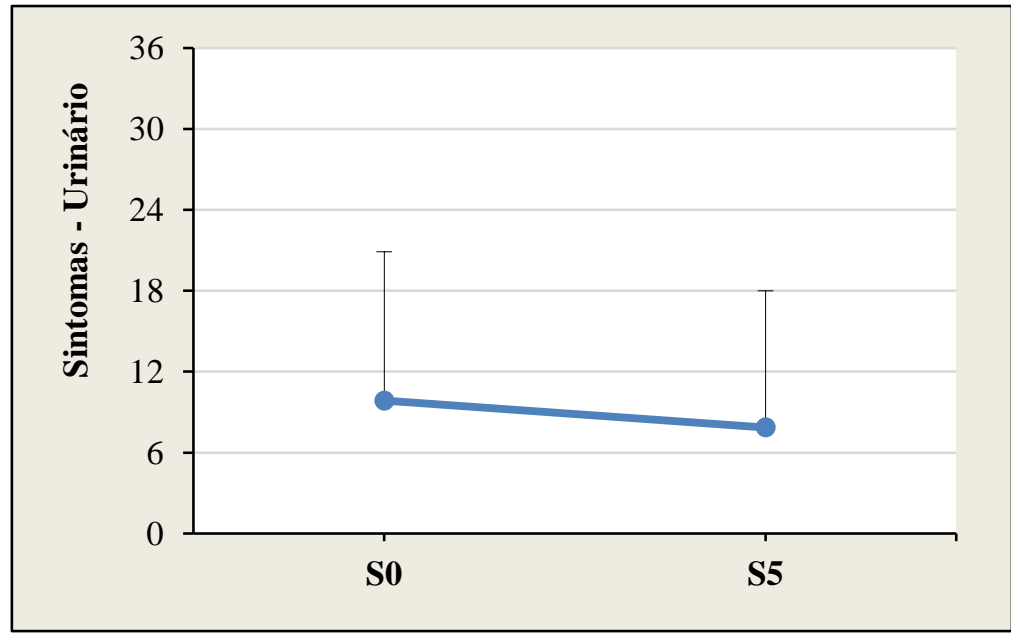

Gráfico 21: Resultados obtidos após estatística (NMSS - domínio urinário): Média e DP dos valores do sintoma não motor - Urinário, antes (S0) e após cinco sessões de acupuntura (S5). Teste t-Student pareado, $p=0,399$. 


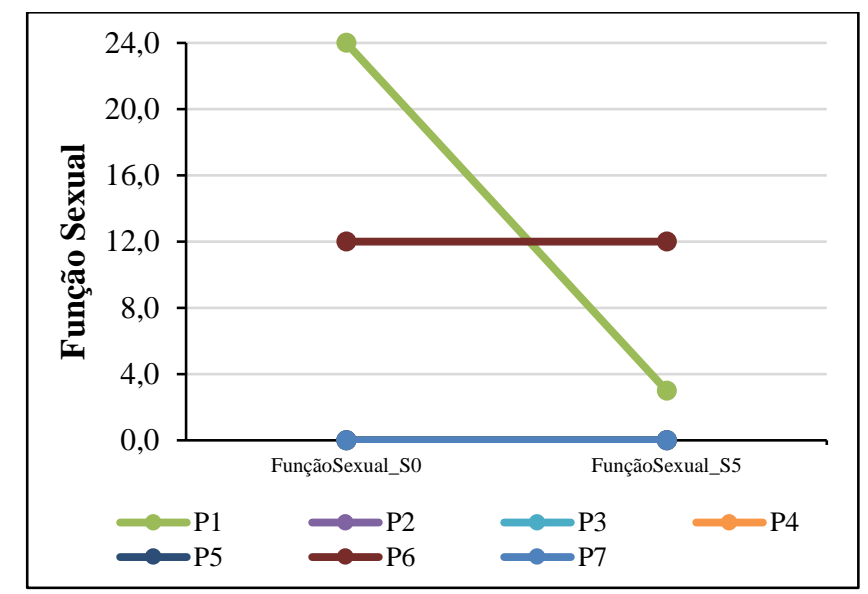

Gráfico 22: Resultados obtidos NMSS -domínio função sexual (antes e depois)

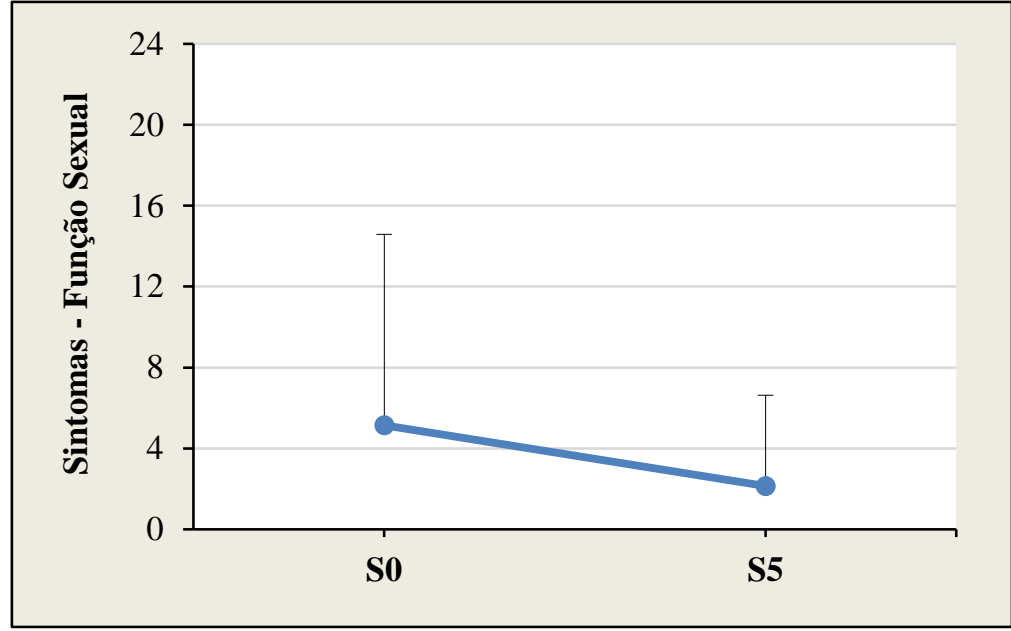

Gráfico 23: Resultados obtidos após estatística (NMSS - domínio função sexual): Média e DP dos valores do sintoma, antes (S0) e após cinco sessões de acupuntura (S5). Teste de Wilcoxon, $p=1,000$.

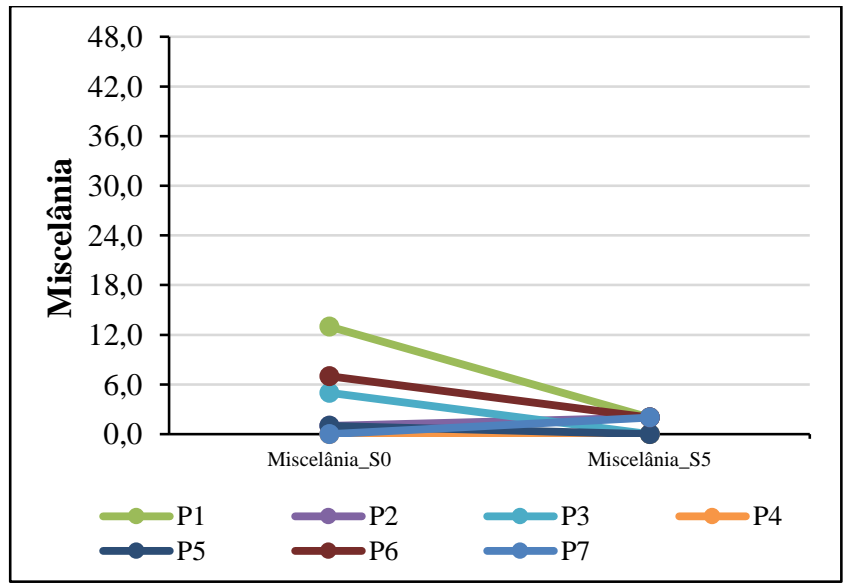

Gráfico 24: Resultados obtidos NMSS -domínio miscelânea (antes e depois) 


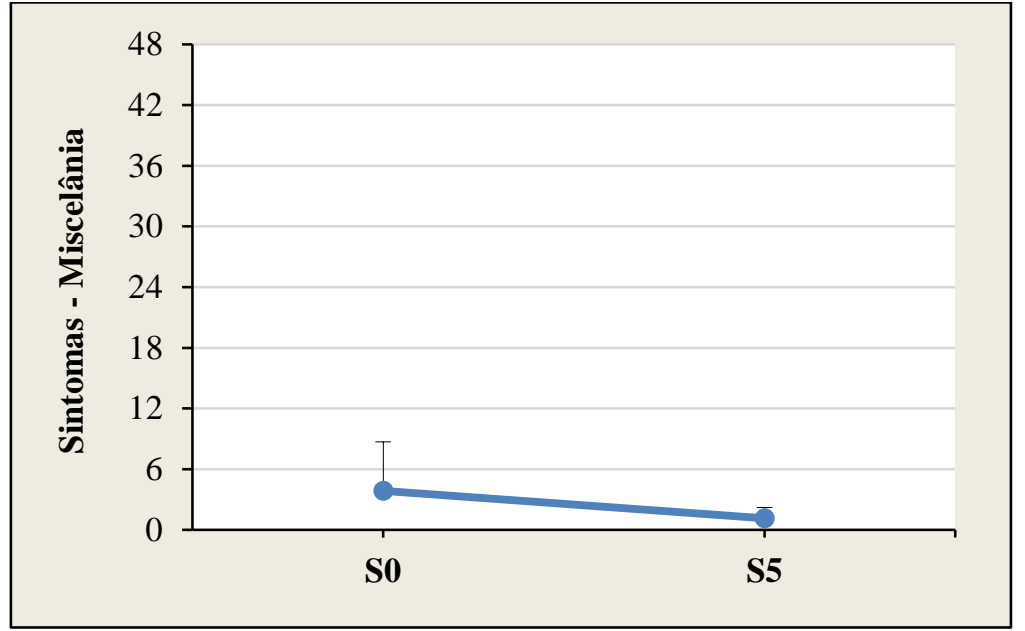

Gráfico 25: Resultados obtidos após estatística (NMSS - domínio miscelânea): Média e DP dos valores do sintoma, antes (S0) e após cinco sessões de acupuntura (S5). Teste t-Student pareado, $p=0,229$.

O domínio total (Tabela 5, gráficos 26 e 27), onde todas as respostas do teste são analisadas em conjunto, observou-se uma diminuição significante dos sintomas após cinco sessões de acupuntura, $p=0,010$.

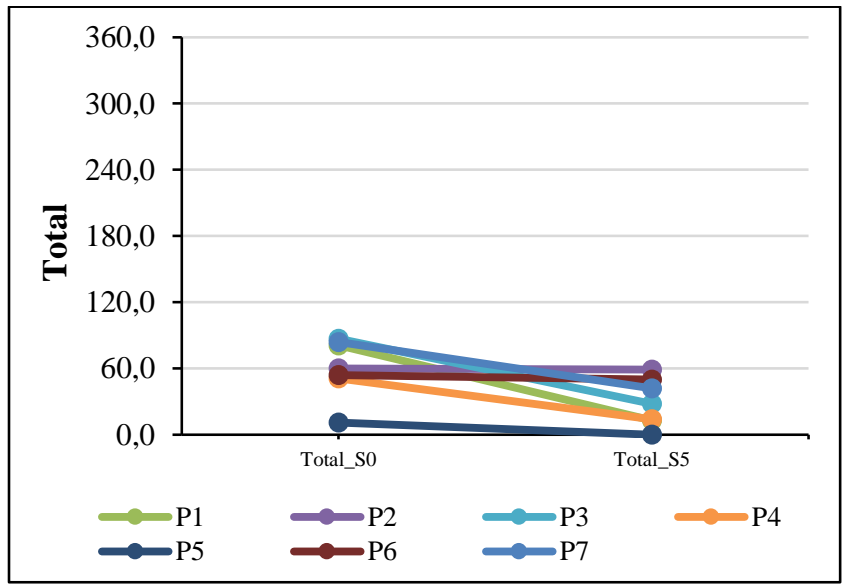

Gráfico 26: Resultados obtidos NMSS - Total (antes e depois) 


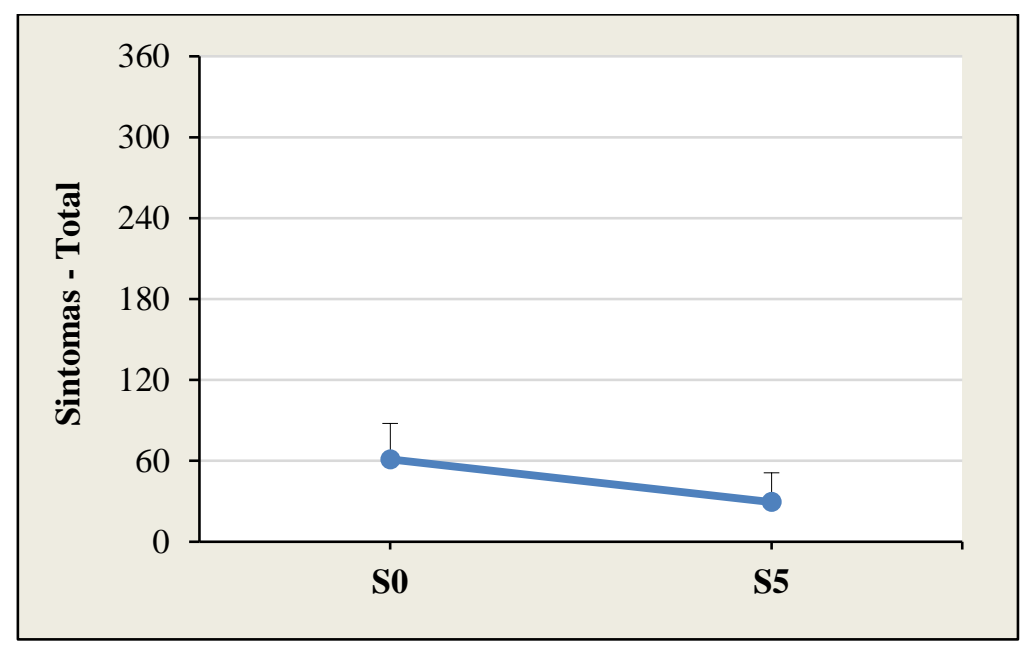

Gráfico 27: Resultados obtidos após estatística (NMSS - Total): Média e DP dos valores do sintoma, antes (S0) e após cinco sessões de acupuntura (S5). Teste t-Student pareado, S5₹S0, p=0,010.

Por último foi realizada a análise do questionário de qualidade de vida (PDQ39), como na variável anterior, primeiramente foi realizada a análise de cada um dos domínios e posteriormente do seu valor total. Na Tabela 6 estão os valores descritivos dos domínios do questionário de qualidade de vida: mobilidade, atividade de vida diária, bem estar emocional, estigma, suporte social, cognição, comunicação, desconforto corporal e total. Todos os valores descritivos da análise estão demonstrados na tabela 6. 


\begin{tabular}{|c|c|c|c|c|}
\hline Domínio & Sessão & Média & DP & $\mathrm{N}$ \\
\hline \multirow{2}{*}{ Mobilidade } & so & 53,57 & 24,95 & 7 \\
\hline & S5 & 41,79 & 18,58 & 7 \\
\hline \multirow{2}{*}{$\begin{array}{l}\text { Atividade de Vida } \\
\text { Diária }\end{array}$} & so & 50,53 & 23,41 & 7 \\
\hline & S5 & 39,13 & 14,78 & 7 \\
\hline \multirow{2}{*}{$\begin{array}{l}\text { Bem Estar } \\
\text { Emocional }\end{array}$} & so & 46,40 & 18,40 & 7 \\
\hline & S5 & 30,29 & 15,61 & 7 \\
\hline \multirow{2}{*}{ Estigma } & so & 45,23 & 23,51 & 7 \\
\hline & S5 & 30,37 & 16,30 & 7 \\
\hline \multirow{2}{*}{ Suporte Social } & So & 65,34 & 10,10 & 7 \\
\hline & S5 & 57,00 & 21,94 & 7 \\
\hline \multirow{2}{*}{ Cognição } & so & 35,13 & 22,76 & 7 \\
\hline & S5 & 23,23 & 11,83 & 7 \\
\hline \multirow{2}{*}{ Comunicação } & So & 22,50 & 13,43 & 7 \\
\hline & S5 & 20,13 & 15,89 & 7 \\
\hline \multirow{2}{*}{$\begin{array}{l}\text { Desconforto } \\
\text { Corporal }\end{array}$} & so & 60,69 & 11,48 & 7 \\
\hline & S5 & 39,17 & 19,19 & 7 \\
\hline \multirow{2}{*}{ Total } & So & 47,39 & 14,85 & 7 \\
\hline & S5 & 35,87 & 9,87 & 7 \\
\hline
\end{tabular}

Tabela 6: Descrição estatística: Média, desvio-padrão e tamanho da amostra dos domínios do questionário de qualidade de vida - PDQ39: mobilidade, atividade de vida diária, bem estar emocional, estigma, suporte social, cognição, comunicação, desconforto corporal e total, antes (S0) e após cinco sessões de acupuntura (S5). Valores expressos em porcentagem.

Para os domínios, mobilidade (gráficos 28 e 29) e atividade de vida diária (gráficos 30 e 31), não foi detectado efeito significante das cinco sessões de acupuntura, $p=0,217$ e $p=0,067$, respectivamente. Já no domínio bem estar emocional (gráfico 32 e 33), houve efeito significante das cinco sessões de acupuntura, $p=0,040$. 


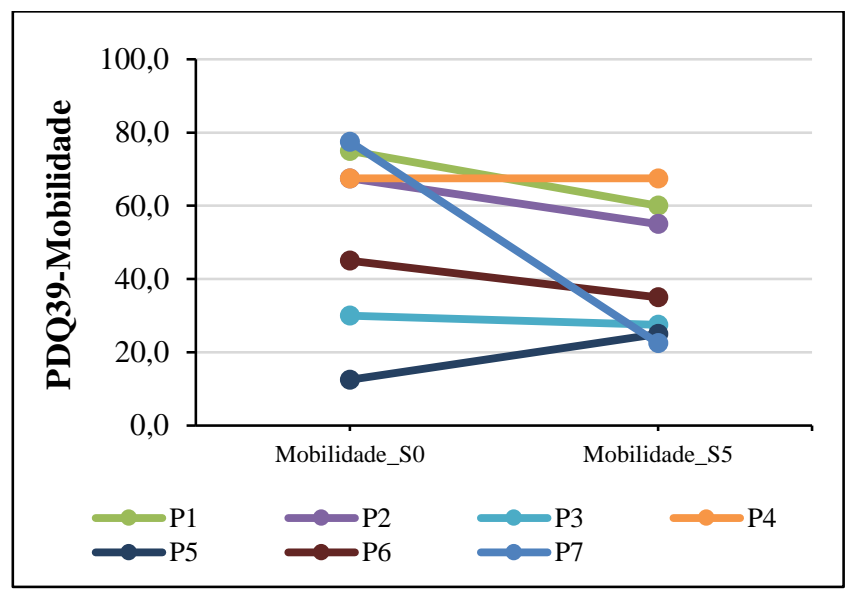

Gráfico 28: Resultados obtidos PDQ39 - domínio mobilidade (antes e depois)

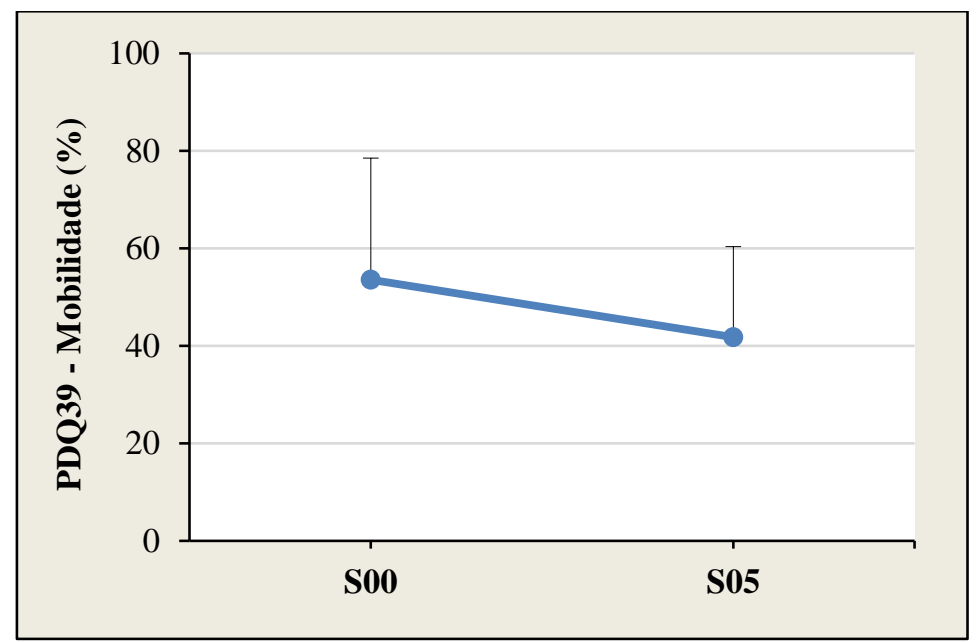

Gráfico 29: Resultados obtidos após estatística (PDQ39 - domínio mobilidade): Média e DP dos valores, antes (S0) e após cinco sessões de acupuntura (S5). Teste t-Student pareado, p=0,217.

Valores expressos em porcentagem.

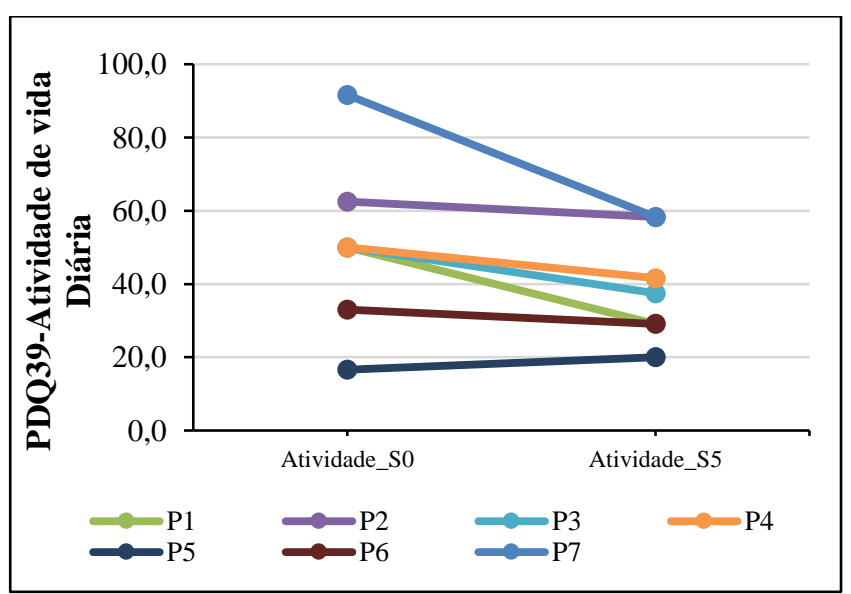

Gráfico 30: Resultados obtidos PDQ39 - atividade de vida diária (antes e depois) 


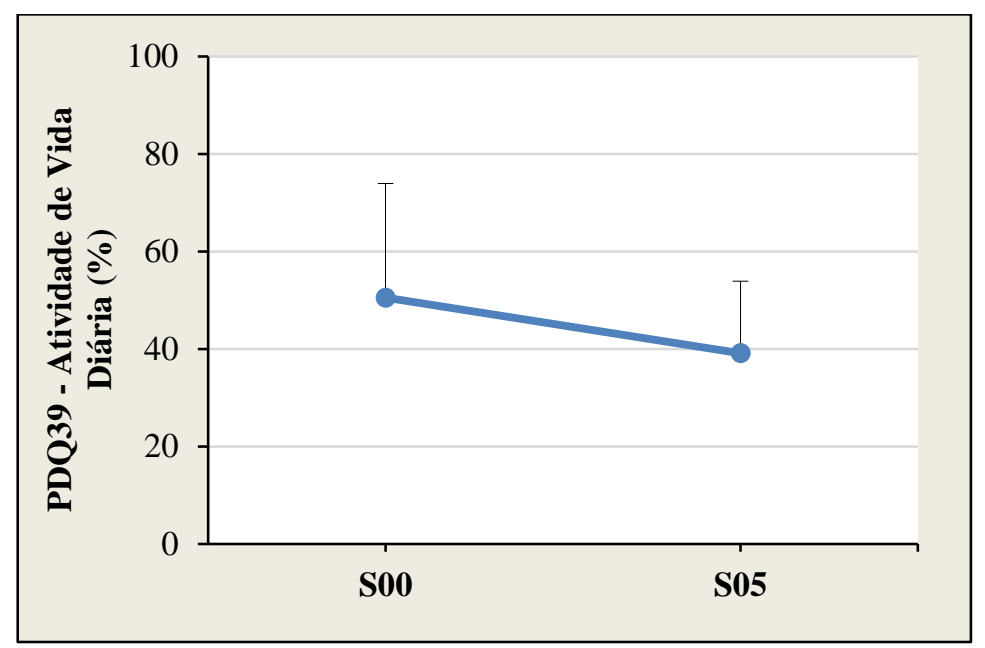

Gráfico 31: Resultados obtidos após estatística (PDQ39 - domínio atividade de vida diária): Média e DP dos valores, antes (S0) e após cinco sessões de acupuntura (S5). Teste t-Student pareado, $p=0,067$. Valores expressos em porcentagem.

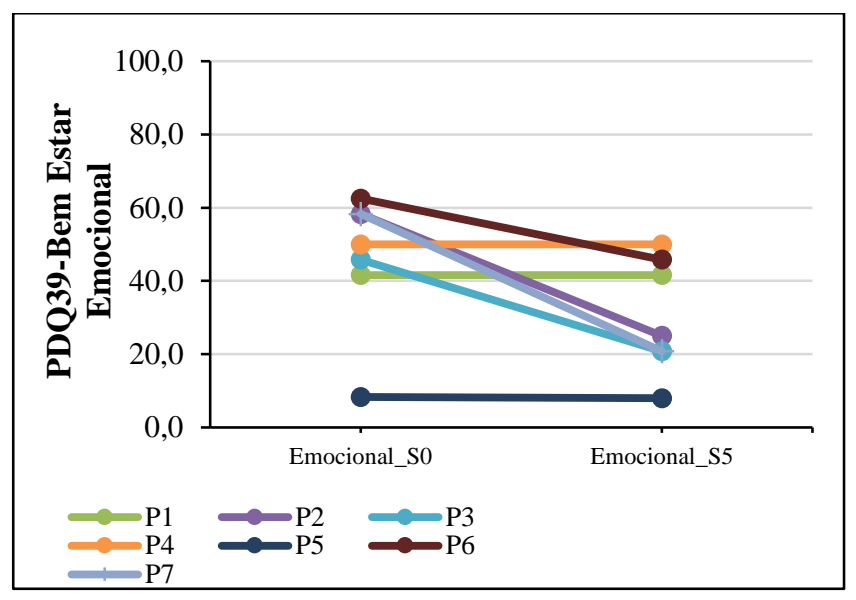

Gráfico 32: Resultados obtidos PDQ39 - domínio bem estar emocional (antes e depois)

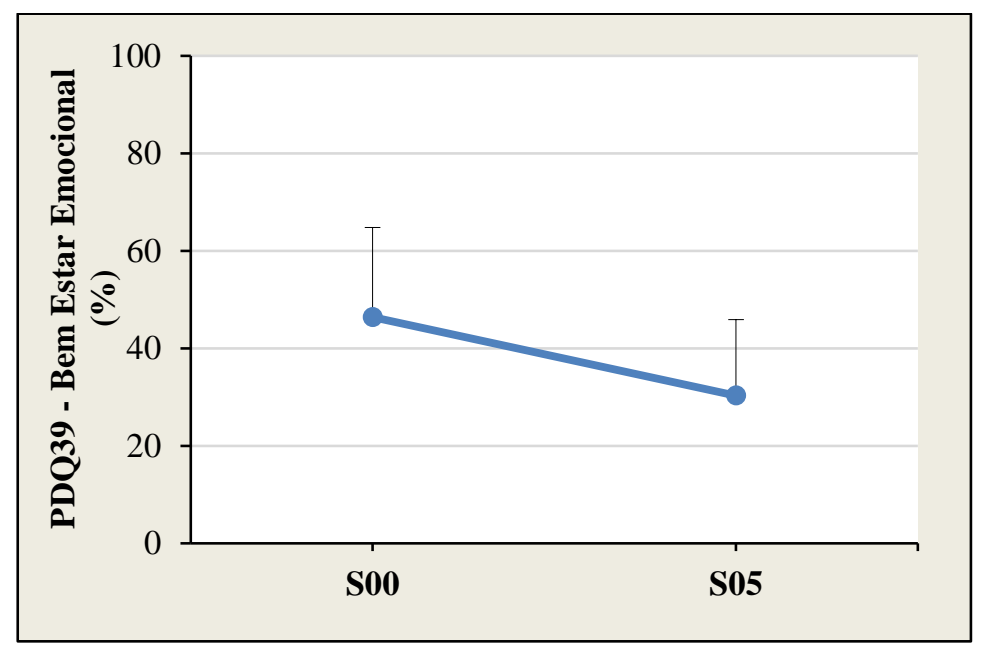

Gráfico 33: Resultados obtidos após estatística (PDQ39 - domínio bem estar emocional): Média e DP dos valores, antes (S0) e após cinco sessões de acupuntura (S5). Teste t-Student pareado, S5₹S0, $p=0,040$. Valores expressos em porcentagem. 
Não foi detectado efeito significante das cinco sessões de acupuntura para os domínios estigma (gráficos 34 e 35), p=0292; suporte social (gráfico 36 e 37), $p=1,000$ e cognição (gráfico 38 e 39), $p=0,331$.

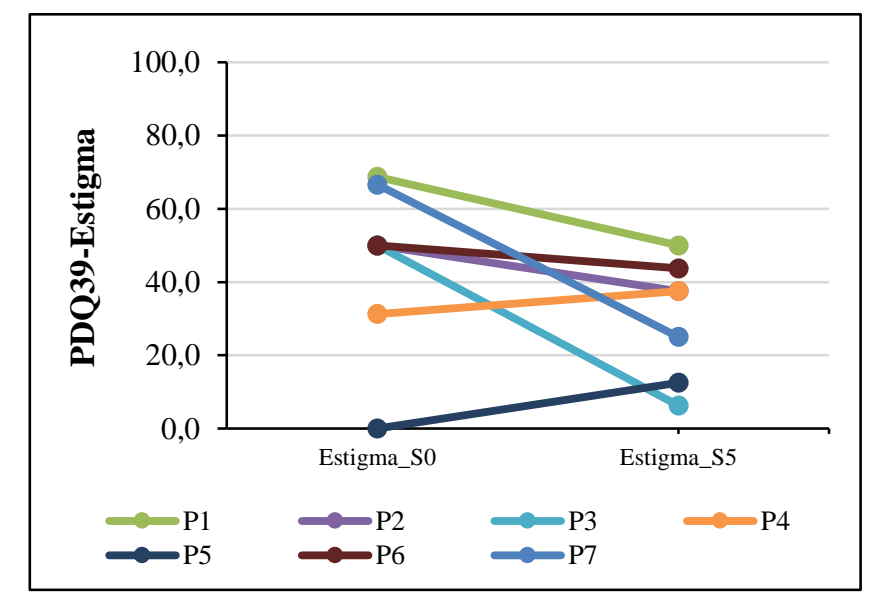

Gráfico 34: Resultados obtidos PDQ39 - domínio estigma (antes e depois)

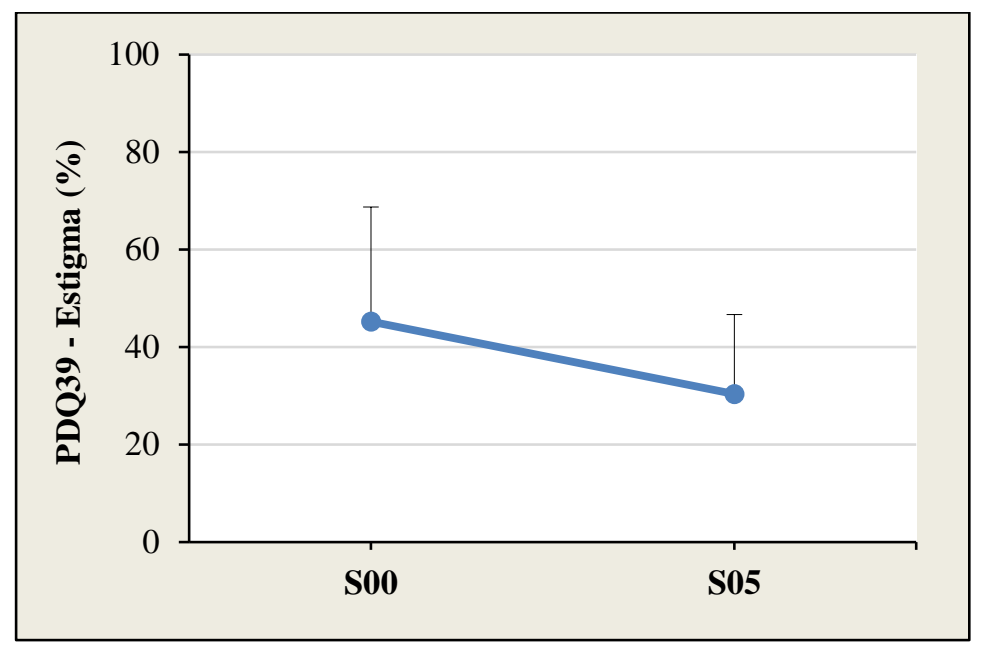

Gráfico 35: Resultados obtidos após estatística (PDQ39 - domínio estigma): Média e DP dos valores, antes (S0) e após cinco sessões de acupuntura (S5). Teste t-Student pareado, $p=0,292$. Valores expressos em porcentagem. 


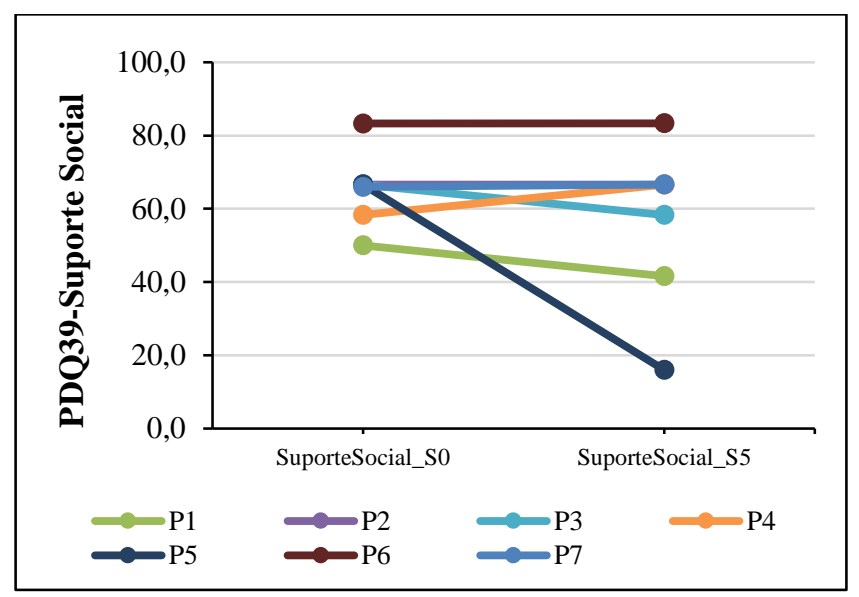

Gráfico 36: Resultados obtidos PDQ39 - domínio suporte social (antes e depois)

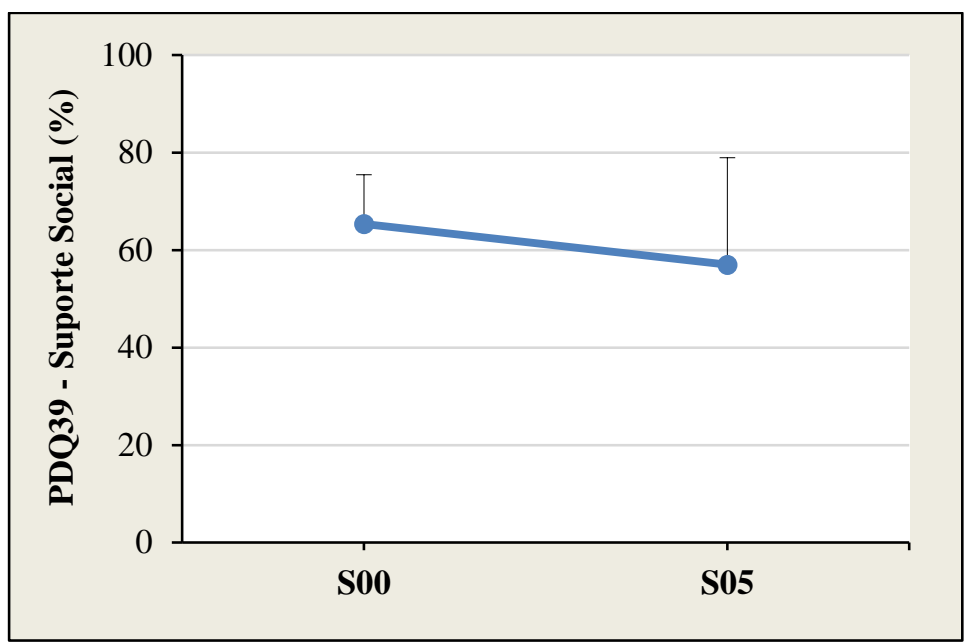

Gráfico 37: Resultados obtidos após estatística (PDQ39 - domínio suporte social): Média e DP dos valores, antes (S0) e após cinco sessões de acupuntura (S5). Teste de Wilcoxon, $p=1,000$. Valores expressos em porcentagem.

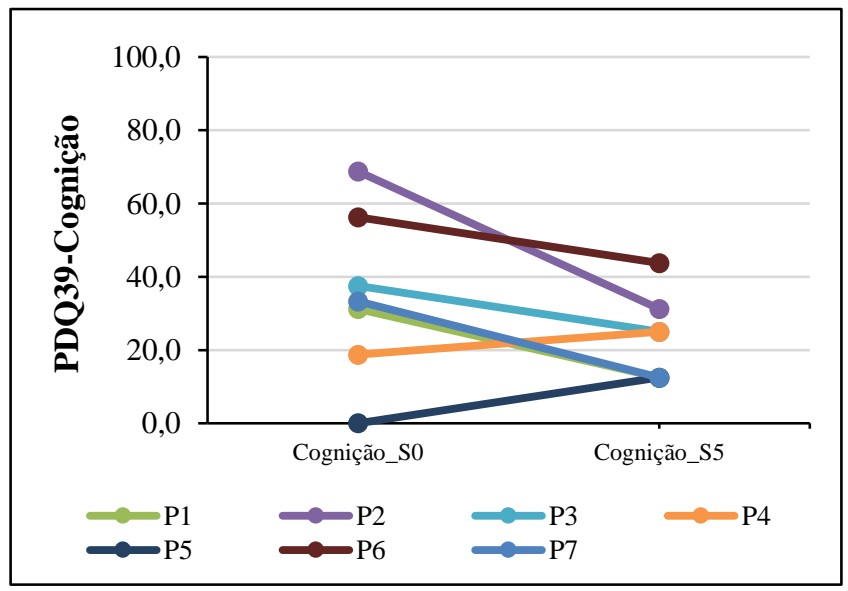

Gráfico 38: Resultados obtidos PDQ39 - domínio cognição (antes e depois) 


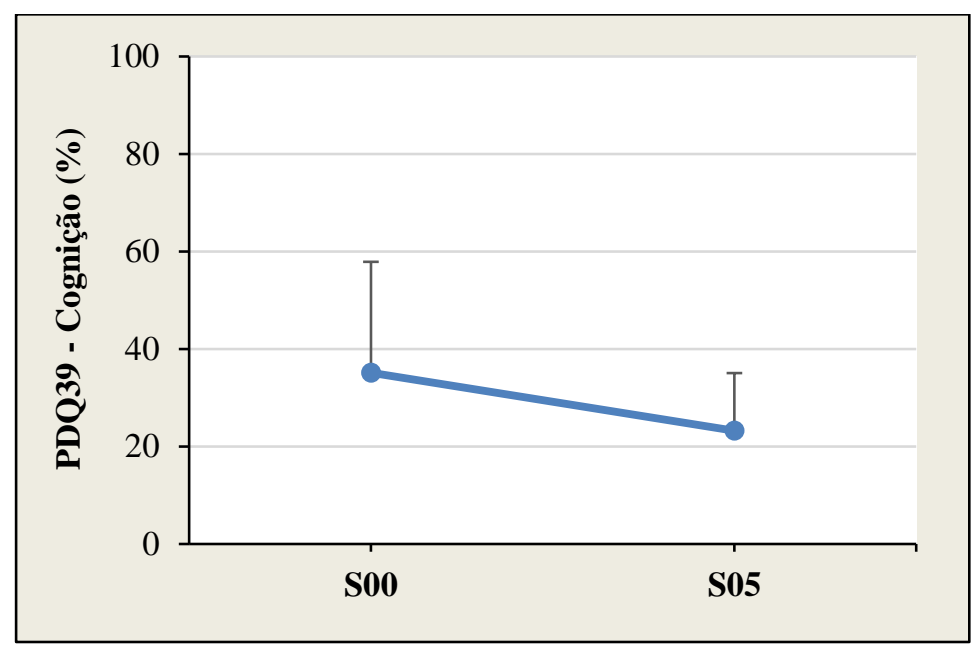

Gráfico 39: Resultados obtidos após estatística (PDQ39 - domínio cognição): Média e DP dos valores, antes (S0) e após cinco sessões de acupuntura (S5). Teste t-Student pareado, $p=0,331$.

Valores expressos em porcentagem.

Por fim o domínio comunicação (gráfico 40 e 41) não foi detectado efeito significante das cinco sessões de acupuntura, $p=0,703$. No domínio desconforto corporal (gráfico 42 e 43), houve efeito significante das cinco sessões de acupuntura, $p=0,009$. O domínio total do PDQ39 (gráfico 44 e 45) também mostrou um efeito significante das cinco sessões de acupuntura, $p=0,029$.

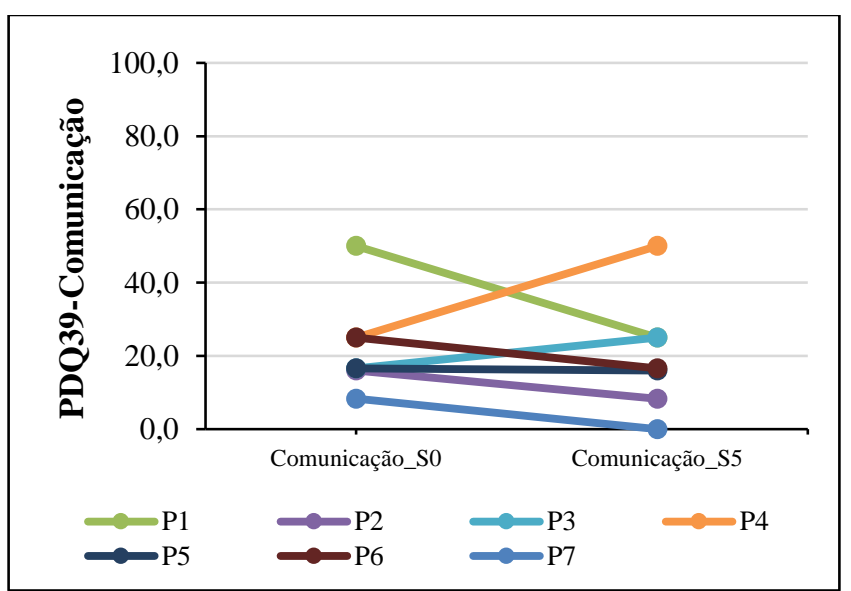

Gráfico 40: Resultados obtidos PDQ39 - domínio comunicação (antes e depois) 


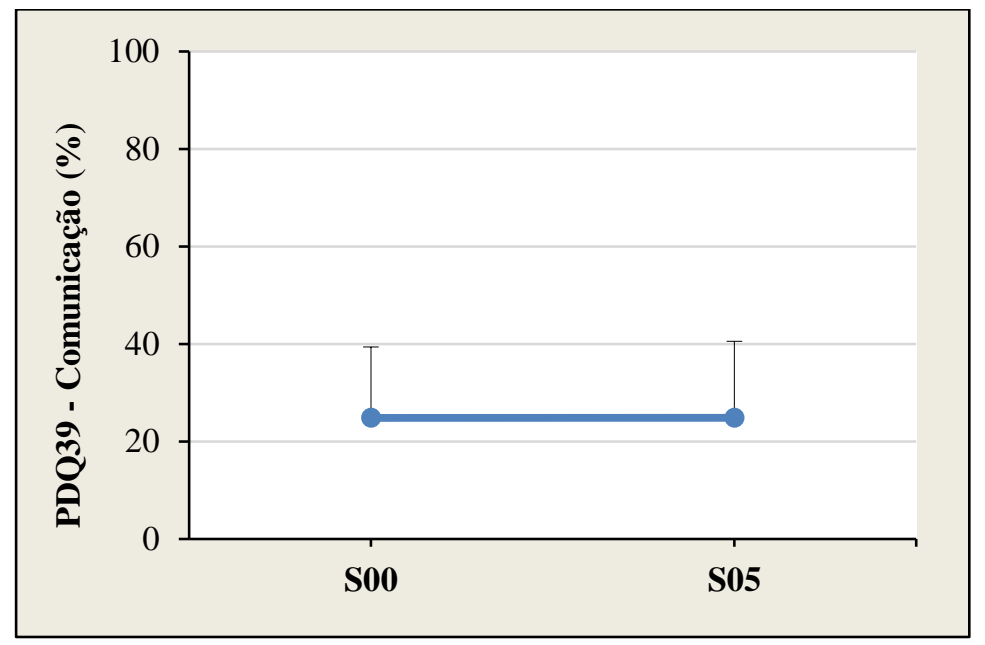

Gráfico 41: Resultados obtidos após estatística (PDQ39 - domínio comunicação): Média e DP dos valores, antes (S0) e após cinco sessões de acupuntura (S5). Teste t-Student pareado, $p=0,703$.

Valores expressos em porcentagem.

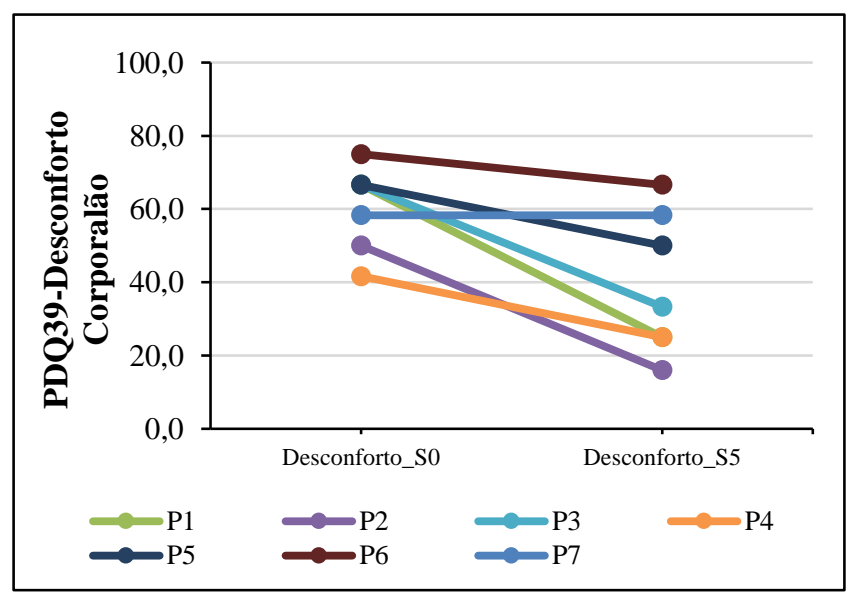

Gráfico 42: Resultados obtidos PDQ39 - domínio desconforto corporal (antes e depois)

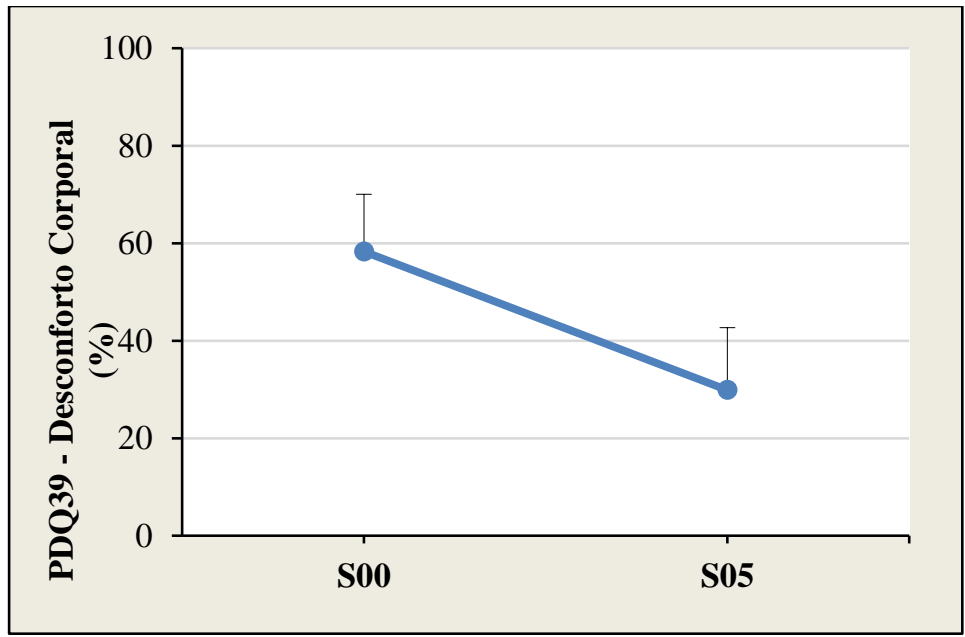

Gráfico 43: Resultados obtidos após estatística (PDQ39 - domínio desconforto corporal): dia e DP dos valores, antes (S0) e após cinco sessões de acupuntura (S5). Teste t-Student pareado, S5₹S0, $p=0,009$. Valores expressos em porcentagem 


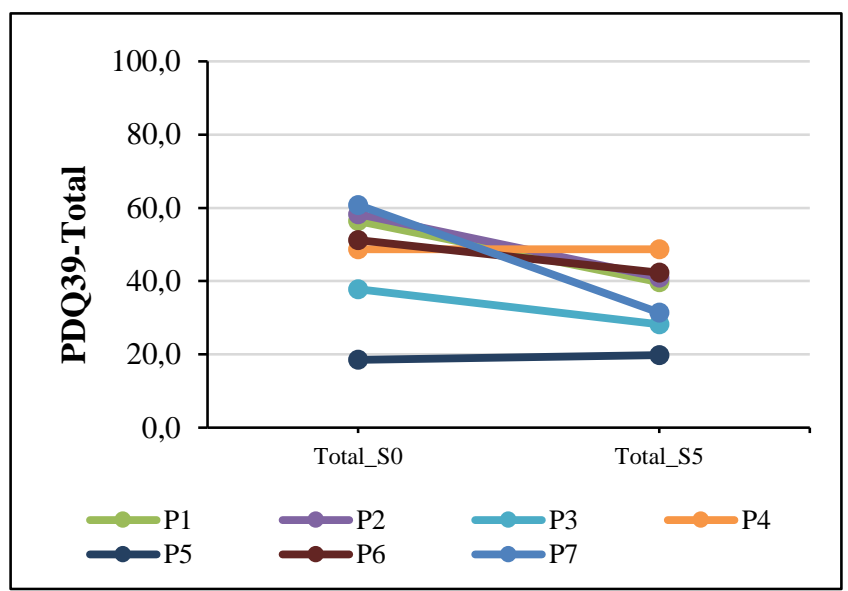

Gráfico 44: Resultados obtidos PDQ39 - Total (antes e depois)

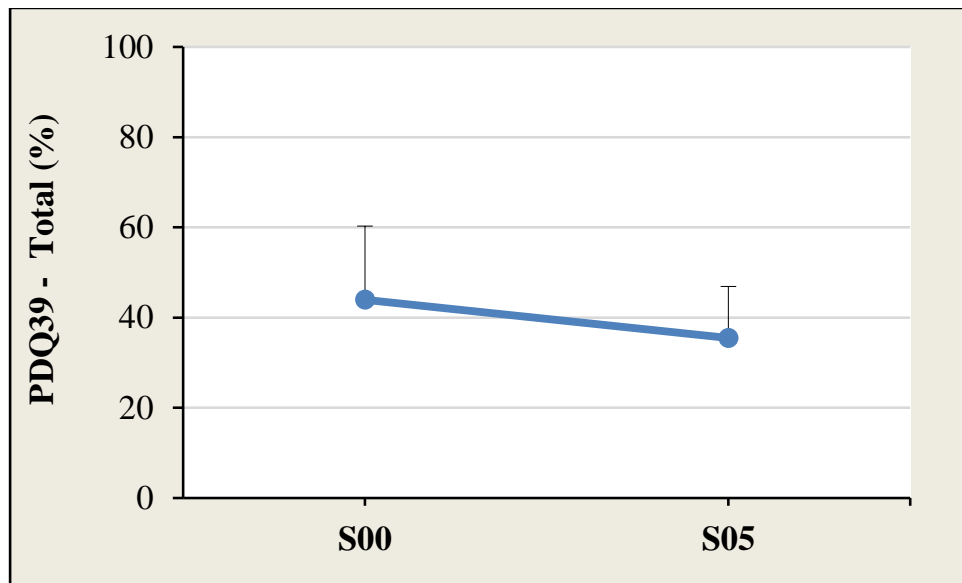

Gráfico 45: Resultados obtidos após estatística (PDQ39 - Total): Média e DP dos valores, antes (S0) e após cinco sessões de acupuntura (S5). Teste t-Student pareado, $S 5 \neq S 0, p=0,029$. Valores expressos em porcentagem. 


\section{5 - Discussão}

A utilização da acupuntura para a dor é um dos temas mais abordados quando realizamos uma varredura nos sistemas de cadastro de publicações, amplamente utilizada para esse fim. Sabe -se, que sua atuação sobre dores em diversos locais do corpo é efetiva, como relatada por Lai e Lin (2019), em um estudo atual de revisão bibliográfica, no qual são abordados os possíveis mecanismos relatados e envolvidos para a ação analgésica da acupuntura na dor aguda e crônica. Dentre os mecanismos por eles relatados existe a teoria de inibição segmentar da comporta medular, como também citado e estudado por Alltree em 1993; Carlsson em 2002 e Muchtadi e col.em 2009, que descreveram que tal efeito poderia ser o responsável pelo alivio imediato. Estudos duplos cegos em pacientes com dor miofascial também descreveram a modulação segmentar como um mecanismo importante para a ação da acupuntura (SRBERLY, LEED AND LOWERISON, 2010)

Ainda citando Lai e Lin (2019) eles relatam a possível ativação das vias endógenas de opióides, com experimentos tanto utilizando somente a inserção de agulhas como a associação das agulhas com eletroacupuntura, descreveram a liberação das encefalinas, beta-endorfinas e endorfinas como o grande achado para a máxima terapêutica causada pela acupuntura. Carlsson em 2002 e Kagitani.Stener-Victorin. Wu em 2010, também investigaram os efeitos relacionados a liberação de neurotransmissores atuantes nas vias supra espinhais justificando os efeitos analgésicos que podem permanecer ativos por oito horas.

Lai e Lin (2019) em sua revisão abordam diversos outras suspeitas de vias possíveis para a analgesia mediada pela acupuntura como: ativação das vias adrenérgicas, serotoninérgicas, glutamatérgicas, além da redução da liberação local de substâncias inflamatórias Quase todos esses itens abordados anteriormente neste trabalho. Portanto não surpreende que os sujeitos desta pesquisa tenham relatado melhora na escala visual analógica de dor e que tal melhora após a análise estatística tenha apresentado efeito significante, indo de encontro ao que é descrito na literatura.

Quando pensamos em sintomas motores a utilização da UPDRS parte III é o padrão ouro para isso, e os dados nesta pesquisa nos mostraram que a acupuntura apresentou um efeito significante na diminuição dos scores independente se o 
paciente estava no momento off medicação ou on medicação. Tal achado vai de encontro com relatos na literatura na qual a acupuntura foi efetiva no alivio de sintomas motores. Wang e col., 2011, em seu estudo com animais e utilizando eletroacupuntura observaram melhora nos padrões motores de seus animais. Nam Kim (2013) descreveram um efeito interativo entre a acupuntura e a utilização da levodopa, porem tal efeito integrativo não foi encontrado neste trabalho. Park e col. (2015) também descreveram uma via que justificasse a melhora motora por ele obtida, em seu trabalho utilizando modelos animais, dados que vão de encontro aos encontrados no presente estudo. O efeito da medicação independente da acupuntura é retórico, visto a utilização da levodopa no tratamento e controle da doença.

Quanto ao resultado do teste mini mental era esperado que não houvesse alteração, visto que o declínio em sua pontuação poderia sugerir uma piora no quadro cognitivo deste paciente e uma possível progressão da doença. Por seus valores serem altos e mantidos, pode se concluir que a amostra era homogênea quanto aos padrões cognitivos e que não houve piora durante o estudo.

Analisando sobre os dados encontrados na escala de sintomas não motores (NMSS) e na escala de qualidade de vida (PDQ39) quando visualizamos cada um dos domínios não conseguimos de maneira geral encontrar diferenças significantes nos scores antes e depois da quinta sessão realizada. Existindo somente duas exceções encontradas no PDQ39, no domínio relacionado a bem estar emocional e no domínio desconforto corporal, ambos apresentando intrínseca relação com o alivio da dor, já discutido anteriormente, sugerindo assim que a melhora na dor leva a uma melhora no estado emocional e melhora no desconforto corporal deste meu paciente.

Mas intrigantemente quando analisamos ambas as escalas em sua totalidade, encontramos diferenças significantes entre o momento zero (antes da realização da acupuntura) e momento cinco (após a quinta sessão). Talvez esse resultado se deva ao fato de que pequenas melhoras em cada domínio não são significantes, mas que quando analisamos o total observamos a melhora geral deste meu paciente. A melhora na qualidade de vida e nos sintomas não motores vai de encontro ao relatado por Kim e Jeon (2014) que relataram melhora em diversos aspectos como 
nos sintomas depressivos, na qualidade de vida e nos sintomas motores dos sujeitos em sua pesquisa.

Este trabalho apresentou problemas em sua coleta de dados, principalmente quando pensamos na montagem de protocolos dos pontos de acupuntura, sabe - se que o diagnóstico da medicina tradicional chinesa é diferente da medicina ocidental, portanto torna-se importante ressaltar a individualidade no tratamento, porém por outro lado torna-se difícil comparar scores se a abordagem for diferente. Novos estudos podem realizar ambos os diagnósticos (ocidental e oriental), abordando de forma mais individualizada o tratamento e possivelmente com um número maior de sujeitos, para confirmar os resultados encontrados neste estudo. 


\section{6 - Conclusão}

Concluímos que este trabalho evidência uma tendência significante de melhora na dor, dos sintomas motores, da NMSS e do PDQ39 quando comparados antes do tratamento e após a realização de apenas cinco sessões de acupuntura. Um número maior de pacientes poderiam ser incluídos em um estudo futuro para confirmar tais achados. A utilização de uma técnica relativamente de baixo custo, segura e acessível pode contribuir no tratamento desta doença que atinge tantos sistemas orgânicos, beneficiando de forma conjunta aos outros tratamentos, os que sofrem dela em todos os seus domínios.

Em suma, a acupuntura apresentou efeitos positivos significantes nos sintomas motores e não motores dos pacientes com doença de Parkinson, sendo efetiva no alivio da dor, na melhora motora e na qualidade de vida. 


\section{7 - Referências $^{1}$}

1. ALLTREE, J. Physiotherapy and acupuncture: practice in the UK. Complementary Therapies in Medicine 1;34-41, 1993.

2. ASSOCIAÇÃO BRASILEIRA DE NORMAS TÉCNICAS. NBR 10520: informação e documentação: citações em documentos: apresentação. Rio de Janeiro, 2002

3. BONNET, A.M. et al. Nonmotor Symptoms in Parkinson's Disease in 2012: Relevant Clinical Aspects. Hindawi Publishing Corporation Parkinson's Disease, Article ID 198316, doi:10.1155/2012/198316, 2012.

4. $\quad$ BRASIL, V. V. et al. Qualidade de vida de portadores de dores crônicas em tratamento com acupuntura. Revista Eletrônica de Enfermagem.10(2): 383394, 2008 Disponível em: http://www.fen.ufg/revista/v10/n2/v10n2a10.htm

5. CARLSSON, C. Acupuncture mechanisms for clinically relevant long term effects - reconsideration and hypothesis. Acupuncture in medicine 20(2-3); 82-99, 2002.

6. CHERKIN, D.C. et al. Efficacy of acupuncture for chronic low back pain: protocol for a randomized controlled trial. Trials, 9:10, 2008.

7. CHUNG, $\mathrm{S}$ et al. Insomnia and Sleepiness in Parkinson Disease: Associations with Symptoms and Comorbidities. Journal of Clinical Sleep Medicine 9(11):1131-1137, 2013.

8. COLVIN, L., FORBES, K., FALLON, M. Difficult pain.BMJ. 6; 332(7549): 1081-1083, 2006.

9. DENG, J. et al. Electroacupuncture remediates glial dysfunction and ameliorates neurodegeneration in the astrocytic a-synuclein mutant mouse model. Journal of Neuroinflammation. 12:103, 2015.

10. GARCIA, D.S.; FERNANDEZ, R.F. Impact of non-motor symptoms on health-related and perceived quality of life in Parkinson's disease. Journal of the Neurological Sciences 332; 136-140, 2013.

${ }^{1}$ De acordo com a Associação Brasileira de Normas Técnicas. NBR 6023 
11. GOLDMAN, B. Chronic pain and the search for alternative treatments. Can Med Assoc J 145 (5); 1991.

12. GRIGORY, C. et al. The timing of acupuncture stimulation does not influence anesthetic requirement. Anesth Anal. Author Manuscript PMC, 3 February 2006.

13. HASTY, J et al. Wavelets of excitability in sensory neurons. The Journal of Neurophysiology vol 86, no 4, 2097-2101 October 2001.

14. HELENE, M. L.; DAVID, L. C.; MARILYN, J. C. Mechanical signaling through connective tissue: a mechanism for the therapeutic effect of acupuncture. FASEB J. 15, 2275-2282, 2001.

15. HSIAO, S.H; TSAI,L.J. A neurovascular transmission model for acupuncture induced nitric oxide. J Acupunct Meridian Stud 1(1):42-50, 2008.

16. HUI, K. K. et al. Perception of Deqi by Chinese and American acupunturists: a pilot survey. CMJournal 6:2, 2011.

17. KAGITANI, F.; UCHIDA, S.; HOTTA, H. Afferent nerve fibers and acupuncture. Autonomic Neuroscience: Basic and Clinical 157: 2-8, 2010.

18. KHEDR, E.M. et al. Prevalence of non motor features in a cohort of Parkinson's disease patients. Clinical Neurology and Neurosurgery 115; 673677, 2013.

19. KOVÁCS, M. et al. Impact of Sex on the Non motor Symptoms and the Health-Related Quality of Life in Parkinson's Disease. Hindawi Publishing Corporation, http://dx.doi.org/10.1155/2016/7951840, 2016.

20. KIM, H.J. et al. Nonmotor symptoms in de novo Parkinson disease before and after dopaminergic treatment. Journal of the Neurological Sciences $287 ; 200-204,2009$.

21. KIM, S.N.et al. Acupuncture enhances the synaptic dopamine availability to improve motor function in a mouse model of Parkinson's disease. Journal PLoS ONE. 6(11), 2011. 
22. KIM, H. J., JEON, B. S. Is acupuncture efficacious therapy in Parkinson's disease? Journal of the Neurological Sciences 341; 1-7, 2014.

23. LAI, H. C., LIN, YI-WU. Acupuncture -analgesia - mediated alleviation of central sensitization. Evidence -based Complementary and alternative medicine 1-13, 2019.

24. LEONARDI, M. et al. Relationships between disability, quality of life and prevalence of non motor symptoms in Parkinson's disease. Parkinsonism and

Related Disorders 18; 35 - 39, 2012.

25. LINDE, K. et al. Systematic reviews of complementary therapies - an annotated bibliography. Part I: Acupuncture. BMC Complementary alternative Medicine 1:3, 2001.

26. LITSCHER, G. Effects of acupressure, manual acupuncture and Laserneedle acupuncture on EEG bispectral index and spectral edge frequency in healthy volunteers. European Journal of Anesthesiology 21:13-19, 2004.

27. LIU, P. et al. Power estimation predicts specific function action of acupuncture: an fMRI study. Magnetic Resonance Imaging 29; 1059-1064, 2011.

28. MARTINS, E.I.S; GARCIA, E.G. Pontos de acupuntura - Guia ilustrado de referência. Editora Roca, 2003.

29. MELLO, M.P.B.; BOTELHO, A.C.G. Correlação das escalas de avaliação utilizadas na doença de Parkinson com aplicabilidade na fisioterapia. Fisioter.Mov. 23(1); 121-127, 2010.

30. MELZACK, R.; WALL, P. D. Acupuncture and transcutaneous electrical nerve stimulation. Postgraduate Medical Journal 60, 893-896, 1984.

31. MILLER, D.B; O'CALLAGHAN, J.P. Biomarkers of Parkinson's disease: Present and future. Metabolism Clinical and Experimental 6 4; 40 - 4 6, 2015.

32. MOFFET, H. H. How might acupuncture work? A systematic review of physiologic rationales from clinical trials. BMC Complementary and alternative medice 6(25) 2006.

33. MUCHTADI, F. I. et al Time-frequency analysis of EEG signals response due to simple acupuncture stimulation. World Academy of Science, Engineering and Technology 50, 2009. 
34. NAM KIM, S. et al. Combined treatment withacupuncture reduces effective dose and alleviates adverse effect of L-dopa by normalizing Parkinson's disease-induced neurochemical imbalance. Brain Res. 28(1544) 33-44, 2014.

35. PARK, J. Y. et al. p53 signaling mediates acupuncture - induced neuroprotection in Parkinson's disease. Biochemical and Biophysical Research Communications.460; 772 - 779, 2015.

36. QIAO-FENG, W. et al. A ${ }^{1} \mathrm{H}$ NMR- based metabonomicsdudy on the SAMP8 and SAMR1 mice and the effect of electro-acupuncture. Experimental Gerontology 46: 787-793, 2011.

37. RUI, G. et al. High frequency electro-acupuncture enhances striatum DAT and D1 receptor expression, but decreases D2 receptor level in 6-OHDA lesioned rats. Behavioural Brain Research 237; 263- 269, 2013.

38. SAIDAH, R. et al. Use of acupuncture after arthroscopic knee surgery and its relationshipto pain, physical activity and need of walking aid. Acta ortop. bras. 11 (1) 2003.

39. SCHRAG, A. Quality of life and depression in Parkinson's disease. Journal of the Neurological Sciences 248; 151 - 157, 2006.

40. SOH, S.E., MORRIS,M.E., McGINLEY, J.L..Determinants of healthrelated quality of life in Parkinson's disease: A systematic review. Parkinsonism and Related Disorders. 17; 1-9, 2011.

41. SRBELY, J. Z., LEED,.D.D., LOWERISON, M. Dryneedle stimulation of myofascial trigger points evokes segmental antinociceptive effects. Journal of Rehabilitation Medicine 42(5);463-468, 2010.

42. SUÀREZ, B. G. et al. Neuromodulación acupunctural y regulación nociceptiva. Rev. Habanera cienc. med., 4(12) 2005.

43. SUÀREZ, B. G. et al. Bases neurobiológicas de la acupuntura y la electroacupuntura. Rev. Habanera cienc. med. 3(10) 2004. 
44. SUN, Z. et al. Inhibition of glutamate and acetylcholine release in behavioral improvement induced by electroacupuncture in parkinsonian rats. Neuroscience Letters. 520; 32- 37, 2012.

45. TAKIGUCHI, R.S. et al. Efeito da acupuntura na melhora da dor, sono e qualidade de vida em pacientes fibromialgicos: estudo preliminar. Fisioterapia e Pesquisa v.15 n3. 280-4, 2008.

46. TIAGO, MSF; ALMEIDA, FO; SANTOS, LS, VERONEZI, RJB. Instrumentos de avaliação de qualidade de vida na doença de Parkinson. RevNeurocienc. 18(4):538-543, 2010.

47. TOOSIZADEH, N. et al. Does Integrative Medicine Enhance Balance in Aging Adults? Proof of Concept for the Benefit of Electroacupuncture Therapy in Parkinson's Disease. Gerontology. 61:3-14. 2015.

48. WANG, $\mathrm{H}$. et al Electro-acupuncture stimulation improves spontaneous locomotor hyperactivity im MPTP intoxicated mice. Journal PLoS ONE 8(5), 2013.

49. WANG, $\mathrm{H}$. et al. The antioxidative effect of electro-acupuncture in a mouse model of Parkinson's disease.JournalPLoS ONE 6(11), 2011.

50. WANG, Z. et al. Molecular imaging in tradicional Chinese medicine therapy for neurological disease. BioMed Research International 11 pg, 2013.

51. WATTANATHORN, J; SUTALANGKA, C. Laser acupuncture at HT7 acupoint improves cognitive deficit, neuronal loss, oxidative stress anda functions of cholinergic and dopaminergic systems in animal mmodel of Parkinson's disease. Evidence-Based Complementary and alternative Medicine ID937601, 8pg, 2014.

52. WHITE, A.; CUMMINGS, M. Does acupuncture relieve pain? BMJ 338 $-2760,2009$.

53. YAMAMURA, Yasao. Acupuntura Tradicional- A arte de inserir. Cap 1 Medicina Tradicional Chinesa. 2 edição, São Paulo, Ed. Roca, 2001.

54. YANG, J.L. et al. Neuroprotection effects of retained acupuncture in neurotoxin-induced Parkinson's disease mice. Brain, Behavior and Immunity 25, 1452-1459, 2011. 
55. YEO, S.; CHOI, Y.G.;HONG, Y.M.; LIM, S. Neuroprotective changes of thalamic degeneration-related gene expression by acupuncture in an MPTP mouse model of parkinsonism: Microarray analysis. Gene .515; 329-338, 2013.

56. YEO, S. et al. Acupuncture on GB34 the precentral gyrus and prefrontal cortex in Parkinson's disease. BMC Complementary and Alternative Medicine 14(336) 2014.

57. YEO, S. et al. Neuroprotective changes in degeneration-related gene expression in the substantia nigra following acupuncture in an MPTP mouse model of Parkinsonism: Microarray analysis. Genetics and Molecular Biology. 38 (1); 115127, 2015.

58. YU.Y.; et al. Electroacupuncture Produces the Sustained Motor Improvement in 6 - Hydroxydopamine - Lesioned Mice. PLOS ONEl DOI:10.1371/journal.pone.0149111. February 19, 2016.

59. ZENG, X.H. et al. Acupuncture mechanism and redox equilibrium. Evidence-based Complementary and Alternative Medicine. 7 pag. ID 483294, 2014. 


\section{Anexo 1}

\section{Termo de Consentimento Livre e Esclarecido}

\section{Pesquisa: AÇÃO DA ACUPUNTURA NOS SINTOMAS MOTORES E NÃO MOTORES DA DOENÇA DE PARKINSON.}

Instituição responsável pela pesquisa: Instituto de Psicologia da Universidade de São Paulo, localizado na Avenida Professor Mello de Moraes 1721, Cidade Universitária, São Paulo, SP.

Você está sendo convidado a participar como voluntário de uma pesquisa sobre a ação da acupuntura na Doença de Parkinson. Sua participação não é obrigatória e será mantida em sigilo. Você precisa decidir se quer participar ou não. A qualquer momento durante o decorrer da pesquisa você poderá retirar o seu consentimento, sem qualquer prejuízo a você. Os dados da pesquisa podem vir a ser publicados/divulgados respeitando sua privacidade. Qualquer dúvida pergunte ao pesquisador com quem você está conversando neste momento, ou em qualquer momento durante a pesquisa.

Esta pesquisa tem como objetivo verificar uma possível alteração nas escalas que verificam os sintomas motores e não motores na Doença de Parkinson. Tornando-se importante pois a Doença de Parkinson é um problema de saúde pública sendo a segunda doença neurodegenerativa que pode afetar de $1 \%$ a $5 \%$ dos indivíduos acima de 50 anos, levando a altos custos em tratamentos para alivio ou resolução dos sintomas. A acupuntura realizada somente com as agulhas é utilizada para o tratamento de diversas doenças, sendo uma terapêutica mais barata e podendo ser utilizada como tratamento complementar ao medicamentoso para o alívio dos sintomas motores e não motores.

Sua participação nesta pesquisa consistirá em responder um primeiro questionário para coletar dados pessoais e mensurar pressão arterial e frequência cardíaca, posteriormente serão aplicados outros questionários que irão avaliar e classificar os sintomas motores e não motores da doença. Após será aplicado agulhas de acupuntura nas mãos, nas pernas e na cabeça totalizando 13 agulhas, você sentirá um pequeno desconforto devido a picada, mas que logo desaparece, permanecerá por vinte minutos com as mesmas. Serão realizadas cinco sessões uma vez por semana, podendo ser prorrogado o tratamento para 10 sessões. Após o término das sessões você será submetido aos mesmos questionários aplicados inicialmente logo após o término.

Esta pesquisa não apresenta riscos graves a você, podendo apenas o local que foi inserido as agulhas apresentar vermelhidão após a retirada das mesmas, ou ocorrer pequenos sangramentos, mas a pesquisa será supervisionada por um médico e terá respaldo hospitalar caso precise de qualquer intervenção. Os benefícios serão uma sensação de bem-estar e relaxamento após a sessão de tratamento. Esta pesquisa não trará a você qualquer tipo de custos.

Você receberá uma via deste termo onde consta o telefone, endereço e e-mail do pesquisador responsável, e do Comitê de ética responsável (Av. Professor Mello Moraes, 1721, Bloco G, $2^{\circ}$ andar, sala 27, CEP 05508-030 - Cidade Universitária - São Paulo/SP email: ceph.ip@usp.br - Telefone: (11) 3091-4182) podendo tirar suas dúvidas sobre a pesquisa e sua participação, a qualquer momento. 
$\mathrm{Eu}$

portador do RG número declaro que entendi os objetivos, riscos e benefícios de minha participação na pesquisa e concordo em participar.

Assinatura do voluntário

Pesquisadora responsável: Karen Cristina Pagliuso Wohlers

CREFITO: 74284

Tel:(11)972828353

Email: kcpwfisio@usp.br

São Paulo de de 20 
Anexo 2

Dados Pessoais

Nome:

Idade:

Data de Nascimento: Profissão:

Escolaridade:

Diagnóstico:

Tempo de diagnóstico:

Comorbidades:

Cirurgias:

Outras terapias:

PA: FC:

Medicação: 


\section{Anexo 3}

\section{UPDRS}

\section{EXAME MOTOR}

1. Fala

$0=$ normal.

1= diminuição da expressão, volume e/ou dicção.

$\mathbf{2}=$ comprometimento moderado, fala monótona, mas compreensível.

3= comprometimento grave, difícil compreensão.

4= incompreensível.

\section{Expressão facial}

$\mathbf{0}=$ normal.

1= hipomimia mínima.

$\mathbf{2}=$ expressão facial definitivamente anormal, embora em grau leve.

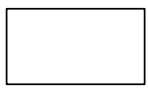

3= hipomimia moderada, lábios caídos/afastados por algum tempo.

4= fácies congelada, lábios constantemente entreabertos $1 \mathrm{~cm}$ ou mais.

3. Tremor de repouso

$\mathbf{0}=$ ausente.

$\mathbf{1 =}$ leve e infrequente.

$\mathbf{2}=$ Baixa amplitude e persistente ou moderada amplitude intermitente.

$\mathbf{3}=$ amplitude moderada e presente a maior parte do tempo.

4= grande amplitude e presente a maior parte do tempo.

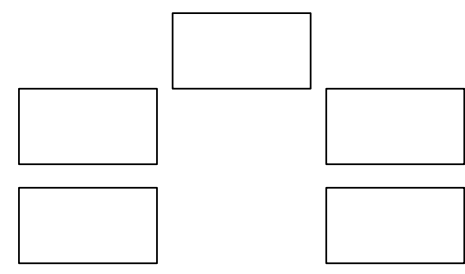

4. Tremor postural ou de ação nas mãos

$\mathbf{0}=$ ausente

$\mathbf{1 =}$ leve, presente com a ação.

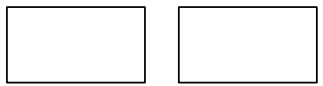

$\mathbf{2}=$ moderado em amplitude, presente com ação.

3= moderado em amplitude, postural e de ação.

4= grande amplitude, interferindo com a alimentação.

5. Rigidez (movimento passivo das grandes articulações, com paciente sentado e relaxado, ig roda denteada)

$\mathbf{0}=$ ausente

1= Leve ou detectável somente quando ativado por movimentos em espelho de outros.

$\mathbf{2}=$ leve a moderado.

3= marcante, mas pode realizar o movimento completo da articulação.

4=grave. Movimento completo da articulação ocorre com grande dificuldade.

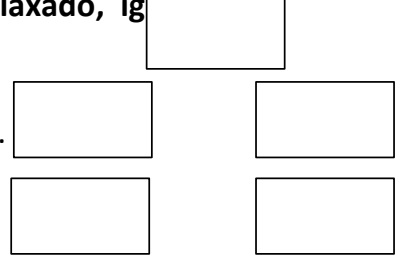

6. Bater dedos continuamente - polegar no indicador em seqüências rápidas com a maior amplitude possível, uma mão de cada vez.

$\mathbf{0}=$ normal

1= leve lentidão e/ou redução da amplitude.

$\mathbf{2}=$ comprometimento moderado. Fadiga precoce.

3= comprometimento grave. Hesitação freqüente para iniciar o movimento ou paradas constantes.

4= Enorme dificuldade, quase impossibilidade de realizar a tarefa.

7. Movimentos das mãos (abrir e fechar as mãos em movimentos rápidos e sucessivos e com a maior amplitude possível, uma mão de cada vez).

$\mathbf{0}=$ normal

$1=$ leve lentidão e/ou redução da amplitude.
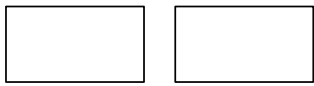
$\mathbf{2}=$ comprometimento moderado. Fadiga precoce.

3= comprometimento grave. Hesitação freqüente para iniciar o movimento ou paradas constantes.

4= Enorme dificuldade, quase impossibilidade de realizar a tarefa.

8. Movimentos rápidos alternados das mãos (pronação e supinação das mãos, horizontal ou verticalmente, com a maior amplitude possível, as duas mãos simultaneamente).

$\mathbf{0}=$ normal

1= leve lentidão e/ou redução da amplitude.

$\mathbf{2}=$ comprometimento moderado. Fadiga precoce.

3= comprometimento grave. Hesitação freqüente para iniciar o movimento ou paradas constantes.

4= Enorme dificuldade, quase impossibilidade de realizar a tarefa.

9. Agilidade da perna (bater o calcanhar no chão em sucessões rápidas, levantando toda a perna, a amplitude do movimento deve ser de cerca de 3 polegadas $\pm \pm 7,5 \mathrm{~cm}$ ).

$\mathbf{0}=$ normal

$\mathbf{1 =}$ leve lentidão e/ou redução da amplitude.

$\mathbf{2}=$ comprometimento moderado. Fadiga precoce.

3= comprometimento grave. Hesitação freqüente para iniciar o movimento ou paradas constantes.

4= Enorme dificuldade, quase impossibilidade de realizar a tarefa.

10. Levantar da cadeira com braços cruzados em frente ao peito.

$\mathbf{0}=$ normal

$\mathbf{1 =}$ lento ou pode precisar de mais de uma tentativa

$\mathbf{2}=$ levanta-se apoiando nos braços da cadeira.

3= tende a cair para trás, pode tentar mais de uma vez, mas consegue levantar

4= incapaz de levantar-se sem ajuda.

\section{Postura}

$\mathbf{0}=$ normal em posição ereta.

$\mathbf{1 =}$ levemente curvado, poderia ser normal para um idoso.

$\mathbf{2}=$ moderadamente curvado, definitivamente anormal Pode inclinar-se um pouco para os lados.

3= acentuadamente curvado para frente com cifose e/ou inclinação moderada para um dos lados.

4=fletido com anormalidade acentuada da postura.

\section{Marcha}

$0=$ normal

1= anda lentamente, pode arrastar os pés com pequenas passadas, mas não há festinação ou propulsão.

$\mathbf{2 =}$ anda com dificuldade, mas precisa de pouca ajuda ou nenhuma. Pode apresentar alguma festinação, passos curtos, ou propulsão.

$3=$ comprometimento grave da marcha, necessitando de ajuda.

4= não consegue andar sozinho, mesmo com ajuda.

13. Estabilidade postural (respostas ao deslocamento súbito para trás, puxando os ombros, com paciente ereto, de olhos abertos, pés separados, informado a respeito do teste)

$\mathbf{0}=$ normal

$1=$ retropulsão, mas se recupera sem ajuda.

$\mathbf{2}=$ ausência de respostas posturais, cairia se não fosse auxiliado pelo examinador.

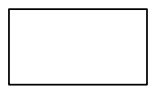

3= muito instável, perde o equilíbrio espontaneamente.

4= incapaz de ficar em pé sem apoio.

14. Bradicinesia e hipocinesia corporal (combinação de hesitação, diminuição do balançar dos braços, pobreza e pequena amplitude de movimentos em geral)

$\mathbf{0}=$ nenhum.

1= lentidão mínima. Poderia ser normal em algumas pessoas. Possível redução na amplitude. 
$\mathbf{2 =}$ Pobreza de movimento e lentidão leves, mas definitivamente anormais.

3= lentidão moderada. Pobreza de movimento, com pequena amplitude.

4= lentidão acentuada. 


\section{Anexo 4}

\section{ESCALA DE HOEHN \& YAHR MODIFICADA}

ESTÁGIO 0 - Sem sinais da doença

ESTÁGIO 1 - Doença unilateral

ESTÁGIO 1,5- Doença unilateral mais envolvimento axial

ESTÁGIO 2 - Doença bilateral, sem problemas de equilíbrio

ESTÁGIO 2,5 - Doença discreta bilateral; recuperação no teste de instabilidade postural

ESTÁGIO 3 - Doença discreta ou moderada e bilateral; alguma instabilidade postural, fisicamente independente

ESTÁGIO 4 - Incapacidade intensa; consegue andar e ficar em pé sem assistência

ESTÁGIO 5 - Restrito à cadeira de rodas ou no leito 


\section{Anexo 5}

\section{PDQ39 (Questionário sobre a Doenca de Parkinson)}

- Devido a doença de Parkinson, quantas vezes, durante o mês passado você...

\section{MOBILIDADE}

1- Teve dificuldade para realizar atividades de lazer as quais gosta?

NUNCA RARAMENTE ALGUMAS VEZES FREQUENTEMENTE SEMPRE

2- Teve dificuldade para cuidar da casa?

NUNCA RARAMENTE ALGUMAS VEZES FREQUENTEMENTE SEMPRE

3- Teve dificuldade para carregar sacolas?

NUNCA RARAMENTE ALGUMAS VEZES FREQUENTEMENTE SEMPRE

4- Teve problemas para andar aproximadamente $1 \mathrm{~km}$ ?

NUNCA RARAMENTE ALGUMAS VEZES FREQUENTEMENTE SEMPRE

5- Teve problemas para andar aproximadamente $100 \mathrm{~m}$ ?

NUNCA RARAMENTE ALGUMAS VEZES FREQUENTEMENTE SEMPRE

6- Teve problemas para andar pela casa com a facilidade que gostaria?

NUNCA RARAMENTE ALGUMAS VEZES FREQUENTEMENTE SEMPRE 
7- Teve dificuldade para andar em lugares públicos?

NUNCA RARAMENTE ALGUMAS VEZES FREQUENTEMENTE SEMPRE

8- Precisou de alguma pessoa para acompanhá-lo ao sair de casa?

NUNCA RARAMENTE ALGUMAS VEZES FREQUENTEMENTE SEMPRE

9- Teve medo ou preocupação de cair em público?

NUNCA RARAMENTE ALGUMAS VEZES FREQUENTEMENTE SEMPRE

10- Ficou em casa mais tempo que gostaria?

NUNCA RARAMENTE ALGUMAS VEZES FREQUENTEMENTE SEMPRE

\section{ATIVIDADE DE VIDA DIÁRIA}

11- Teve dificuldade para tomar banho?

NUNCA RARAMENTE ALGUMAS VEZES FREQUENTEMENTE SEMPRE

12- Teve dificuldade para vestir-se?

NUNCA RARAMENTE ALGUMAS VEZES FREQUENTEMENTE SEMPRE

13- Teve dificuldade com botões ou cadarços?

NUNCA RARAMENTE ALGUMAS VEZES FREQUENTEMENTE SEMPRE 
14- Teve dificuldade para escrever claramente?

NUNCA RARAMENTE ALGUMAS VEZES FREQUENTEMENTE SEMPRE

15- Teve dificuldade para cortar a comida?

NUNCA RARAMENTE ALGUMAS VEZES FREQUENTEMENTE SEMPRE

16- Teve dificuldade para beber sem derramar?

NUNCA RARAMENTE ALGUMAS VEZES FREQUENTEMENTE SEMPRE

\section{BEM-ESTAR EMOCIONAL}

17- Sentiu-se depressivo?

NUNCA RARAMENTE ALGUMAS VEZES FREQUENTEMENTE SEMPRE

18- Sentiu-se isolado e sozinho?

NUNCA RARAMENTE ALGUMAS VEZES FREQUENTEMENTE SEMPRE

19- Sentiu-se triste ou chorou?

NUNCA RARAMENTE ALGUMAS VEZES FREQUENTEMENTE SEMPRE 
20- Sentiu-se magoado?

NUNCA RARAMENTE ALGUMAS VEZES FREQUENTEMENTE SEMPRE

21- Sentiu-se ansioso?

NUNCA RARAMENTE ALGUMAS VEZES FREQUENTEMENTE SEMPRE

22- Sentiu-se preocupado com o futuro?

NUNCA RARAMENTE ALGUMAS VEZES FREQUENTEMENTE SEMPRE

\section{ESTIGMA}

23- Sentiu que tinha que esconder a doença para outras pessoas?

NUNCA RARAMENTE ALGUMAS VEZES FREQUENTEMENTE SEMPRE

24- Evitou situações que envolviam comer ou beber em público?

NUNCA RARAMENTE ALGUMAS VEZES FREQUENTEMENTE SEMPRE

25- Sentiu-se envergonhado em público?

NUNCA RARAMENTE ALGUMAS VEZES FREQUENTEMENTE SEMPRE

26- Sentiu-se preocupado com a reação de outras pessoas em relação à você?

NUNCA RARAMENTE ALGUMAS VEZES FREQUENTEMENTE SEMPRE 


\section{SUPORTE SOCIAL}

27- Teve problemas no relacionamento com pessoas próximas?

NUNCA RARAMENTE ALGUMAS VEZES FREQUENTEMENTE SEMPRE

28- Recebeu apoio que precisava do seu conjugue ou parceiro?

NUNCA RARAMENTE ALGUMAS VEZES FREQUENTEMENTE SEMPRE

29- Recebeu apoio que precisava da família e amigos íntimos?

NUNCA RARAMENTE ALGUMAS VEZES FREQUENTEMENTE SEMPRE

\section{COGNICÃO}

30- Adormeceu inesperadamente durante o dia?

NUNCA RARAMENTE ALGUMAS VEZES FREQUENTEMENTE SEMPRE

31- Teve problemas de concentração?

NUNCA RARAMENTE ALGUMAS VEZES FREQUENTEMENTE SEMPRE

32- Teve falta de memória?

NUNCA RARAMENTE ALGUMAS VEZES FREQUENTEMENTE SEMPRE

33- Teve pesadelos ou alucinações?

NUNCA RARAMENTE ALGUMAS VEZES FREQUENTEMENTE SEMPRE 


\section{COMUNICACÃO}

34- Teve dificuldade para falar?

NUNCA RARAMENTE ALGUMAS VEZES FREQUENTEMENTE SEMPRE

35- Sentiu que não podia comunicar-se efetivamente?

NUNCA RARAMENTE ALGUMAS VEZES FREQUENTEMENTE SEMPRE

36- Sentiu-se ignorado pelas pessoas?

NUNCA RARAMENTE ALGUMAS VEZES FREQUENTEMENTE SEMPRE
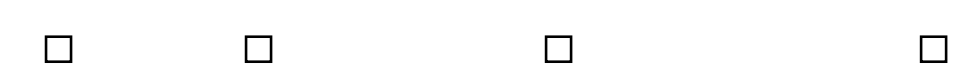

\section{DESCONFORTO CORPORAL}

37- Teve cãibras musculares doloridas ou espasmos?

NUNCA RARAMENTE ALGUMAS VEZES FREQUENTEMENTE SEMPRE

38- Teve dores nas articulações ou no corpo?

NUNCA RARAMENTE ALGUMAS VEZES FREQUENTEMENTE SEMPRE

39- Sentiu-se desconfortável no frio ou no calor?

NUNCA RARAMENTE ALGUMAS VEZES FREQUENTEMENTE SEMPRE 


\title{
Anexo 6
}

\section{Non-Motor Symptom assessment scale for Parkinson's Disease}

\author{
Patient ID Ne:
}

Initials:

Ane:

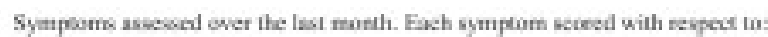

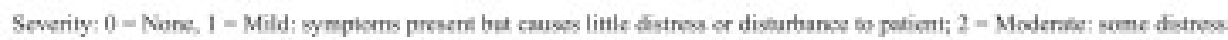

ar Asturbence to patienc 3 - Severe. major source of dstress or dissurbanoe to posictit.

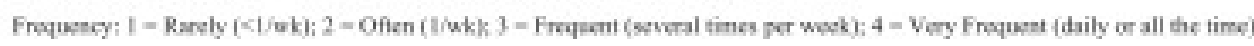

Domains will be weight differentially. Yes/ No answers are not included in final frequency $\mathrm{x}$ severity calculation. (Bocketiod test in questions within the scak is included as an explanalory aid).

\section{Domain 1: Cardievascular including falls}

Sourity Erequensy Excumeno

1. Does the patient experience light-headedness, diexiness, weakness ce standing from sitting or lying position?

2. Does the patient fall because of fainting of blacking cur? SCORE:

\section{Domain 2: Sleep'fatigue}

3. Does the patient dose of or fall asleep unintemtionsllly during daytime setivities? (For example, during coeversation, during mealtimes, of uhile wasching television of roling),

4. Does fatigue (tiredness) or lack of energy (not slowness) limit the patient's daytime activities?

5. Does the patient have difficultics falling or staying asleep?

6. Does the parient experience an urge to move the legs ar restleseness in legs that improves with movement when heishe is sitting of lying down inactive?

SCORE:

\section{Domain 3: Mood/Cognition}

7. Has the patient loost interest in his/her surroundings?

8. Has the patient lost interest in doing things or lack motivation to start new activities?

9. Does the parient feel nervous, worried of frighened for no apparent reasen?

10. Doss the patient secm sad or depressed or has heishe reported such foclings?

11. Does the patient have flat moods without the normal "highs" and "lous"?

12. Does the patient have difficulty in experiensing pleasure from their usual activities of report that they lack pleasure?

SCORE:

Domain 4: Perceptual problems/hallucinations

13. Does the patient indicase that hoshe sees things that are not there?

14. Doss the patient have beliefs that you know are not truk? (For easmple, about being hamed, being robbed or being unfaithful)

15. Does the patient experience double vision?

(2 separate real objects and not blurred vision)

SCORE:
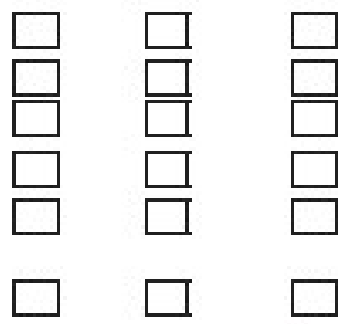

Sexrity

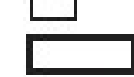


16. Does the patient have problems sustaining concentration during activities? (For example, reading or having a coeversation)

17. Does the patient forget things that heishe has been told a short time ago or events that happened in the last fer days?

18. Does the patient forpet to do things?

(For example, take tablets or turn off domestic appliances?

SCORE:

\section{Domain 6: Gastrointestinal tract}

19. Does the patient dribble saliva during the day?

20. Does the patient having difficulty swallowing?

21. Does the patien suffer from constipation?

(Bowel action less than three times weekly)

SCORE:

\section{Domain 7: Urimary}

22. Does the patient have difficulty holding urine? (Urgency)

23. Does the patient have to void within 2 hours of last woiding? (Frequency)

24. Does the patient have to get up regularly at night to pass urine? (Nocturia)

SCORE:

\section{Demain 8: Sexual function}

25. Does the patient have altered interest in $\mathrm{xex}$ ?

(Very much increased or decreased, please underline)

26. Does the potient have problems having sex?

SCORE:

\section{Domain 9: Mliscellaneous}

27. Does the patient suffer from pain not explained by ceher knomen conditions? (ls it related to intake of drugs and is it relicved by antiparkineon drugs?)

28. Does the potient report a clange in ability wo taste of smell?

29. Does the patient repart a recent change in weight (not related to dieting)?

10. Does the putient experience excessive sweating? (not related to hot weather)

SCORE:

\section{IOTALSCORE:}

Developed by the Intemational Parkinson's Disease Non- Mobor Group.

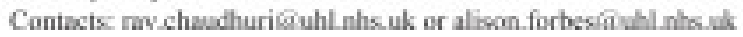




\section{Anexo 7}

\section{MINI EXAME DO ESTADO MENTAL}

Orientação Temporal Espacial - questão 2.a até 2.j pontuando 1 para cada resposta correta, máximo de 10 pontos.

Registros - questão 3.1 até 3.d pontuação máxima de 3 pontos.

Atenção e cálculo - questão 4.1 até 4 .f pontuação máxima 5 pontos. Lembrança ou memória de evocação - 5.a até 5.d pontuação máxima 3 pontos. Linguagem - questão 5 até questão 10, pontuação máxima 9 pontos.

Pontuações máximas

Pontuações

máximas

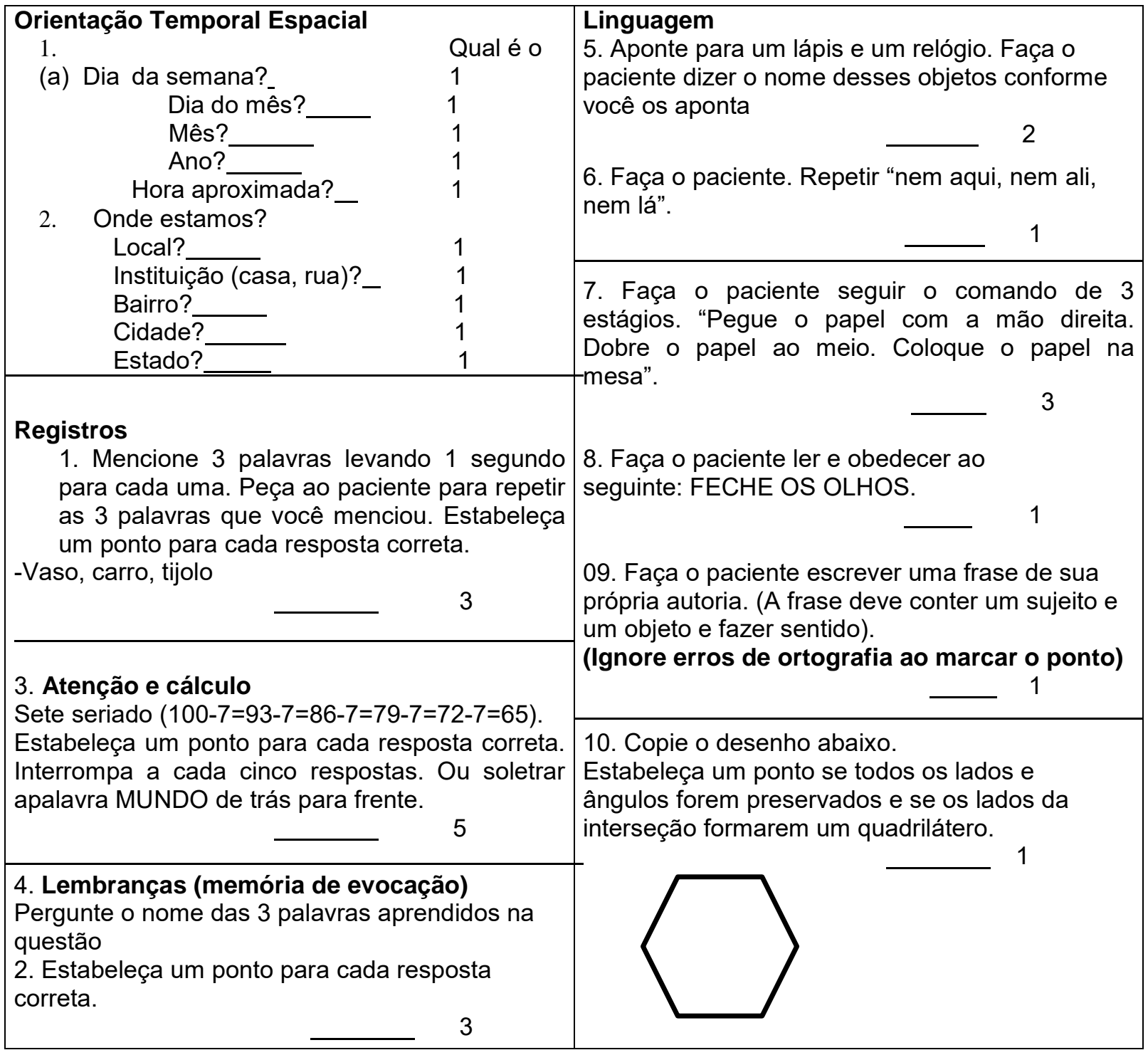


Pontos de corte - MEEM Brucki et al. (2003) 20

pontos para analfabetos

25 pontos para idosos com um a quatro anos de estudo

26,5 pontos para idosos com cinco a oito anos de estudo

28 pontos para aqueles com 9 a 11 anos de estudo

29 pontos para aqueles com mais de 11 anos de estudo. 


\section{Anexo 8}

Escala visual Analógica de dor 


\section{Anexo 9}

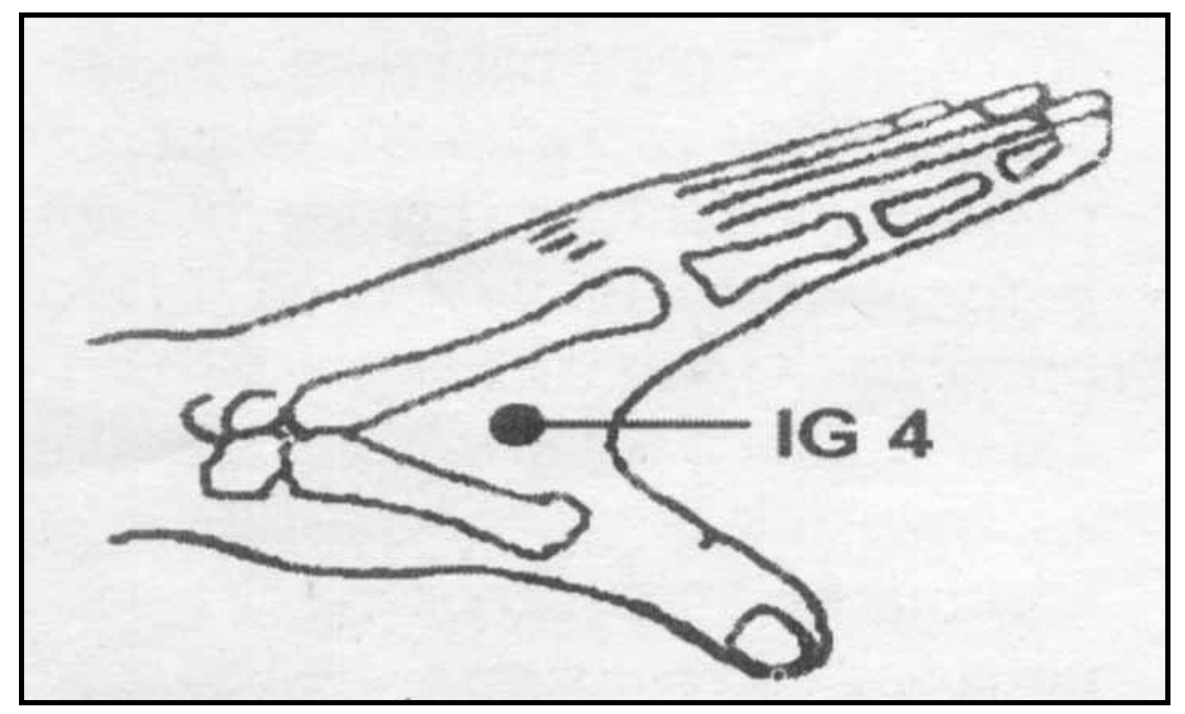

Figura 2: Localização do ponto de acupuntura IG4

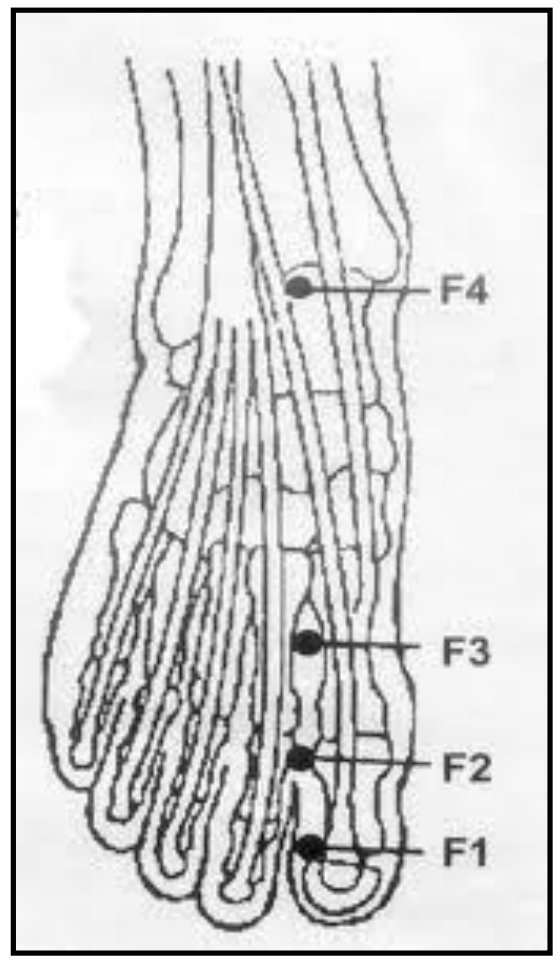

Figura 3: Localização do ponto de acupuntura F3 


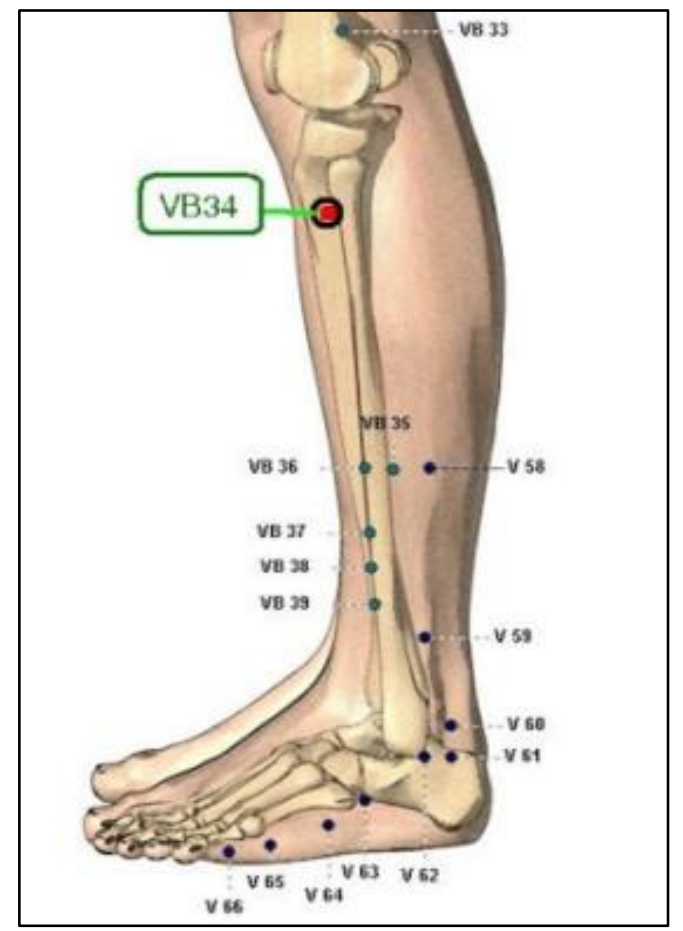

Figura 4: Localização do ponto de acupuntura VB34

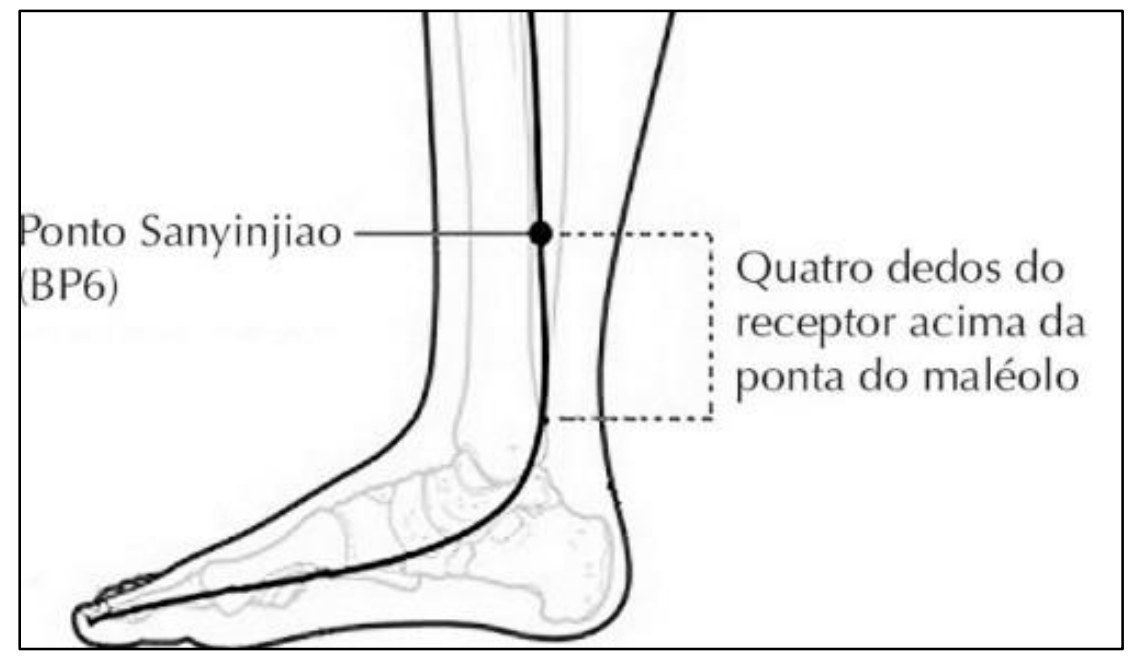

Figura 5: Localização do ponto de acupuntura BP6 


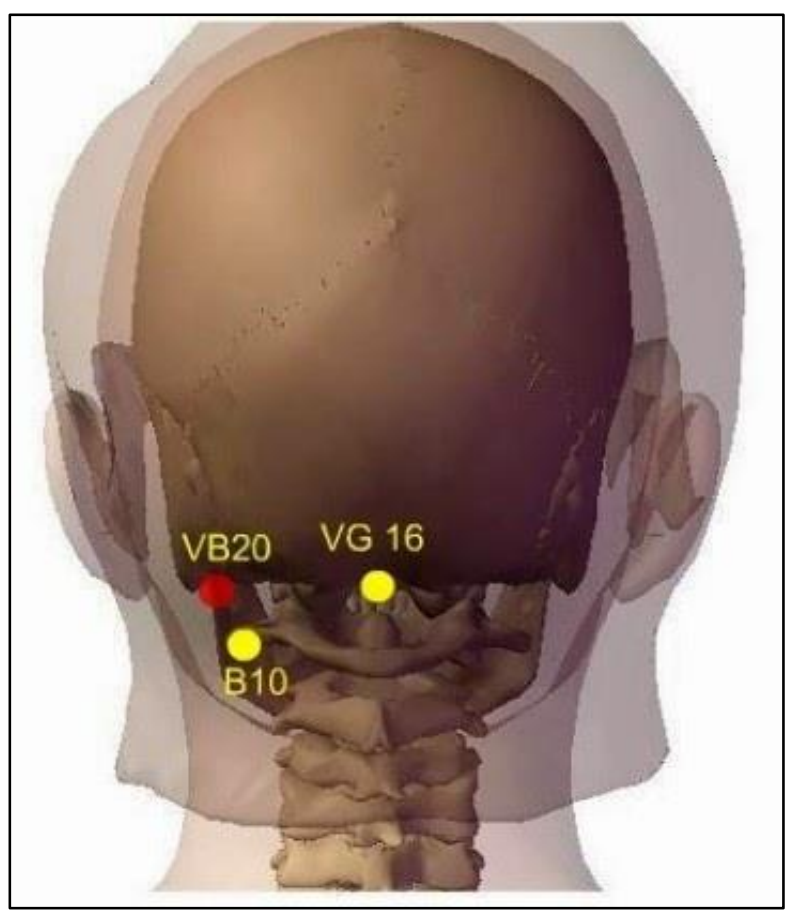

Figura 6: Localização do ponto de acupuntura VB20

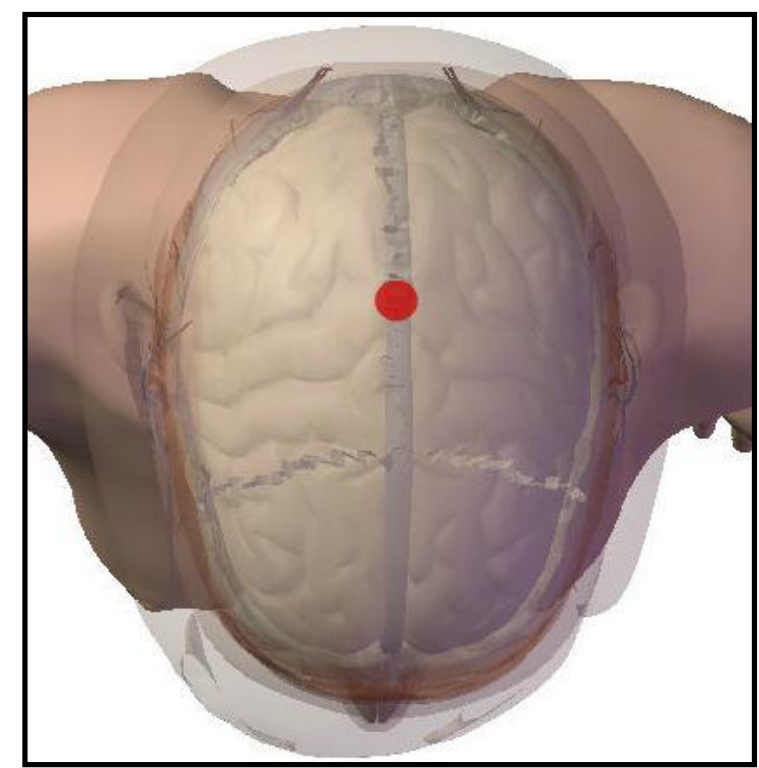

Figura 7: localização do ponto de acupuntura VG20 